\title{
MEDIA PEMBELAJARAN ANAK USIA DINI
}

Guslinda, S.Pd, M.Pd

Dr. Rita Kurnia, M.Ed

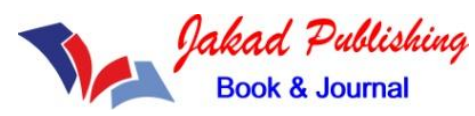

2018 
PERPUSTAKAAN NASIONAL REPUBLIK INDONESIA KATALOG DALAM TERBITAN ( KDT )

\title{
MEDIA PEMBELAJARAN ANAK USIA DINI
}

Penulis

Guslinda, S.Pd, M.Pd dan Dr. Rita Kurnia, M.Ed

\author{
Desain Cover \\ Defri Kurniawan \\ Layout \\ Lutfiah, S.H.I. \\ Setyaningrum
}

Copyright ( 92018 Jakad Publishing

Surabaya

Diterbitkan \& Dicetak Oleh

CV. Jakad Publishing Surabaya 2018

Jl. Gayung Kebon Sari I No. 1 Surabaya

Telp. : 081234408577

E-mail : jakadmedia@gmail.com

ISBN : 978-602-52855-3-0

Hak cipta dilindungi oleh Undang-undang

Ketentuan Pidana Pasal 112 - 119

Undang-undang Nomor 28 Tahun 2014

Tentang Hak Cipta.

Dilarang keras menerjemahkan, memfotokopi, atau memperbanyak sebagian atau seluruh isi buku ini tanpa izin tertulis dari penerbit 


\section{KATA PENGANTAR}

Alhamdulillah Puji syukur kami ucapkan kehadirat Allah SWT atas berkat Rahmat dan Karunia-Nya, sehingga penulisan buku ini dengan judul " Media Pembelajaran Anak Usia Dini" dapat diselesaikan. Sejalan dengan perkembangan dan kemajuan zaman, menuntut guru untuk kreatif dalam pemberian pembelajaran, khususnya pembelajaran anak usia dini. Guru kreatif adalah guru yang mampu memfasilitasi anak dengan berbagai media, sumber belajar, atau APE. Konsep belajar pada anak usia dini adalah belajar sambil bermain melalui aktifitas alami yang dilakukan anak usia dini. Untuk bisa memfasilitasi anak dalam bermain tentu diperlukan media, sumber belajar atau APE.

Dalam buku ini berisi pembahasan tentang pengembangan media, sumber belajar dan juga APE yang dilengkapi dengan beberapa contoh untuk membuka ide dalam pengembangan media, sumber belajar dan APE untuk anak usia dini. Harapan Penulis semoga buku ini berguna sebagai sumber dan rujukan dalam pengembangan media, sumber belajar dan APE bagi pendidik PAUD (TK, KB, TPA) dan mahasiswa PG PAUD atau PIAUD.

Penulis menyadari bahwa karya ini masih ada kekurangan, untuk itu penulis mengharapkan kritik dan saran yang sifatnya membangun. Untuk itu penulis sangat berterima kasih apabila saran dan koreksinya disampaikan kepada penulis untuk penyempurnaan dari karya tulis ini.

Pekanbaru, September 2018

Penulis 


\section{DAFTAR ISI}

Halaman Judul..............................................................................

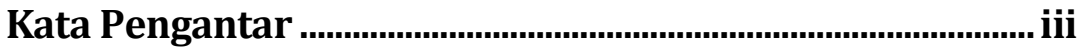

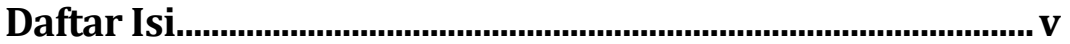

BAB I : KONSEP MEDIA PEMBELAJARAN .............................. 1

A. Pengertian Media Pembelajaran Anak Usia Dini.....................................................................................1

B. Fungsi Media Pembelajaran Anak Usia Dini ............5

C. Pengelompokan Media Pembelajaran .........................12

1. Media Visual ................................................................ 14

2. Media Audio...................................................................... 15

3. Media Audio Visual ....................................................15

BAB II : SUMBER BELAJAR UNTUK ANAK USIA DINI ...........

A. Pengertian Sumber Belajar............................................19

B. Fungsi dan Manfaat Sumber Belajar..........................20

C. Klasifikasi Sumber Belajar ............................................22

BAB III : ALAT PERMAINAN EDUKATIF UNTUK ANAK

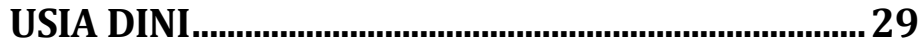

A. Pengertian Alat Permainan Edukatif (APE)..........29

B. Ciri-ciri Alat Permainan Edukatif (APE) .................30

C. Jenis Alat Permainan Edukatif (APE) ........................34

1. APE Untuk Kemampuan Bahasa.........................35

2. Ape Ciptaan Montesori ...........................................37

3. APE Geogle Cruissenaire........................................38

4. APE Ciptaan Froebe.................................................39

BAB IV : PENGEMBANGAN MEDIA, SUMBER BELAJAR DAN

APE UNTUK ANAK USIA DINI ..................................... 41

A. Media, Sumber Belajar, dan APE Berbasis

Budaya 41

1. Aspek Perkembangan Anak Usia Dini Dalam 
Budaya Melayu 43

2. Pendekatan dan Metode Pendidikan Budaya Melayu Pada Anak Usia Dini 44

3. Pengembangan Media Pembelajaran Berbasis Budaya 52

B. Media, Sumber Belajar dan APE Berbasis Lingkungan 64

1. Lingkungan Sosial 65

2. Lingkungan Alam. 66

3. Lingkungan Buatan................................................. 66

C. Media, Sumber Belajar dan APE berbasis Tema dan Aspek Perkembangan Anak 67

1. Pengembangan Media, Sumber Belajar, Dan APE Mengacu pada Tema 70

2. Pengembangan Media, Sumber Belajar, dan APE Mengacu pada Aspek Perkembangan Anak 75

BAB V : MEDIA PENGEMBANGAN SENI ANAK USIA DINI ...89

A. Pengertian Seni............................................................. 89

B. Pembelajaran Seni di PAUD/TK ……………........... 94

C. Peraturan Menteri Pendidikan dan Kebudayaan RI No. 137 Tahun 2014 tentang Standar PenDidikan Anak Usia Dini 95

D. Implementasi Pendidikan Seni Anak Usia Dini. 97

DAFTAR PUSTAKA 


\section{BAB I \\ KONSEP MEDIA PEMBELAJARAN}

\section{A. Pengertian Media Pembelajaran Anak Usia Dini}

Media pembelajaran mempunyai peranan yang penting dalam proses kegiatan belajar mengajar. Dengan adanya media, proses kegiatan belajar mengajar akan semakin dirasakan manfaatnya. Penggunaan media diharapkan akan menumbuhkan dampak positif, seperti munculnya proses pembelajaran yang lebih kondusif, terjadinya umpan balik dalam proses belajar mengajar, dan mencapai hasil yang optimal. Menurut Arsyad (2016), Istilah media berasal dari bahasa latin yang merupakan bentuk jamak dari "medium" yang secara harafiah berarti perantara atau pengantar. Secara umumnya adalah segala sesuatu yang dapat menyalurkan informasi dari sumber informasi kepada penerima informasi. Istilah media dikenal dalam bidang komunikasi. Proses belajar mengajar pada dasarnya juga merupakan proses komunikasi, sehingga media yang digunakan dalam pembelajaran disebut media pembelajaran. Adapun pengertian media pembelajaran menurut para ahli :

1. Menurut Heinich, dkk (dalam Arsyad 2016), media merupakan alat saluran komunikasi. Media berasal dari bahasa Latin dan merupakan bentuk jamak dari kata "medium" yang secara harfiah berarti "perantara" yaitu perantara sumber pesan (a source) dengan penerima pesan (a receiver). Heinich mencontohkan media ini seperti film, televisi, diagram, bahan tercetak (printed materials), komputer, dan instruktur. 
2. Menurut Hairudin, dkk (2008) berpendapat bahwa "segala sesuatu yang dapat menyalurkan informasi dari sumber kepada penerima. Serta untuk mencapai tujuan pembelajaran tertentu yang sudah dirumuskan".

3. Menurut Kamus Besar Bahasa Indonesia (2005), Media adalah berbagai jenis komponen dalam lingkungan anak yang dapat memberikan rangsangan untuk belajar.".

4. Menurut Miarso (2004) berpendapat bahwa "Media pembelajaran adalah segala sesuatu yang digunakan untuk menyalurkan pesan serta dapat merangsang pikiran, perasaan, perhatian, dan kemauan si belajar sehingga dapat mendorong terjadinya proses belajar".

5. Menurut Dadan Djuanda (2006) mengatakan "Media pembelajaran adalah segala sesuatu yang dapat digunakan untuk menyalurkan pesan dari pengirim ke penerima sehingga dapat digunakan menyalurkan pesan dari pengirim ke penerima sehingga dapat merangsang pikiran, perasaan, serta perhatian murid agar proses belajar terjadi".

6. Menurut Rita (2009) berpendapat bahwa "Media (alat) dalam pengajaran melalui simulasi dari inti pengajaran yang disampaikan baik secara deskriptif maupun demonstrasi yang tentunya ini menandakan pada fungsinya sebagai penyampai pesan, serta dalam konteks media pembelajaran bagi anak usia dini, media merupakan segala alat fisik yang dapat menyajikan pesan serta merangsang anak didik untuk belajar".

7. Degeng, 1993, (Trianto, 2011, media pembelajaran adalah komponen strategi penyampaian yang dapat dimuati pesan yang akan disampaikan kepada sibelajar, apakah itu orang tua, alat, atau bahan. 
Jadi, kesimpulan dari beberapa pendapat tentang media pembelajaran yaitu suatu bentuk peralatan, metode, atau teknik yang digunakan dalam menyalurkan pesan, membantu mempertegas bahan pelajaran, sehingga dapat mebangkitkan minat dan motivasi murid atau anak didik dalam mengikuti proses belajar mengajar. Dalam hal ini penerima pesan adalah murid, sebaiknya dalam setiap pembelajaran tidak lepas dari penggunaan media. Media pembelajaran sebenarnya alat bantu yang berguna bagi pendidik dalam membantu tugas kependidikannya. Secara umum, media pembelajran berguna untuk menuntun dan mengarahkan murid untuk memperoleh pengalaman belajar, Pengalaman belajar yang diperoleh murid tergantung adanya interaksi murid dengan media. Dengan adanya penggunaan media pembelajaran yang sesuai dengan tujuan pembelajaran, tentunya akan meningkatkan hasil belajar. Sejalan dengan teori "Cone Experience" yang dikemukakan oleh Edgare Dale, yang menjadi pokok penggunaan dalam pembelajaran. (dalam Indriana, 2011). Inti dari teori ini adalah pengetahuan akan semakin abstrak apabila pesan hanya disampaikan menggunakan kata verbal. Murid akan memahami pengetahuan dalam bentuk kata, tanpa mengetahui apa yang terkandung dalam pengetahuan tersebut. Sebaliknya, semakin ke bawah dalam gambar di atas, murid akan semakin konkret dan tidak salah persepsi. Makanya, agar murid memiliki pengalaman yang konkret salah satu caranya adalah penggunaan media pembelajaran dalam proses belajar mengajar.

Usaha penggunaan media sebagai alat bantu dalam pembelajaran, seorang ahli pendidikan Edgar Dale (Arsyad 2016) membuat klasifikasi pengalaman belajar menurut tingkat dari yang paling konkret ke yang paling abstrak. Klasifikasi 
tersebut kemudian dikenal dengan Hama kerucut pengalaman atau The Cone of Experience. Kerucut pengalaman Edgar Dale ini mengklasifikasikan media berdasarkan pengalaman belajar yang akan diperoleh oleh anak didik, mulai dari pengalaman belajar langsung/konkret dan pengalaman belajar yang bersifat tidak langsung/abstrak. Sebagaimana Dadan (2009), mengatakan bahwa penggunaan media pembelajaran sering kali menggunakan prisip kerucut pengalaman.

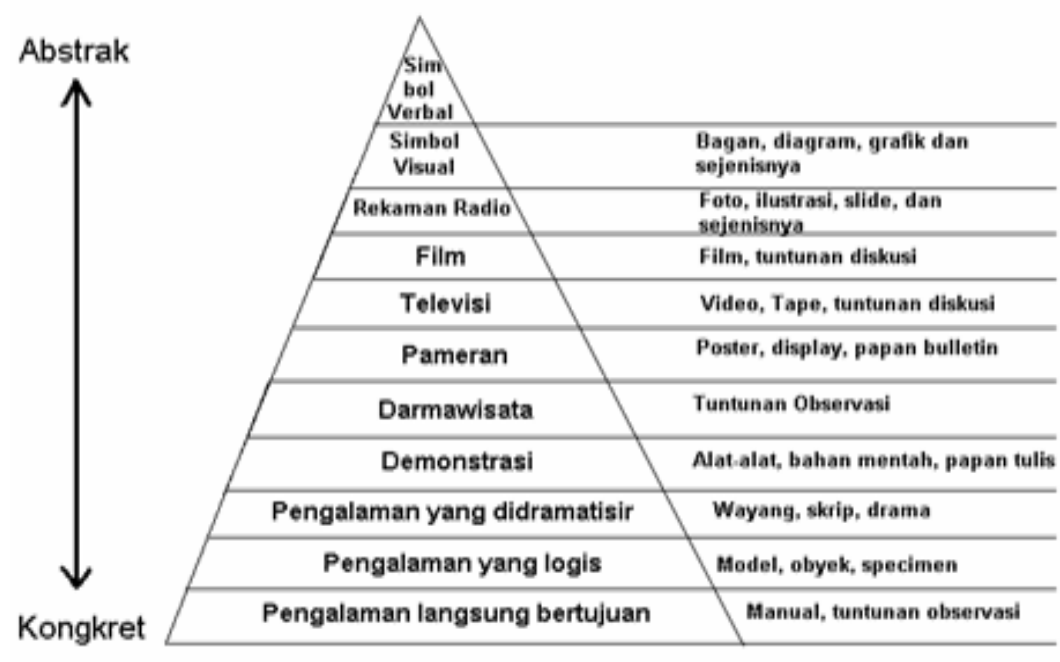

Gambar: 1.1

Kerucut Pengalaman Edgar Dale (Dadan, 2009)

Kerucut pemgalaman Edgar Dale ini, menunjukkan bahwa informasi yang diperoleh melalui pengalaman langsung yang berada pada dasar kerucut mampu menyajikan pengalaman belajar secara lebih konkret. Semakin menuju ke puncak kerucut, penggunaan media semakin memberikan pengalaman belajar yang bersifat abstrak Dengan demikian jika pembelajaran lebih menginginkan pengalaman belajar yang 
lebih konkret dan kaya, maka gunakanlah media-media yang berada pada sekitar bagian dasar pada kerucut pengalaman Edgar Dale tersebut.

\section{B. Fungsi Media Pembelajaran Anak Usia Dini}

Cara berfikir anak usia dini sangat berbeda dengan cara berfikir orang dewasa. Cara berfikir anak usia dini kadang kala tidak masuk akal dan membimbingungkan bagi orang dewasa. Anak akan dapat berfikir secara bersamaan walaupun yang dipikirkannya itu tidak ada berhubungan. menurut Piaget (1972), anak usia dini berada pada praoperasional yaitu usia 26 tahun, dimana anak sudah mulai menggunakan simbol-simbol untuk mempresentasi dunia (lingkungan). Suryanto (2005), mengatakan bahwa perkembangan anak usia dini pada tahap ini anak belajar terbaik melalui kehadiran benda-benda. Anak akan berfikir berdasarkan pada penggalaman akan bendabenda konkret. Untuk memfasilitasi perkembangan tersebut maka dalam pembelajaran dapat dilakukan dengan penggunaan media pembelajaran.

Media selain dapat digunakan untuk mengatarkan pembelajaran secara utuh juga dapat dimanfaatkan untuk menyampaikan bagian tertentu dari kegiatan pembelajaran, memberikan peguatan maupun motivasi. Kembali kepada arti penting media dalam proses belajar mengajar yang dapat mengantarkan kepada tujuan pendidikan, maka berikut ini akan diuraikan berbagai peranan media dalam proses belajar mengajar Hamalik, (dalam Sadiman, 2003).

1. Memperjelas Penyajian Pesan dan Mengurangi Verbalitas

Sesuai dengan karakteristik dari media, maka penggunaan media dapat membantu manusia mengatasi sedikit banyak keterbatasan indera manusia sehingga pesan yang di- 
sampaikan menjadi jelas. Penggunaan media dapat mengurangi verbalitas karena media dapat mendorong anak untuk aktif berperan serta dalam proses belajar mengajar, sehingga informasi yang diterima oleh anak didik tidak hanya dari guru saja tetapi anak didik juga turut aktif mencari dan mendapatkan informasi pembelajaran tersebut.

2. Memperdalam Pemahaman Anak Didik Terhadap Materi Pelajaran

Dengan penggunaan media dalam belajar akan ada kejelasan informasi/pesan tentang materi pelajaran yang diterima anak didik. Di samping itu, melalui media peran aktif anak didik dapat digerakkan untuk memperoleh pengetahuan tentang materi pelajaran, maka hal itu secara otomatis akan memperdalam pemahaman anak didik.

3. Memperagakan Pengertian yang Abstrak Kepada Pengertian yang Konkrit dan Jelas

Materi pembelajaran sering kali adalah sesuatu yang bersifat abstrak. Hal yang abstrak ini tidak mudah dipahami terutama untuk anak usia dini. Oleh karena itu, media mampu menjadikan sesuatu yang bersifat abstrak dapat dipahami secara konkrit dan jelas. Misalnya ketika mengajarkan makna kasih sayang, Tuhan, Malaikat, dan lain-lain.

4. Mengatasi Keterbatasan Ruang, Waktu dan Daya Indera Manusia

Manusia memiliki keterbatasan indera untuk bisa memahami tentang seluk beluk lingkungan kehidupannya jika hanya mengandalkan daya inderanya. Oleh karena itu, manusia membutuhkan bantuan berbagai alat yaitu denagn menggunakan berbagai media. Hal ini sesuai dengan karakteristik media sebagaimana yang dikemukan oleh Arsyad (2016) yaitu :

a. Ciri Fiksatif (Fixative Property) 
Ciri fiksatif ini dimana media dapat menangkap, menyimpan, dan merekomendasikan suatu objek atau peristiwa yang telah terjadi di masa lampau. Misalnya foto/kamera, film, video, film bingkai, dan lain-lain.

b. Ciri Manipulatif (Manipulative Property)

Pada ciri ini media dapat mengubah objek, waktu, dan peristiwa menjadi 3 hal: close up (objek yang terlalu kecil terlihat lebih besar;luv, mikroskop, dan lain-lain), time lapsel high-speed photography (gerak yang terlalu lambat dapat lebih cepat:kamera), dan slow motion (gerak yang terlalu cepat dapat diperlambat:kamera), objek yang terlalu besar dapat diperkecil dengan miniatur, gambar, maket, dan lain-lain.

c. Ciri Distributif (Distributuve Property)

Media dapat menyajikan suatu peristiwa dalam radius yang luas seperti gunung berapi, iklim, dan lain-lain sehingga divisualisasikan dalam bentuk film, dan lain-lain.

5. Penggunaan Media Pembelajaran yang Tepat akan Dapat Mengatasi Sikap Pasif Anak Didik

Dengan penggunaan media, anak diberi kesempatan untuk bereksperimen, dan bereksplorasi secara luas terhadap media tersebut. Sebagaimana Zaman, dkk (2005), menjelaskan bahwa penggunaan media akan berguna untuk:

1).Menimbulkan kegairahan belajar

2).Memungkinkan interaksi yang lebih langsung antara anak didik dengan lingkungan dan kenyataan.

3).Memungkinkan anak didik belajar sendiri-sendiri menurut kemampuan dan minatnya.

6. Mengatasi Sifat Unik pada Setiap Anak Didik yang diakibatkan oleh Lingkungan yang Berbeda 


\section{Media Pembelajaran Anak Usia Dini}

Setiap anak didik berasal dari lingkungan keluarga yang memiliki budaya, agama, tingkat pendidikan, dan sosial ekonomi yang berbeda-beda. Oleh karena itu, setiap anak didik memiliki keunikan tersendiri dan berpengaruh terhadap proses belajar-mengajar. Dalam hal ini, guru dituntut untuk menggunakan media yang sesuai dengan para anak didiknya. Misalnya guru menggunakan variasi media untuk mengatasi perbedaan gaya belajar para anak didiknya, sehingga media tersebut akan:

1). Memberikan perangsang yang sama;

2).Mempersamakan pengalaman;

3).Menimbulkan persepsi yang sama.

7. Media Mampu Memberikan Variasi dalam Proses Belajar Mengajar

Dengan menggunakan media yang bervariasi, maka suasana pembelajaranpun akan bervariasi dan menarik bagi anak. Hal ini dikarenakan setiap media memiliki karakteristik yang memungkinkan kegiatan pembelajaran dapat dilakukan dalam berbagai cara dan metode.

8. Memberi Kesempatan pada Anak Didik untuk Mereview Pelajaran yang Diberikan

Dalam proses belajar-mengajar mungkin saja ada beberapa informasi yang terlewat oleh anak. Dengan melihat kembali media yang digunakan oleh guru dalam menerangkan, anak dapat merevisi kembali informasi pelajaran yang pernah diterimanya tersebut.

9. Memperlancar Pelaksanaan Kegiatan Belajar Mengajar dan Mempermudah Tugas Para Guru

Fungsi utama media pembelajaran adalah sebagai alat bantu mengajar. Menurut Hamalik (dalam Arsyad 2016) pemakaian media dalam proses pembelajaran dapat meningkatkan keinginan dan minat yang baru, mem- 
bangkitkan motivasi dan rangsangan kegiatan belajar, dan juga berpengaruh pada psikologis murid. Artinya dengan penggunaan media pembelajaran akan dapat menanbah gairah anak dalam belajar. Anak akan terpancing untuk mengikuti pembelajaran dengan tekun dan juga akan dapat menimbulkan rasa ingin tau yang tinggi.

Menurut Levie \& Lentz (Basuki Wibawa, 1993) mengemukakan fungsi media pembelajaran sebagai berikut:

1. Fungsi atensi yaitu menarik dan mengarahkan perhatian murid pada isi pelajaran dibantu dengan media gambar sehingga memiliki kemungkinan mengingat isi pelajaran lebih besar.

2. Fungsi afektif yaitu muncul ketika belajar dengan teks yang bergambar, sehingga dapat menggugah emosi dan sikap murid.

3. Fungsi kognitif yaitu mengungkapkan gambar memperlancar pencapaian tujuan memahami dan mengingat informasi yang terkandung.

4. Fungsi kompensatoris yaitu berfungsi mengakomodasikan murid yang lemah dan lambat menerima dan memahami isi pelajaran yang disajikan dengan teks.

Selanjutnya Sudjana dan Rivai (2017), mengemukan manfaat media pembelajaran untuk meningkatkan proses belajar bagi siswa yaitu:

1. Pembelajaran akan lebih menarik perhatiaan siswa sehingga dapat menumbuhkan motivasi belajar.

2. Bahan pengajaran akan lebih jelas maknanya sehingga dapat lebih dipahami oleh para siswa, dan memungkinkan siswa menguasai tujuan pengajaran lebih baik.

3. Metode mengajar akan lebih bervariasi, tidak semata-mata komunikasi verbal melalui penuturan kata-kata oleh guru, 
sehingga siswa tidak bosan dan guru tidak kehabisan tenaga, apabila guru mengajar untuk setiap jam pelajaran.

4. Siswa lebih banyak melakukan kegitan belajar, sebab tidak hanya mendengarkan uraian guru, tetapi juga aktivitas lain seperti mengamati, melakukan, mendonstrasikan, dan lain-lain.

Menurut Kemp \& Dayton (Arsyad, 2016) mengemukan dampak positif dari penggunaan media pembelajaran yaitu:

1. Penyampaian pembelajaran menjadi lebih baku. Adanya penafsiran yang berbeda-beda dari cara guru menyampaikan pembelajaran, namun dengan adanya media pembelajaran maka akan dapat teratasi.

2. Pembelajaran bisa lebih menarik.

Adanya pemakaian media dalam pembelajaran akan dapat menimbulkan ketertarikan siswa terhadap pembelajaran. Maka penyampaian pesan dalam pembelajaran akan lebih jelas sehingga anak akan termotifasi dan membaut anak ingin tahu terhadap pembelajaran yang disampaikan.

3. Pembelajaran lebih interaktif dengan diterapkannya teori belajar dan prinsip-prinsip psikologis yang diterima dalam hal partisipasi siswa, umpan balik, penguatan.

4. Lama waktu pembelajaran yang diperlukan dapat dipersingkat dengan adanya media pembelajaran.

5. Kualitas hasil belajar dapat ditingkatkan bilamana integrasi kata dan gambar sebagi media pembelajaran dapat mengkomunikasikan elemen-elemen pengetahuan dengan cara yang terorganisasi dengan baik, sfesifik, dan jelas.

6. Pembelajaran dapat diberikan kapan dan dimana diinginkan atau diperlukan terutama jika media pembelajaran dirancang untuk penggunaan secara individu. 
7. Sikap positif siswa terhadap apa yang mereka pelajari dan terhadap proses belajar dapat ditingkatkan.

8. Peran guru dapat berubah kearah yang lebih positif, guru tidak mesti lagi menyampaikan materi pembelajaran dengan berulang-ulang tapi guru dapat meningkatkatkan pada kegiatan yang lain dalam proses belajar mengajar seperti penasihat siswa.

Untuk memahami peranan media dalam proses mendapatkan pengalaman belajar bagi murid, Edgar Dale melukiskannya dalam sebuah kerucut yang kemudian dinamakan Kerucut Pengalaman Edgar Dale (Edgar Dale cone of experience). Kerucut pengalaman ini dianut secara luas untuk menentukan alat bantu atau media apa yang sesuai agar murid memperoleh pengalaman belajar secara mudah. Kerucut pengalaman yang dikemukakan oleh Edgar Dale itu memberikan gambaran bahwa pengalaman belajar yang diperoleh murid dapat melalui proses perbuatan atau mengalami sendiri apa yang dipelajari, proses mengamati, dan mendengarkan melalui media tertentu dan proses mendengarkan melalui bahasa.

Semakin konkrit murid mempelajari bahan pengajaran, contohnya melalui pengalaman langsung, maka semakin banyaklah pengalaman yang diperolehnya. Sebaliknya semakin abstrak murid memperoleh pengalaman, contohnya hanya mengandalkan bahasa verbal, maka semakin sedikit pengalaman yang akan diperoleh murid. (Sanjaya, 2008)

Berdasarkan beberapa fungsi dan manfaat media pembelajaran yang telah dikemukakan oleh para ahli, tampaklah bahwa penggunaan media pembelajaran dalam proses belajar mengajar memiliki pengaruh dan dampak yang besar terhadap minat dan motivasi siswa. Selain itu dengan penggunaan media 
pembelajaran juga akan memberi keringanan dan kemudahan bagi guru dalam menyajikan dan membelajarkan siswa. Sehingga pembelajaran akan lebih berpusat pada siswa bukan pada guru. Karena siswa akan dapat melakukan kegiatankegiatan pengembangan dalam pembelajaran seperti mengamati dan mengkomunikasikan. Dengan begitu guru akan dapat meningkatkan perannya sebagai pengajar dan pendidik.

Hal ini terjadi karena adanya usaha untuk menjadikan pembelajaran dari yang abstrak ke kongkrit melalui pengasahan alat-alat indra. Karena dengan adanya media pembelajaran siswa akan dapat melihat, mendengar, bahkan meraba, sesuai dengan materi yang disampaikan. Pada anak usia dini yang meliliki langgam belajar yang berbeda dengan anak SD atau SMP. Sebagaimana hasil penelitian Lynn O'Brien dari SDS (1997), mengatakan bahwa anak usia dini memiliki tiga macam langgam belajar yaitu: haptik/ kinestetik, Visual dan auditorial. Anak yang memiliki langgam haptik atau kinestetik, belajar lebih optimal dengan cara menyentuh, membongkar-pasang, dan melakukan (learning by doing). Anak berlanggam belajar visual akan lebih cepat mengerti jika belajar melalui gambar, skema, atau membaca. Sedangkan anak auditorial lebih suka belajar dengan mendenggarkan suara atau musik (Slamet 2005). Untuk itu penggunaan media yang tepat tentu sangat dapat membantu anak dalam memahami pembelajaran yang diberikan oleh guru.

\section{Pengelompokkan Media Pembelajaran}

Media pembelajaran sebagai sarana untuk mengkongkritkan materi pembelajaran dan meransang siswa untuk belajar merupakan komponen instruksional yang meliputi pesan, teknik latar, dan peralatan (Arsyad 2016) Dengan masuknya berbagai pengaruh ke dalam dunia pendidikan ini, 
laju perkembangan teknologi yang semakin maju, media pembelajaran terampil dalam berbagai jenis sesuai kemampuan masing-masing. Menurut Seels dan Richey (dalam Arsyad 2016), mengatakan berdasarkan teknologi media pembelajaran dapat dikelompokan atas empat yaitu:

1. Media hasil teknologi cetak, cara untuk menyampaikan materi seperti: buku dan materi visual statis.

2. Media hasil teknologi audio-visual, yaitu cara menghasilakan atau menyampaikan materi dengan menggunakana mesin-mesin mekanis dan elektronik untuk menyajikan pesan-pesan audio dan visual.

3. Media hasil teknologi yang berdasrkan komputer, yaitu cara menghasilkan atau menyampaikan materi dengan menggunakan sumber-sumber yang berbasis mikroprosesor. Pada kelompok ini media pembelajaran disimpan dalam bentuk digital, bukan dalam bentuk cetakan atau visual.

4. Media hasil gabungan teknologi cetak dan komputer. Yaitu: cara untuk menghasilkan dan menyampaikan materi yang mengabungkan pemakaian beberapa bentuk media yang dikendalikan oleh komputer.

Menurut Sudjana dan Rivai (2017) adapun media pengajaran yang digunakan dalam proses pengajaran adalah:

1. Media grafis yang disebut juga dengan media dua dimensi, seperti gambar, poster, kartun, dan lain-lain.

2. Media tiga dimensi yaitu dalam bentuk model seperti model padat (solid model), model penampang, model susun, model kerja, mock up, diorama, dan lain-lain.

3. Media proyeksi seperti slide, strips, film, pengginaan OHP, dan lain-lain.

4. Penggunaan lingkungan sebagai media pengajaran. 
Gagne (dalam Jalinus dan Ambiar 2016) menjelaskan tentang pengelompokan media pembelajaran berdasarkan tingkatan hierarki belajar yaitu 1) media yang dapat didemonstrasikan, 2) komunikasi liasn, 3) media cetak, 4) gambar diam, 5) gambar gerak, 6) film bersuara, 7) dan mesin belajar. Dari pengelompokan media pembelajarn yang telah dikemukan dari para ahli sebelumnya, Zaman, dkk (2005) mengelompokan media pembelajaran menjadi tiga kelompok dapat dikembangkan untuk anak usia dini. Ketiga kelompok tersebut diklasifikannya dalam bentuk gambar yaitu:

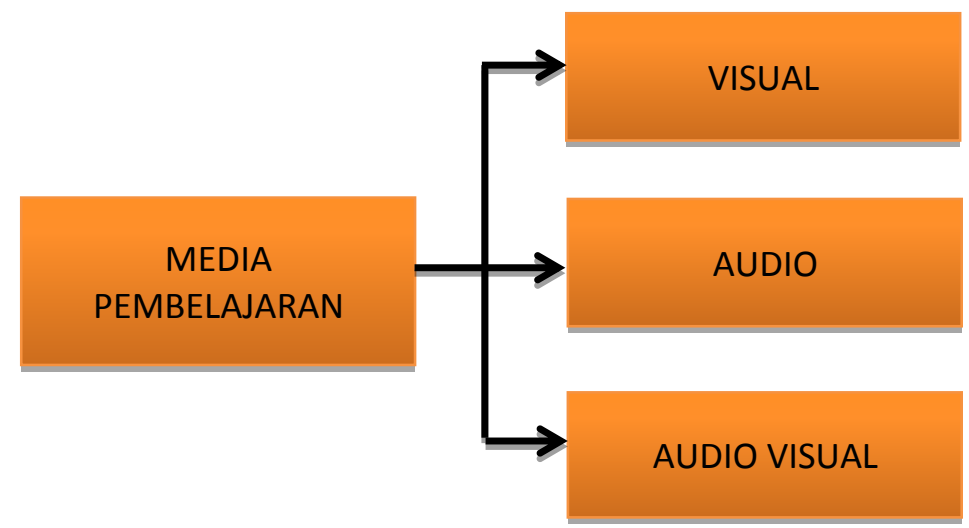

Gambar1 Klasifikasi Media Pembelajaran

\section{Media Visual}

Zaman dkk, (2005) media visual adalah media yang menyampaikan pesan melalui penglihatan pemirsa atau media yang hanya dapat dilihat. Jenis media ini yang paling sering digunakan dalam pembelajaran. Untuk penyampaian pembelajaran pada anak usia dini media visual ini sangat tepat karena sesuai dengan sifat dan cara belajar anak yang menhendaki pembelajaran secara konkret. Zaman dkk, (2005) mengatakan bahwa media visual ini terdiri atas media yang dapat diproyeksikan 
(projected visual) dan media yang tidak dapat diproyeksikan (non-projected visual). Jenis media yang dapat diproyeksikan (projected visual) untuk menyampaikan pesan pendidikan untuk TK/ anak usia dini antaranya: OHP (overhead projection) dan slaid suara (soundslide).

2. Media Audio

Zaman dkk, (2005) mengatakan media audio adalah media yang mengandung pesan dalam bentuk auditif (hanya dapat didengar) yang dapat merangsang pikiran, perasaan, perhatian, dan kemauan anak untuk mempelajari isi tema. Contoh media audio yaitu program kaset suara dan program radio. Menurut Sudjanah dan Rivai (2016) mengatakan media audio untuk pengajaran dimaksudkan sebagai bahan yang mengandung pesan dalam bentuk auditif (pita suara atau piringan suara yang dapat meransang pikiran, perasaan, perhatian dan kemauan siswa, sehingga terjadi proses belajar mengajar.

Jadi dapat dikatakan bahwa media audio lebih banyak digunakan untuk meransang siswa dalam belajar yang sifatnya didengarkan. Seperti halnya pemutaran lagu-lagu yang pada saat bermain diluar kelas. Anak akan dapat mendengarkan musik atau lagu-lagu yang sifatnya menuntun anak mencitai keindahan alam atau lagu-lagu yang dapat mengajak anak untuk berbuat baik terhadap orang tua dan sesama, dan lain sebagainya

3. Media Audio Visual

Menurut Zaman dkk (2005) Media audio visual adalah kombinasi antara media audio dan media visual atau biasa disebut media pandang dengar. Dia mengatakan penggunakan media audio visual ini dapat penyajian isi 


\section{Media Pembelajaran Anak Usia Dini}

tema kepada anak akan semakin lengkap dan optimal. Selain itu media ini dalam batas-batas tertentu dapat juga menggantikan peran dan tugas guru.

Penggunaan media audio visual ini untuk penyampaian pembelajaran pada anak usia dini sangat tepat sekali karena media ini akan dapat minat anak untuk belajar, apalagi kalau isi pembelajaran yang akan disampaikan dikemas dalam bentuk cerita yang menarik. Contoh dari media audio visual ini di antaranya program televisi/video pendidikan/instruksional, program slide suara.

Berdasarkan beberapa pengelompokkan media pembelajaran yang telah dikemukan sebelumnya, maka dapat disimpulkan bahwa media pembelajaran bermacam-macam, yaitu media berupa gambar, media berupa gerak, media berupa tulisan, dan media berupa suara. Media yang banyak dikenal orang adalah media audio, visual, dan audio visual. Karena media bermacam-macam, tugas guru adalah memilih media yang tepat untuk anak didiknya yang harus sesuai dengan tujuan dan materi pembelajaran.

Menentukan dan memilih media yang terbaik dalam proses belajar dan mengajar merupakan sesuatu yang penting. Namun, hal ini kadang membingungkan bagi para pendidik, tetapi di sisi lain juga merupakan momen untuk penilaian kreatifitas mereka. Menurut Mc.M.Connel (Indriani, 2011) mengatakan dengan tegas agar menggunakan media yang memiliki kesesuaian dengan kebutuhan belajar. Dengan demikian, secara sederhana media apa pun dapat digunakan dalam aktifitas belajar mengajar asalkan sesuai dengan tujuan pembelajaran dan pengajaran itu sendiri. Menurut Sudjana (2016) mengemukakan beberapa kriteria dalam memilih media pembelajaran, sebagai berikut:

1) Ketepatan dengan tujuan pembelajaran; 
2) Dukungan terhadap isi bahan pembelajaran, adanya media pembelajaran akan lebih mudah dipahami murid;

3) Media yang digunakan mudah diperoleh, murah, sederhana, dan praktis penggunaannya;

4) Keterampilan guru dalam menggunakan media dalam proses pembelajaran;

5) Bermanfaat bagi murid selama pembelajaran berlangsung;

6) Sesuai dengan taraf berpikir murid.

Berpijak pada kreteria media yang dikemukan Sudjana ini tentu seorang guru dituntut untuk dapat menentukan dan memilih media yang sesuai untuk pembelajaran anak usia dini. Karena ketepatan pemilihan media akan dapat mempenggaruhi minat anak untuk belajar. Banyaknya jenis dan kelompok media yang ada belum tentu semua dapat cocok untuk penyampaian pembelajaran untuk anak usia dini, untuk itu guru sebaiknya memilki pengetahuan tentang jenis dan karakter media pembelajaran sebagaimana yang dikemukakan oleh Zaman dkk (2005) bahwa perencanaan dan pemilihan media pembelajaran merupakan bagian integral dari penggunaan media pembelajaran di TK. Untuk itu dalam memilih dan merencanakan penggunaan media pembelajaran perlu dipertimbangkan:

1) karakteristik dari media

2) kehandalannya

3) cara pembuatannya

4) dan cara penggunaannya. 
18 Media Pembelajaran Anak Usia Dini 


\section{BAB II \\ SUMBER BELAJAR UNTUK ANAK USIA DINI}

\section{A. Pengertian Sumber Belajar}

Sumber belajar adalah segala sesuatu yang terdapat dilingkungan disekitar anak yang dapat dipergunakan atau dimanfaatkan untuk membantu pemahaman anak dalam proses belajar mengajar. Menurut Januszewski dan Molendsa (dalam Arsyad, 2016) mengatakan Istilah sumber belajar dipahami sebagai perangkat, bahan (materi), peralatan, pengaturan, dan orang dimana pembelajar dapat berinteraksi dengannya yang bertujuan untuk memfasilitasi belajar dan memperbaiki kinerja.

Menurut Asosiasi Teknologi komunikasi pendidikan (AECT) (dalam Jalinus dan Ambiar 2016)), sumber belajar adalah semua sumber (baik berupa data, orang atau benda, yang dipergunakan untuk memberi fasilitas atau kemudahan belajar bagi siswa. Sudjana ( dalam Zaman dkk, 2005) mengatakan bahwa sumber belajar adalah segala daya yang dapat dimanfaatkan guna memberi kemudahan kepada seseorang dalam belajar. Sudono (2000) mengartikan sumber belajar adalah bahan termasuk juga alat permainan untuk memberikan informasi maupun berbagai keterampilan kepada murid maupun guru antara lain buku referensi, buku cerita, gambargambar, nara sumber, benda atau hasil-hasil budaya. Trianto (2011), mengatakan bahwa sumber belajar mencakup semua sumber yang mungkin dapat digunakan oleh anak agar terjadi prilaku belajar.

Menurut Jalinus dan Ambiar, (2016) sumber belajar dapat dibedakan menjadi dua yaitu Pertama sumber belajar yang dirancang (learning resources by desingn) yaitu sumber belajar yang memang sengaja dirancang untuk tujuan pembelajaran. 
Contohnya buku pelajaran, modul, program audio, transparansi (OHT). Kedua sumber belajar yang sudah tersedia dan tinggal dimanfaatkan (learning by utilization), yaitu sumber belajar yang tidak secara khusus dirancang untuk keperluan pembelajaran, namun dapat ditemukan, dipilih dan di-manfaatkan untuk keperluan pembalajaran.

Bertolak dari beberapa pendapat ahli tentang sumber belajar maka dapat diambil batasan bahwa sumber belajar adalah segala macam sumber, bahan, dan daya, yang dirancang khusus maupun dimanfaatkan secara lansung untuk memberikan informasi dan keterampilan bagi guru maupun anak dalam porses belajar mengajar untuk mencapai tujuan pembelajaran. Dengan adanya sumber belajar tentu akan dapat memberikan kemudahan dalam menerima dan memahami pembelajaran bagi anak. Dan sebaliknya bagi guru tentu akan dapat memberikan kemudahan dalam penyampaian materi pembelajaran.

Pada pembelajaran anak usia dini semua sumber dan bahan yang ada disekitar lingkungan anak dapat dijadikan sebagai sumber belajar. Misalnya taman bunga yang ada ada dihalaman sekolah, atau kebun binatang, supermaket, kolam ikan, dan lain sebagainya. Selain itu hal-hal yang dekat secara emosional dengan anak seperti hobi, hal-hal yang disukai anak, film, dan lainnya, juga dapat dijadikan sumber belajar yang dikembangkan melalui tema-tema pembelajaran. Pengembangan sumber belajar yang bervariasi tentu tidak lepas dari kreativitas guru dalam mengembangkan dan mengemas pembelajaran tersebut.

\section{B. Fungsi dan Manfaat Sumber Belajar}

Fungsi dan manfaat sumber belajar dalam pembelajaran anak usia dini tentu didasari atas hubungannya dengan 
kebermanfaatan sumber belajar tersebut dalam mengoptimalkan belajar anak. Anak akan belajar secara optimal apa bila anak tertarik dengan apa yang dipelajarinya. Salah satu cara untuk mengoptimalkan adalah dengan menberikan sumber belajar yang menarik minat belajar anak. Untuk itu sumber belajar memeliki beberapa fungsi, sebagai mana yang dikemukan oleh Jalinus dan Ambiar, (2016)yaitu:

1. Meningkatkan produktivitas pembelajaran.

2. Memberikan pembelajaran yang sifatnya lebih individual.

3. Memberikan dasar yang lebih ilmiah terhadap pembelajaran.

4. Memungkinkan belajar secara seketika.

5. Memungkinkan penyajian pembelajaran yang lebih luas, dengan menyajikan informasi yang mampu menebus batas geografi.

Menurut Zaman dkk, (2005) menjelaskan bahwa sumber belajar memiliki beberapa fungsi atau manfaatYaitu:

1. Dapat memberikan pengalaman belajar yang lebih konkret dan langsung. Anak usia dini yang berada pada fase berfikir konkret, artinya bahwa anak usia dini belum mampu berfikir di luar batas kemampuan panca indranya atau secara abstrak. Maka dengan pemberian pengalaman belajar nyata/konkret tentu akan mengoptimalkan belajar anak, dan juga akan dapat meningkatkan kebermaknaan dalam proses belajarnya.

2. Upaya memperluas wawasan anak melalui sumber belajar. Misalnya guru mengajak anak mengamati ikan di dalam kolam atau aquarium, anak akan mendapatkan pengalaman tentang berbagai warna ikan, besar kecilnya ikan yang ada dalam kolam atau aquarium, bagaimana ikan bergerak di dalam air, 
dan sebagainya.

3. Dapat memberikan informasi yang akurat dan terbaru. Misalnya informasi yang didapat anak dari buku bacaan, majalah anak atau nara sumber. Ini sangat menguntungkan bagi anak sehingga ia akan dapat informasi dan pengetahuan baru. Pengetahuan baru bagi anak akan meningkatkan minat dan akhirnya akan terlatih karena adanya pembiasaan.

4. Motivasi anak untuk belajar selalu menjadi fokus perhatian guru dalam pengelolaan pembelajaran anak usia dini. Faktor motivasi sering menjadi masalah yang menyebabkan tidak terciptanya iklim belajar yang kondusif dan menyenangkan. Dengan memanfaatkan sumber belajar menjadi alternatif bagi guru untuk masalah tersebut.

5. Mengembangkan kemampuan berfikir anak secara krtitis dan positif. Dengan diberikannya berbagai alternatif sumber belajar kepada anak kemampuan berfikir kritis anak akan meningkat. Contohnya pada saat anak secara lansung proses belajar, misalnya di kebun binatang, anak akan secara otomatis berkembang pemikiran kritisnya. Hal tersebut ditunjukan oleh anak dengan banyak mengemukan pertanyaan terhadap berbagai fakta, peristiwa, kejadian yang ditemukannya di tempat teresebut, bahkan hal-hal yang tidak terfikirkan oleh guru sekalipun akan ditanyakan. Kondisi tersebut menunjukan bahwa anak berkembang kemampuan berfikir kritis dan berfikir positifnya.

\section{Klasifikasi Sumber Belajar}

Masalah sumber belajar adalah hal yang tidak bisa dipisahkan dengan pembelajaran. Bagaimanapun sumber 
belajar merupakan bagian yang terpenting terutama untuk anak usia dini. Pada pembelajararan anak usia dini tanpa adanya media atau sumber belajar maka sulit untuk mebelajarkan anak. Namun bagaimanpun sumber belajar untuk anak usia dini sangat banyak pula tersedia disekitarnya. Guru akan dapat memanfaatkan apa saja yang ada disekitar dan lingkungan anak. Tapi sumber belajar yang banyak tersebut dapat diklasifikasi atau dikelompokan. Sesuai dengan pengertian sumber belajar yang dikemukakan oleh AECT (Association for educational communication and tecnology) dan teknologi pendidikan membagi sumber belajar (dalam Zaman 2005), yang dikelompokan dalam 6 jenis yaitu pesan, orang, bahan, peralatan, teknik, dan lingkungan. Peranan sumber belajar dalam pembelajaran adalah mentransmisikan ransangan atau informasi kepada anak. Menurut Trianto (2011),Transmisi disini berkaitan dengan pertanyaan (1) apa informasi yang akan ditransmisikan? (2) siapa yang melakukan Transmisi? (3) Apa yang menyimpan informasi? (4) Bagaimana informasi itu ditransmisikan?, (5) Dimana informasi itu ditransmisikan.

Berdasarkan pertanyaan ini, dan mengidentifikasi jawabannya, maka dapat dioraganisasikan sumber belajar sebagai berikut:

Apa informasi yang akan ditransmisikan? ------ Pesan

Siapa yang melakukan transmisi? ------ Orang

Yang menyimpan informasi ----- Bahan/alat

Bagaimana informasi itu di transmisikan? ------ Teknik

Di Mana ditransmisikan ------ Latar

Untuk lebih rincinya klasifikasi sumber balajar terlihat dari skema yang dikemukan oleh AECT (dalam Zaman dkk, (2005) sebagai berikut: 


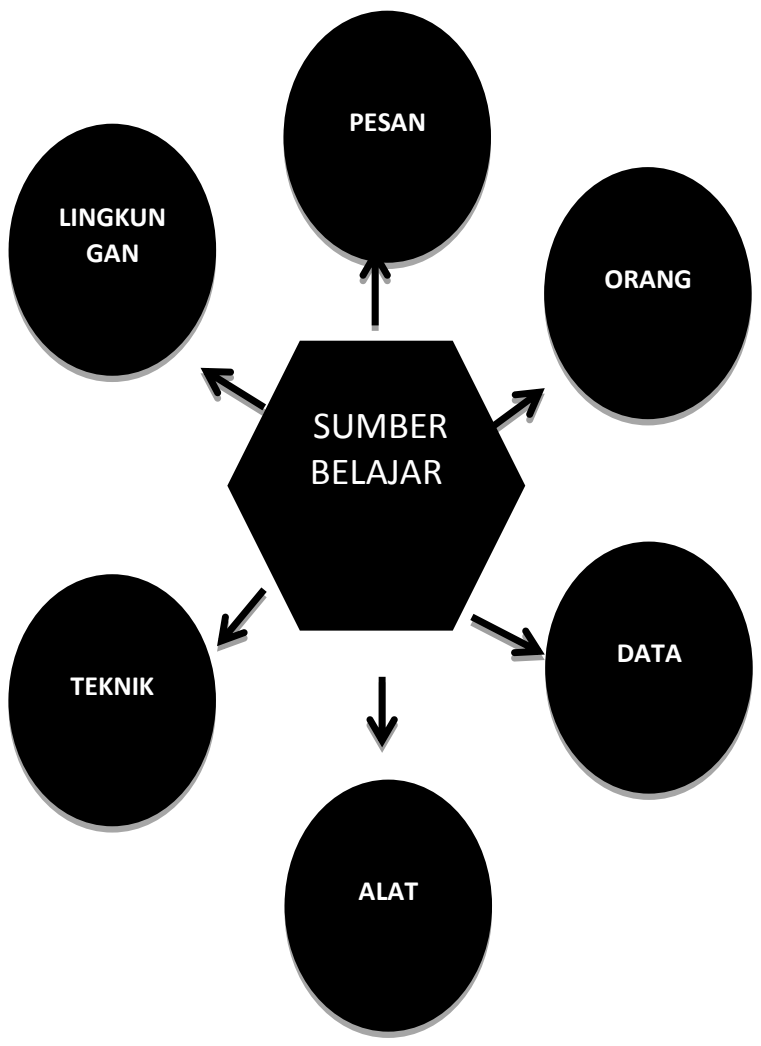

Gambar 3 Bagan Sumber Belajar menurut AECT

\section{Pesan (messege)}

Menurut Jalinus dan Ambiyar, (2016) mengatakan pesan adalah: sumber belajar yang meliputi pesan formal yaitu yang dikeluarkan oleh lembaga resmi seperti pemerintah atau pesan yang disampaikan guru dalam situasi pembelajaran.

Pesan sebagai sumber belajar adalah segala informasi yang harus disalurkan oleh komponen yang lain yang berbentuk ide, fakta, pengertian dan data. Contonya 
adalah bahan-bahan ajar yang terdapat dalam program/ kurikulum PAUD. Bahan-bahan ajar yang terdapat dalam program/kurikulum tersebut harus disampaikan oleh komponen lain yaitu guru. Guru menyampaikan segala bahan ajar sehingga anak mendapat pengetahuan dan informasi tertentu.

\section{Orang}

Orang sebagai sumber belajar adalah mendatangkan atau menjadikan seseorang yang memiliki profesi dan keahlian yang berhubungan dengan materi pembelajaran. Contohnya dokter, polisi, koki, dan lain sebagainya.

Menurut Jalinus dan Ambiyar, (2016), orang sebagai sumber belajar dapat dibagi atas dua ketegori yaitu: pertama, kelompok orang yang didesain khusus sebagai sumber belajar utama yang didik secara profesional untuk mengajar seperti: guru, konselor, intruktur, dan widyaswara. Termasuk kepala sekolah, laboran, teknisi sumber belajar, pustakawan dan lain-lain, kedua, orang yang memiliki profesi selain tenaga yang berada dilingkungan pendidikan dan profesinya tidak terbatas, misalnya politisi, polisi, tenaga kesehatan, pertanian, arsitek, psikolog, dan pengusaha. Seperti terlihat pada gambar, 4 berikut ini yaitu seorang koki dan petani ikan sedang menjelaskan tentang pembuatan roti dan berternak ikan. 

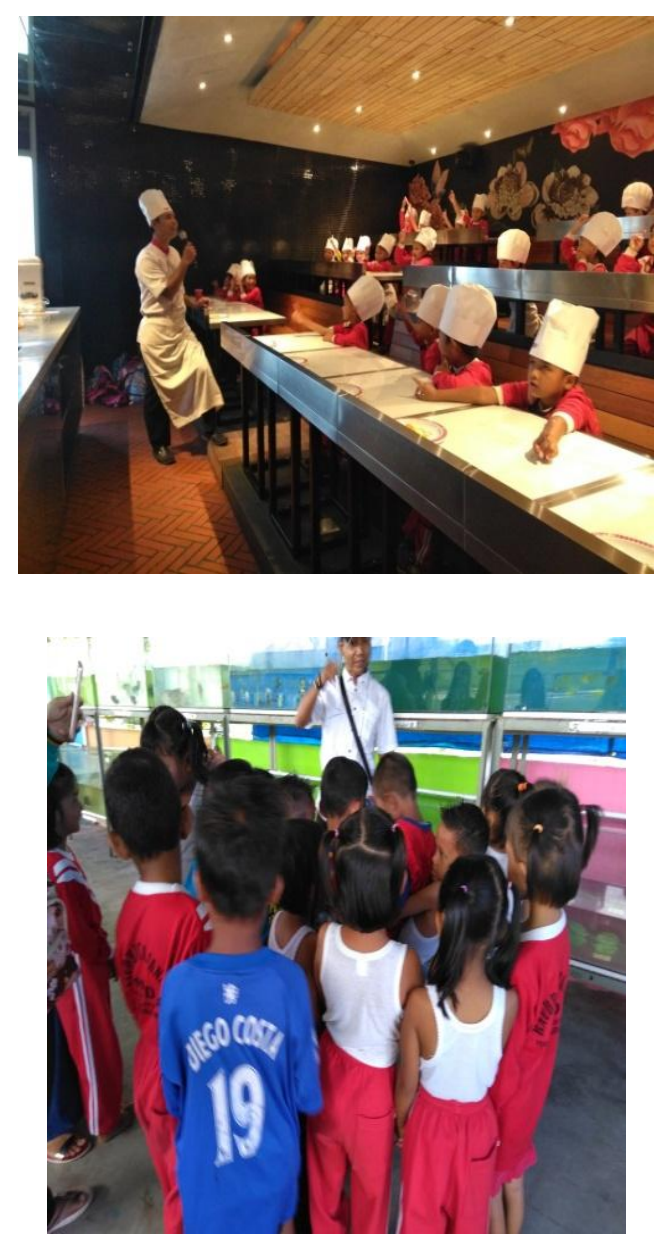

Gambar 4 Orang sebagai sumber belajar

\section{Bahan}

Yang dimaksud dengan bahan sebagai sumber belajar adalah sesuatu yang sering disebut media/software yang mengandung pesan untuk disajikan melalui penggunaan alat atau dirinya sendiri. Seperti buku-buku, program video, program slide projector, film dan lain sebagainya. Menurut Trianto, (2011) yang dimaksud bahan sebagai 
sumber belajar adalah suatu format yang digunakan untuk menyimpan pesan pembelajaran.

\section{Alat}

Alat yang dimaksud disini adalah sesuatu benda atau alat yang disebut media/ hardware yang digunakan untuk menyampaikan pesan yang tersimpan dalam bahan tersebut. Seperti Tape Recorder, yang digunakan untuk memutar lagu-lagu yang disukai anak-anak, slide projector, OHP, Film, dan sebagainya.

\section{Teknik}

Menurut Zaman dkk, (2005) Teknik dalam sumber belajar adalah prosedur yang disiapkan dalam mempergunakan bahan pelajaran, peralatan, situasi, dan orang menyampaikan pesan. Atau dengan kata lain teknik adalah cara yang digunakan guru dalam meberikan pembelajaran guna untuk tercapainya tujuan pembelajaran. Contoh guru menggunakan metode demonstrasi untuk memberi contoh cara membuat gambar dengan jari tangan.

\section{Lingkungan}

Lingkungan disebut juga latar. Yang dimaksudnya lingkungan atau latar adalah situasi disekitar dimana pesan disampaikan atau disalurkan. Yang dimaksud sumber belajar lingkungan atau juga yang berada di dalam sekolah maupun diruar sekolah, baik yang sengaja dirancang maupun tidak secara khusus disiapkan untuk pembelajaran. Termasuk didalamnya adalah pengaturan ruang, pencahayaan, ruang kelas, perpustakaan, alat permainan, area, sentra-sentra, atau sudut-sudut pengem- 
bangan dan sebagainya. Selain sumber-sumber tersebut untuk anak usia dini alat permainan edukatif (APE) juga dapat dijadikan sebagai sumber belajar. Sebagaimana Zaman dkk, (2005) mengatakan bahwa alat permainan edukatif memiliki peran penting dalam pembelajaran anak TK /AUD. Inti kegiatan belajar anak adalah bermain. 


\section{III \\ ALAT PERMAINAN EDUKATIF (APE) UNTUK ANAK USIA DINI}

\section{A. Pengertian Alat Permainan Edukatif (APE)}

Selain media dan sumber belajar pada pembelajaran anak usia dini juga diperlukan alat permaianan (APE). Walaupun alat permainan juga merupakan bagian dari sumber belajar. Sesuai dengan prinsip belajar anak usia dini yaitu bermain seraya belajar. Karena bermainnya anak usia dini sama dengan tahap belajar. Dalam bermain anak akan mendapatkan pengalamanpengalaman baru yang dapat mengasah pertumbuhan dan perkembangan anak. Untuk itu perlu adanya alat-alat permainan yang dapat dipergunakan untuk kegiatan belajar tersebut.

Alat permainan edukatif (APE) adalah bermacam-macam peralatan atau sesuatu benda yang dapat dipergunakan untuk bermain. Yang mana peralatan atau benda tersebut dapat menstimulasi dan mengembangkan seluruh kemampuan anak. APE merupakan alat bantu bermain sambil belajar yang meliputi alat-alat untuk bermain bebas dan kegiatan-kegiatan di bawah pimpinan guru. Menurut Meyke (dalam Zaman dkk, 2005), mengatakan bahwa APE adalah alat permainan yang sengaja dirancang secara khusus untuk kepentingan pendidikan. Selanjutnya Depdiknas Dirjen PAUD (2007) menjelaskan bahwa alat permainan edukatif (APE) adalah segala sesuatu yang dapat digunakan sebagai sarana atau peralatan untuk bermain yang mengandung nilai edukatif (pendidikan), dan dapat mengembangkan seluruh kemampuan anak.

Berpijak dari beberapa pendapat ahli yang sudah dijelaskan maka dapat disimpulkan bahwa alat permainan 
edukatif (APE) adalah alat permainan yang sengaja dirancang untuk pendidikan dan pengembangan anak usia dini. Alat permainan yang dirancang tersebut hendaknya dapat mengembangkan beberapa aspek perkembangan anak. Menurut Harvard (dalam Pamilu,2007), ada 8 aspek kecerdasan yang dimiliki oleh setiap anak. Aspek kecerdasan ini disebut juga dengan kemampuan atau potensi yang terdapat dalam diri anak ketika anak sedang belajar tentang dunianya. Kemampuan tersebut adalah:

1. Kemampuan Verbal (linguistik intelligence)

Yaitu kemampuan dalam menggunakan kata-kata secara efektif. Kemampuan ini berkaitan juga dengan kemampuan berbicara. Untuk pengembangannya kemampuan ini dapat distimulasi melalui membaca, menulis, berdiskusi, bercerita. Pada anak usia dini dilakukan dengan bermain kata-kata.

2. Kemampuan Logika-Matematik (togico- mathematical intelligence)

Yaitu kemampuan berfikir logis, kemampuan mengenal pola dan bekerja dengan konsep-konsep yang abstrak. Pada anak usia dini kemampuan ini dapat distimulasi dengan menghitung, membedakan bentuk, analisa data, bermain dengan benda-benda.

3. Kemampuan visual- spasial (visual-spatial intellegence)

Yaitu kemampuan melakukan persepsi secara tepat dan kemampuan menginggat pola-pola visual. Kemampuan ini dapat distimulasi melalui kertas warna-warni, balokbalok, puzzle, menggambar, melukis, menonton film, pada kemampuan ini anak bermain dengan imajinasi.

4. Kemampuan Musikal (musical-rhytmic intelligence)

Yaitu kemampuan untuk membedakan berbagai macam suara dan menciptakan musik. Ini dapat distimulasi 
melalui bunyi-bunyian, nada, memainkan instrumen musik, tepuk tangan, dan sebagainya.

5. Kemampuan Kinestetik (bodily/kinesthetic intelligence) Yaitu kemampuan untuk melakukan gerakan tubuh sebagaimana yang dimiliki oleh penari atau atlet. Kemampuan ini dapat distimulasi melalui menari, bergerak, pantomim. Anak dapat bermain dengan gerakan tubuh.

6. Kemampuan Mencintai Keindahan Alam (naturalist intelligence)

Yaitu kemampuan yang mengenali bentuk-bentuk alam disekitar kita, kemampuan ini dapat distimulasi melalui observasi lingkungan, bercocok tanam, memelihara binatang. Anak dapat bermain dengan tumbuhan, hewan dan fenomena alam.

7. Kemampuan berkawan (interpersonal intelligence)

Yaitu kemampuan untuk berinteraksi dengan orang lain. Kemampuan ini dapat distimulasi melalui berteman, kerjasama peran, stimulasi konflik. Ini dapat dilakukan dengan anak bermain dengan temannya atau manusia lain.

8. Kemampuan berfikir (intrapersonal intelligence)

Yaitu kemampuan yang pada dasarnya berupa kemampuan dalam memahami diri sendiri. Kemampuan ini dapat distimulasi melalui bekerja sendiri, membaca dalam hari. Anak dapat bermain dengan pikiran dan perasaan sendiri.

\section{B. Ciri-Ciri Alat Permainan Edukatif (APE)}

Alat permainan edukatif untuk anak usia dini yang dimaksud yaitu alat permainan yang dirancang khusus untuk 
anak usia dini. Alat permainan tersebut dirancang berdasarkan kebutuhan untuk pengembangan potensi-potensi yang ada pada diri anak. Untuk itu alat permainan edukatif berbeda dengan alat permainan secara umumnya. Karena itu alat permainan untuk pendidikan anak usia dini memiliki beberapa ciri. Sebagaimana yang dikemukan oleh Zaman dkk, (2007) bahwa alat permainan edukatif untuk anak usia dini adalah:

\section{Ditujukan untuk anak usia PAUD atau TK}

Maksudnya alat permainan yang dibuat hendaknya digunakan untuk anak usia PAUD atau TK bukan untuk anak SD yang usianya berbeda dengan anak PAUD. Kalau tidak sesuai dengan tingkat usia anak tentu tidak tepat sasaran dan bahkan akan dapat menyalahi dari ketentuan untuk pengembangan aspek perkembangan anak. Misalnya Puzzle, jumlah kepingan puzzle yang diberikan kepada anak usia 3-4 tahun itu akan berbeda dengan jumlah kepingannya dengan usia 5-6 tahun. Anak usia 3-4 tahun itu jumlah kepingannya lebih sedikit dan ukurannya lebih besar dan sebaliknya untuk usia 5-6 tahun itu jumlah kepingannya lebih banyak dan ukurannya kecil.

\section{Berfungsi untuk pengembangan aspek-aspek perkembangan anak PAUD atau TK}

Alat permainan yang dirancang atau dibuat harus dapat mengembangkan aspek perkembangan yang ada pada anak usia dini. Untuk itu dalam pengembangan alat permainan edukatif harus paham tentang aspek perkembangan yang akan dikembangkan atau distimulus supaya APE nya tidak salah fungsi. Aspek-aspek yang dikembangkan adalah fisik (motorik halus dan kasar), emosi, sosial, bahasa kognitif, dan moral. APE yang dirancang untuk pengembangan kognitif hendaknya dapat digunakan untuk melatih daya nalar anak. APE seperti ini 
dirancang dengan rancangan tertentu baik dari segi bentu, ukuran, dan warnanya. APE seperti ini dirancang khusus, sehingga kalau anak salah menggunakannya dia menyadarinya dan akan dapat membetulkannya. Contoh Lotto warna dan puzzle.

3. Dapat digunakan dengan berbagai cara, bentuk, dan untuk bermacam tujuan aspek pengembangan atau bermanfaat multiguna.

Maksudnya APE yang dibuat hendaknya dapat dimainkan atau dipergunakan dengan berbagai cara dan juga dapat menghasilkan bentuk-bentuk yang merangsang anak untuk menemukan sesuatu yang baru. Selain itu, alat permainan tersebut harus memiliki fungsi ganda dalam pengembangan aspek perkembangan anak. Misalnya APE yang dibuat untuk pengembangan bahasa, namun APE tersebut tidak hanya pengembangan bahasa semata tapi harus bisa juga pengembanga fisik- motorik atau logika anak.

\section{Aman bagi anak}

APE yang dikembangkan atau dibuat hendaknya aman bagi anak, maksudnya saat anak memainkannya tidak membahayakan bagi anak. Aman dari segi bentuk secara keseluruhan misalnya, tidak tajam, tidak runcing, dan tajam yang dapat melukai anak. Dari segi bahan yang digunakan juga tidak berbahaya misalnya dapat menimbulkan keracunan.

\section{Dirancang untuk mendorong aktivitas dan kreativitas}

Maksudnya setiap APE yang dibuat hendaknya dapat membangun atau menghasilkan sesuatu. Dengan anak memainkan APE tersebut anak dapat berimajinasi dan berkreasi menghasilkan sesuatu. Misalnya bermain lego 
atau balok-balok. Berbeda dengan menonton TV atau mendengarkan radio yang membuat anak pasif yang hanya melihat atau mendengarkan saja.

\section{Bersifat konstruktif atau ada sesuatu yang dihasilkan}

Maksudnya adalah bahwa APE yang ditujukan untuk anak usia dini, saat anak memainkannya anak mendapatkan sesuatu bentuk yang baru dari APE tersebut. Dimana APE tersebut dapat ditata, disusun, di tumpuk, dijejer dan sebagainya. Seperti APE balok.

\section{Mengandung nilai pendidikan}

Setiap APE yang dibuat hendaknya mengandung nilai pendidikan. Untuk itu dalam pengembangan APE harus jelas aspek pengembangannya dan juga usia yang menggunakan. Karena kalau tidak jelas aspek apa yang akan dikembangkan tentu terjadi proses pendidikannya.

\section{Jenis Alat Permainan Edukatif}

Jenis Alat permainan untuk anak usia dini secara umum dapat dikelompokkan berdasarkan:

1). Penempatannya. Berdasarkan penempatan maka alat permainan edukatif ada dua yaitu alat permainan yang berada di luar ruangan dan alat permainan yang berada di dalam ruangan. Alat permainan yang berada di luar ruangan umumnya alat-alat permainan yang dalam kategori besar-besar. Seperti ayunan, pelosotan, putaran, papan titian, dan sebagainya. Alat permainan edukatif yang di luar ini lebih pada pengembangan kemampuan fisik dan motorik anak. Sedangkan alat permainan edukatif yang ada di dalam ruang itu dikatakan alat permainan edukatif yang kecil. Maka pembagian alat permainan berdasarkan penempatan ini dapat diatur secara area atau sentra. 
2). Tujuan dan aspek perkembangan. Pada jenis yang kedua ini alat permainan dikelompokkan berdasarkan kegunaannya dan tujuan pengembangan. Jadi APE akan dikelompokan berdasarkan aspek perkembangan anak, seperti untuk perkembangan bahasa, kognitif, fisik-motorik, sosial dan lain sebagainya

3). Pembagian APE berdasarkan pendapat ahli. Menurut Zaman dkk, (2005), Pengembangan APE menurut ahli ini dapat dikelompokkan berdasarkan penciptanya yaitu Dr. Maria Montessori, George Cruissenaire, Peabody, dan Proebel. Berdasarkan ciptaan para ahli ini maka ditentukanlah jenis-jenis APE untuk anak PAUD dan TK yang ada di Indoneia, yaitu:

\section{APE untuk kemampuan berbahasa}

Menurut Sudono, (2000) APE yang dikembangkan oleh Elizabeth Peabody yaitu boneka tangan yang berfungsi sebagai tokoh mediator yaitu tokoh P. Mooney dan Joey. Boneka tersebut dilengkapi dengan papan magnet, gambargambar dan piringan hitam berisi lagu, dan tema cerita serta kantong pintar sebagai pelengkap. Perangkat permainan Peabody ini memiliki sifaat yang sangat mendasar sehingga dapat digunakan dalam setiap ragam budaya.

Sekarang ini sudah banyak pengembangan dari APE ini, sudah banyak bentuk karakter boneka yang ditampilkan dan bahkan ada juga pengembangannya dalam bentuk boneka jari. Walaupun yang ditampilkan bukan tokoh Moeeny dan Joey, tapi pengilhami dari bentuk-bentuk APE boneka yang ada sekarang adalah dari tokoh tersebut. Boneka tangan yang dikembangkan di PAUD atau di TK sekarang ini dilengkapi dengan panggung dan dilengkapi dengan layar yang bisa diganti-ganti. 


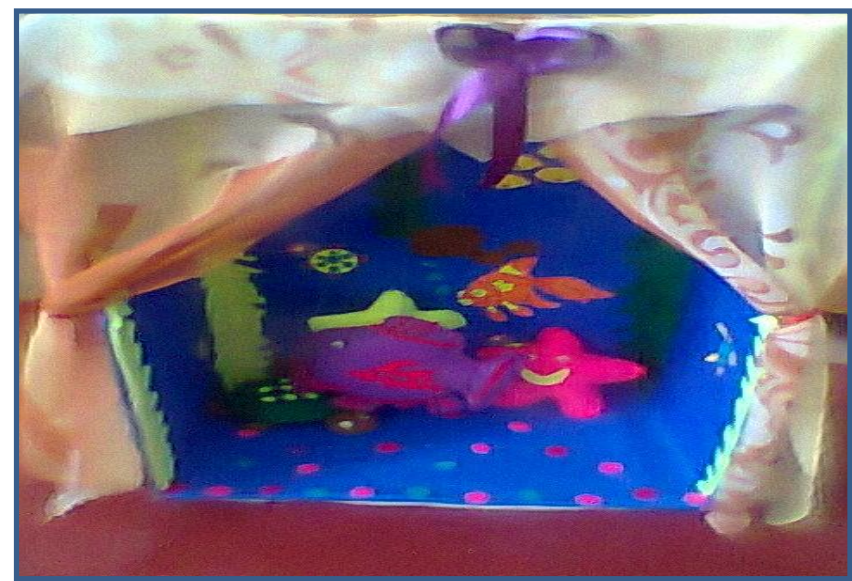

Gambar: 4 Panggung Boneka
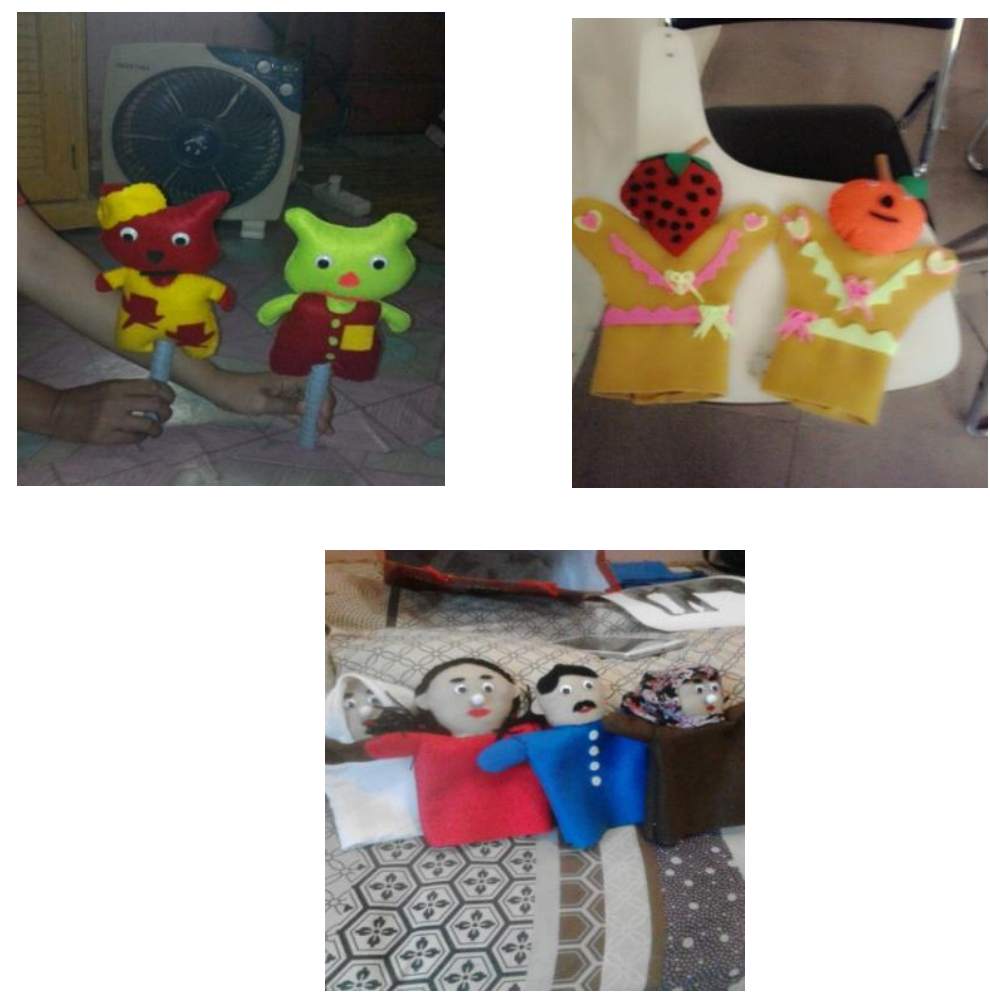

Gambar 5 Pengembangan Berbagai Bentuk Boneka Tangan 


\section{APE Ciptaan Montessori}

Dr. Maria Montessori menciptakan alat permainan edukatif (APE) yang memudahkan anak mengingat konsepkonsep yang akan dipelajari tanpa perlu bimbingan sehingga memungkinkan anak bekerja secara mandiri. Montessori merancang APE lebih mengutamakan pada prinsip anak belajar secara mandiri karena APE yang diciptakannya lebih menuntut anak untuk berfikir dan mandiri. Contoh APE ciptaan montessori adalah puzzle geometri, Berbagai bentuk Geometri, Papan bidang I dan II

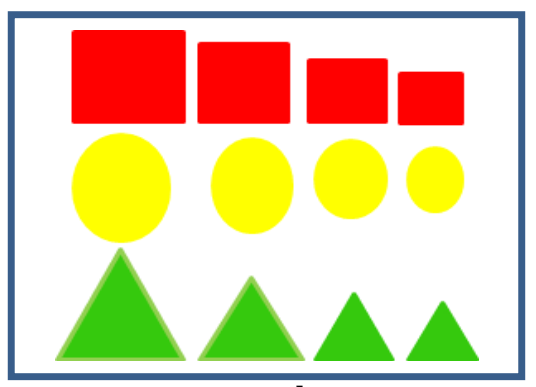

Papan Bidang I

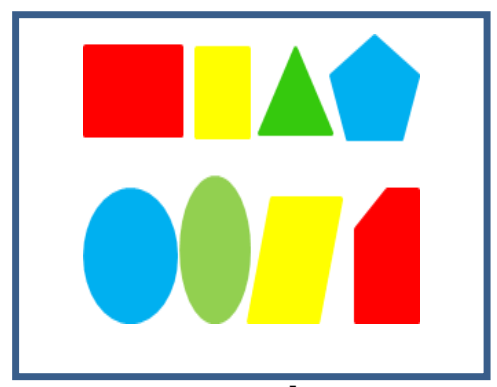

Papan Bidang II

Gambar 6 : Papan Bidang I dan II

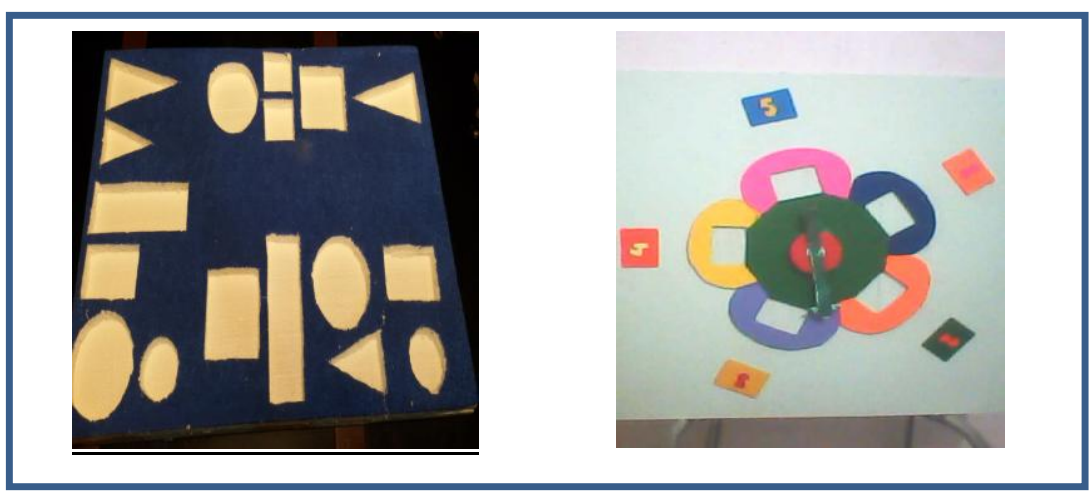

I

II

Gambar 7: Pengembangan Papan Geometri dan Puzzle 


\section{APE Geogle Cruissenaire}

Geogle Cruissenaire menciptakan balok Cruissenaire untuk mengembangkan kemampuan berhitung pada anak, pengenalan bilangan dan untuk meningkatkan kemampuan bernalar. Balok yang dikembangkan Cruissenaire cukup banyak dikembangkan pada lembaga-lembaga pendidikan anak usia dini di PAUD maupun TK. Yang diciptakan Cruissenaire terkenal dengan balok berserinya yang ukurannya yaitu:

1x1x1 cm dengan warna kayu asli

$2 \times 1 \times 1 \mathrm{~cm}$ dengan warna merah

$3 \times 1 \times 1 \mathrm{~cm}$ dengan warna hijau muda

$4 \times 1 \times 1 \mathrm{~cm}$ dengan warna merah muda

$5 \times 1 \times 1 \mathrm{~cm}$ dengan warna kuning

$6 \times 1 \times 1 \mathrm{~cm}$ dengan warna hijau tua

$7 \times 1 \times 1 \mathrm{~cm}$ dengan warna hitam

$8 \times 1 \times 1 \mathrm{~cm}$ dengan coklat

$9 \times 1 \times 1 \mathrm{~cm}$ dengan warna biru tua

$10 \times 1 \times 1 \mathrm{~cm}$ dengan warna jingga

Berdasarkan balok Cruissenaire inilah dikembangkan di PAUD-PAUD atau TK-TK. Walaupun yang balok-balok yang dikembangkan di PAUD/TK di Indonesia baloknya sudah dimodifikasi. Sebagaiman terlihat pada gambar: 8. 


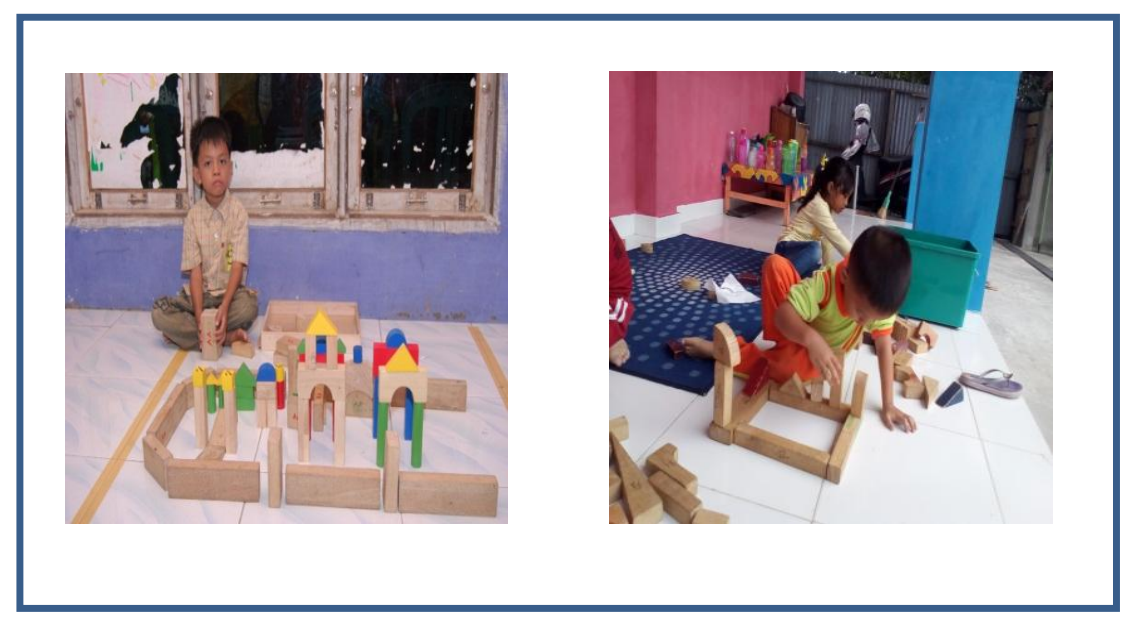

Gambar 8 Anak Sedang Memainkan Balok

\section{APE Ciptaan Froebel}

Menurut Zaman dkk, (2005) Froebel memiliki alat khusus yang dikenal dengan balok Blockdoss. APE ini berupa balok bangunan, yaitu suatu kotak besar berukuran 20x30 cm yang terdiri dari balok-balok kecil berbagai ukuran yang merupakan kelipatannya. Di Indonesia blockdoss dikenal dengan kotak kubus dalam pendidikan AUD/TK. APE ini banyak digunakan sebagai salah satu jenis APE untuk melatih motorik dan daya nalar anak.

Selain APE yang pengelompokkan APE yang sudah diuraikan di atas masih banyak jenis APE lainnya. Yang sudah dikembangkan pada pendidikan anak usia dini di Indonesia. Pengembangan APE tergantung pada kreativitas pendidik dalam menyediakannya. 
40 Media Pembelajaran Anak Usia Dini 


\section{BAB IV \\ PENGEMBANGAN MEDIA PEMBELAJARAN BAGI ANAK USIA DINI}

\section{A. Media, Sumber Belajar, dan APE Berbasis Budaya}

Pembelajaran berbasis budaya merupakan suatu bentuk pembelajaran yang bertujuan menginformasikan kepada anak didik mengenai kebudayaan yang ada dan berkembang dilingkungannya. Pembelajaran berbasis budaya merupakan strategi penciptaan lingkungan belajar dan perancangan pengalaman belajar yang mengintegrasikan budaya sebagai bagian dari proses pembelajaran, Sutarno (Hadi sutanto, 2018).

Kebudayaan yang dimiliki senantiasa diwariskan supaya kebudayaan tersebut tidak pudar dan hilang sejalannya bergantinya waktu. Pengenalan budaya pada anak usia dini dapat dilakukan dengan penggunaan media-media pembelajaran yang bernuansa kepada budaya setempat. Karena kebudayaan itu merupakan mengenal ruang dan tempat tumbuh kembangnya manusia, dengan mengalami perubahan, penambahan dan pengurangan, Hadi Susanto, (2000).

Penanaman kebudayaan akan terjadi secara enkulturasi yaitu proses penlaziman secara sadar atau tidak sadar yang dilakukan dalam batas-batas yang diizinkan oleh suatu kebudayaan. Menurut Herskovis Manan, (1989), proses ekulturatif bersifat kompleks dan berlangsung seumur hidup, tetapi proses itu berbeda-beda pada berbagai tahap dalam lingkaran kehidupan seseorang. Ini menunjukkan bahwa ekulturasi dimulai dari awal usia dini.

Indonesia memiliki beragam budaya yang terbentang dari Sabang sampai Meraoke. Tiap-tiap daerah memiliki budaya yang sangat unik dan khas sesuai dengan penganutnya. Salah 
satu budayanya adalah budaya Melayu Riau. Budaya Melayu sebagai salah satu kekayaan budaya daerah di Indonesia mencerminkan peradapan kehidupan masyarakat Melayu. Budaya Melayu memiliki berbagai karya yang mencerminkan pemikiran, perilaku, aturan, dan tuntunan dalam menjalani kehidupan baik secara individu maupun sosial. Tatanan kehidupan dalam budaya Melayu tersebut mengandung nilainilai luhur sehingga budaya Melayu merupakan budaya yang adil dan budaya Melayu merupakan suatu hal yang harus dikembangkan melalui pendidikan, agar segala norma, sopan santun, adat istiadat, dan lainnya dapat tersampaikan kepada generasi lainnya dengan pendidikan tersebut.

Pendidikan budaya sangatlah penting dan harus dimulai sejak anak usia dini karena agar perkembangan anak dapat terpenuhi secara maksimal. Aspek yang berkembang dalam pembelajaran budaya adalah moral dan agama kognitif, bahasa, motorik kasar, dan halus, seni dan sosial emosional. Pengetahuan mengenai budaya sangatlah perlu dilakukan terutama budaya daerah itu sendiri yakni budaya melayu. Pengenalan budaya sejak dini memberikan edukasi kepada anak tentang keberagaman budaya yang harus saling dihargai sehingga norma dan nilai budaya bangsa akan dapat terwariskan pada generasi selanjutnya. Penerapan pendidikan budaya Melayu terhadap generasi penerus, perlu kiranya dirujuk konsep pendidikan yang sedang dan akan dikembangkan di tanah air kita dan juga di Riau. UU No 20 tahun 2003 pasal 36 ayat 3 tentang pendidikan nasional menetapkan tentang strategi, program, serta kebijakan pendidikan supaya berhasil guna untuk menuju pendidikan manusia bermutu. UU memberikan kesempatan kepada daerah untuk membekali anak didiknya melalui materi muatan lokal. Adapun kearifan lokal menurut Guslinda (Jurnal Figur, 2017: 
hlm, vol. no), mengatakan bahwa kearifan lokal lahir dan terjadi dalam budaya yang diciptakan dan digunakan secara bijaksana oleh manusia untuk selalu memaknainya. Sehingga nilai-nilai tersebut akan bertahan dan selalu berusaha diwariskan dari generasi kegenerasi. Sebagaimana yang terdapat dalam UU No.32 tahun 2009 tentang perlindungan dan pengelolaan lingkungan hidup Bab I Pasal 1 butir 30 Kearifan lokal adalah nilai-nilai luhur yang berlaku dalam tata kehidupan masyarakat untuk antara lain melindungi dan mengelola lingkungan hidup secara lestari.

Berdasarkan paparan di atas, pendidikan budaya Melayu sangatlah penting adanya bukan hanya sebagai pelestarian bagi bangsa namun pembelajaran budaya Melayu juga dapat meningkatkan aspek perkembangan bagi anak usia dini.

\section{Aspek Perkembangan Anak Usia Dini Dalam Pendidikan Budaya Melayu}

Secara harfiahnya perkembangan anak selalu dipengaruhi oleh budaya tempat anak dilahirkan dan dibesarkan. Anak yang lahir dan besar di daerah Melayu tentu akan tumbuh dan berkembang sesuai dengan budaya yang diterimanya. Budaya Melayu menurut Hendrik, dkk, (2005), bahwa kebudayaan Melayu inilah yang seharusnya dijadikan "Jati diri " masyarakatnya, dan kebudayaan ini juga yang dijadikan sandaran dalam mengambil kebijakan pembangunan, pergaulan, dan sebagainya. Berdasarkan dari pendapat di atas jelaslah bahwa kebijakan-kebijakan yang digunakan dan ditetapkan dalam masyarakat budaya Melayu hendaknya bersandar dan bertolak kepada budaya Melayu. Begitu juga dengan pendidikan khususnya pendidikan anak usia dini. 


\section{Media Pembelajaran Anak Usia Dini}

Perlu kita ketahui segala bentuk pembelajaran akan meningkatkan aspek perkembangan dalam diri anak didik. Salah satunya pendidikan budaya Melayu yang dapat meningkatkan aspek-aspek perkembangan secara maksimal seperti:

a. Aspek nilai agama dan moral

b. Aspek sosial emosional

c. Aspek fisik motorik

d. Aspek kognitif

e. Aspek bahasa

f. Aspek seni

Aspek-aspek tersebut merupakan aspek yang harus dipenuhi oleh setiap individu terutama bagi peserta didik yaitu anak usia dini, pada usia tersebut proses pertumbuhan aspek berlangsung sangat pesat dan cepat. Maksimal tidaknya suatu aspek perkembangan tersebut tergantung pada bagaimana cara guru dalam menggunaka media tersebut agar tujuan dari media tersebut dapat tersalurkan pada peserta didik secara maksimal.

\section{Pendekatan dan Metode Pendidikan Budaya Melayu Pada Anak Usia Dini.}

Metode dan pendekatan seringkali digunakan secara bergantian, bahkan keduanya seringkali dikaburkan atau disamakan dalam penggunaannya. Keduanya sebenarnya memiliki sedikit perbedaan yang bisa dijadikan untuk memberikan penegasan bahwa kedua istilah tersebut memang berbeda. Menurut Kamus Umum Bahasa Indonesia karangan W.J.S. Poerwadarminta edisi III (2007) pendekatan memiliki arti hal (perbuatan, usaha) mendekati atau mendekatkan. Sedangkan menurut Kamus Bahasa Inggeris arti pendekatan adalah jalan untuk melakukan sesuatu (John M. Echols, 2002). 
Berdasarkan dua arti tersebut dapat dipahami bahwa pendekatan setidaknya mengandung unsur sebagai suatu kegiatan yang meliputi: proses perjalanan waktu, upaya untuk mencapai sesuatu dan dapat pula memiliki ciri sebagai sebuah jalan untuk melakukan sesuatu. Terkait dengan hal tersebut di atas, tepat kiranya sebagai pendidik ataupun orang tua memahami bahwa untuk menyampaikan sesuatu pesan pendidikan diperlukan pemahaman tentang bagaimana agar pesan itu dapat sampai dengan baik dan diterima dengan sempurna oleh anak didik. Untuk mencapai ketersampaian pesan kepada anak didik tentunya seorang pendidik atau orang tua harus memiliki atau pun memilih keterampilan untuk menggunakan pendekatan yang sesuai dengan pola pikir dan perkembangan psikologi anak.

Ketepatan atau kesesuaian memilih pendekatan akan berpengaruh terhadap keberhasilan dalam penanaman nilai moral untuk anak usia dini. Sementara metode memiliki sedikit arti yang berbeda dengan pendekatan. Metode secara etimologi berasal dari bahasa Yunani metha dan hodos. Metha berarti di balik atau di belakang, sedangkan hodos berarti jalan. Jadi methahodos berarti disebalik jalan (Siswoyo dkk, 2005). Untuk saat ini metode diartikan sebagai tata cara. Pendekatan lebih menekankan pada proses berjalannya upaya untuk menyampaikan sesuatu, maka metode memiliki makna sebagai suatu cara kerja yang bersistem, yang memudahkan pelaksanaan suatu kegiatan guna mencapai tujuan yang telah ditentukan. Substansi perbedaan dari kedua istilah tersebut sangat tipis, yaitu hanya terletak pada cara kerjanya yang bersistem, yang berarti bahwa upaya itu merupakan suatu rangkaian yang teratur dan telah diperhitungkan serta teruji kehandalannya (Otib S. Hidayat, 2006). 
Pemilihan metode dan pendekatan yang dilakukan pendidik atau guru semestinya dilandasi alasan yang kuat dan faktor-faktor pendukungnya seperti karakteristik tujuan kegiatan dan karakteristik anak yang diajar. Karakteristik tujuan adalah pengambangan kognitif, pengembangan kreativitas, pengembangan bahasa, pengembangan emosi, pengembangan motorik, dan pengembangan nilai serta pengembangan sikap dan perilaku. Untuk mengembangkan nilai dan sikap anak dapat dipergunakan metode-metode yang memungkinkan terbentuknya kebiasaan-kebiasaan yang didasari oleh nilai-nilai agama dan moralitas agar anak dapat menjalani kehidupan sesuai dengan norma yang berlaku di masyarakat. Selain penentuan pendekatan berdasarkan tujuan kegiatan, karakteristik anak juga ikut menentukan metode yang digunakan dalam penanaman nilai.

Anak usia dini merupakan anak yang memiliki karakteristik suka bergerak (tidak suka diam), mempunyai rasa ingin tahu (curiosity) yang tinggi, senang bereksperimen dan menguji, mampu mengekspresikan diri secara kreatif, mempunyai imajinasi, dan senang berbicara. Anak memerlukan dan menuntut untuk bergerak yang melibatkan koordinasi otot kasar. Anak juga memerlukan kesempatan untuk menggunakan tenaga sepenuhnya saat melakukan kegiatan. Oleh karena itu, diperlukan ruang yang luas serta sarana dan prasarana (peralatan) yang memadai. Setiap guru akan menggunakan metode sesuai dengan gaya melaksanakan kegiatan. Tetapi yang harus diingat bahwa taman kanak-kanak memiliki cara yang khas. Oleh karena itu, ada metode-metode yang lebih sesuai bagi anak taman kanak-kanak dibandingkan dengan metode-metode lain. Misalnya saja guru TK jarang sekali yang menggunakan metode ceramah. Orang akan segera menyadari bahwa metode 
ceramah tidak sesuai dan tidak banyak berarti apabila diterapkan untuk anak TK.

Metode-metode yang memungkinkan anak dapat melakukan hubungan atau sosialisasi dengan yang lain akan lebih sesuai dengan kebutuhan dan minat anak. Melalui kedekatan hubungan guru dan anak, seorang guru akan dapat mengembangkan kekuatan pendidik yang sangat penting (Moeslichatun, 1998). Dalam pelaksanaan penanaman nilai pada anak usia dini banyak sekali metode dan pendekatan yang dapat digunakan oleh guru atau pendidik. Namun sebelum memilih dan menerapkan metode dan pendekatan yang ada perlu diketahui bahwa guru atau pendidik harus memahami benar metode atau pendekatan yang akan dipakai, karena ini akan berpengaruh terhadap optimal tidaknya keberhasilan penanaman nilai moral tersebut. Metode dalam penanaman nilai kepada anak usia dini sangatlah bervariasi dan metode ini dapat digunakan dalam penyampaian nilai budaya melayu pada anak usia dini, diantaranya bercerita, bernyanyi, bermain, bersajak, dan karya wisata.

\section{a. Bercerita}

Bercerita dapat dijadikan metode untuk menyampaikan nilai-nilai yang berlaku dalam masyarakat (Otib Satibi Hidayat, 2005). Dalam cerita atau dongeng dapat ditanamkan berbagai macam nilai moral, nilai agama, nilai sosial, nilai budaya, dan sebagainya. Kita mungkin masih ingat pada masa kecil dulu tidak segan-segannya orang tua selalu mengantarkan tidur anak-anaknya dengan cerita atau dongeng. Tidaklah mudah untuk dapat menggunakan metode bercerita ini. Dalam bercerita seorang guru harus menerapkan beberapa hal, agar apa yang dipesankan dalam cerita itu dapat sampai kepada anak didik. 
Beberapa hal yang dapat digunakan untuk memilih cerita dengan fokus moral, diantaranya: a) Pilih cerita yang mengandung nilai baik dan buruk yang jelas, b) Pastikan bahwa nilai baik dan buruk itu berada pada batas jangkauan kehidupan anak, c) Hindari cerita yang "memeras" perasaan anak, menakut-nakuti secara fisik (Tadzkiroatun Musfiroh, 2005). Dalam bercerita seorang guru juga dapat menggunakan alat peraga untuk mengatasi keterbatasan anak yang belum mampu berpikir secara abstrak. Alat peraga yang dapat digunakan antara lain, boneka, tanaman, benda-benda tiruan, dan lain-lain. Selain itu guru juga bisa memanfaatkan kemampuan olah vokal yang dimiliknya untuk membuat cerita itu lebih hidup, sehingga lebih menarik perhatian anak didik. Adapun teknik-teknik bercerita yang dapat dilakukan diantaranya: a) Membaca langsung dari buku cerita atau dongeng, b) Menggunakan ilustrasi dari buku, c) Menggunakan papan flanel, d) Menggunakan media boneka, e) Menggunakan media audio visual, f) Anak bermain peran atau sosiodrama. (Dwi Siswoyo dkk, 2005).

Strategi atau cara yang dapat digunakan ketika guru memilih metode bercerita sebagai salah satu metode yang digunakan, dalam penanaman nilai moral budaya melayu dengan menggunakan metode bercerita banyak kisah legenda dari kebudayaan melayu yang dapat disampaikan kepada anak secara baik dan menarik serta nilai yang terkandung dalan cerita kebudayaan melayu tersebut dapat meningkatkan aspek perkembangan pada anak baik secara kognitifnya anak tau cerita legenda melayu, dari segi bahasa anak dapat memperbanyak perbendaharaan kata, dari moral agamanya anak dapat menanamkan nilai budaya melayu dan masih banyak lagi. 


\section{b. Bernyanyi}

Pendekatan penerapan metode bernyanyi adalah suatu pendekatan pembelajaran secara nyata yang mampu membuat anak senang dan bergembira. Anak diarahkan pada situasi dan kondisi psikis untuk membangun jiwa yang bahagia, senang menikmati keindahan, mengembangkan rasa melalui ungkapan kata dan nada, serta ritmik yang menjadikan suasana pembelajaran menjadi lebih menyenangkan. Pesan pendidikan berupa nilai dan moral yang dikenalkan kepada anak tentunya tidak mudah untuk diterima dan dipahami secara baik. Anak tidak dapat disamakan dengan orang dewasa. Anak merupakan pribadi yang memiliki keunikan tersendiri. Pola pikir dan kedewasaan seorang anak dalam menentukan sikap dan perilakunya juga masih jauh dibandingkan dengan orang dewasa. Anak tidak cocok hanya dikenalkan tentang nilai dan moral melalui ceramah atau tanya jawab saja. Oleh karena itu, bernyanyi merupakan salah satu metode penamanan nilai moral yang tepat untuk diberikan kepada anak usia dini. Bernyanyi jika digunakan sebagai salah satu metode dalam penanaman moral dapat dilakukan melalui penyisipan makna pada syair atau kalimat-kalimat yang ada dalam lagu tersebut. Lagu yang baik untuk kalangan anak TK harus memperhatikan kriteria sebagai berikut: a) Syair/kalimatnya tidak terlalu panjang, b) Mudah dihafal oleh anak, c) Ada misi pendidikan, d) Sesuai dengan karakter dan dunia anak, e) Nada yang diajarkan mudah dikuasai anak (Otib Satibi Hidayat, 2005). 


\section{c. Bersajak}

Sajak diartikan sebagai persesuaian bunyi suku kata dalam syair, pantun, dan sebagainya terutama pada bagian akhir suku kata (Poerwadarminta, 2007). Pendekatan pembelajaran melalui kegiatan membaca sajak merupakan salah satu kegiatan yang akan menimbulkan rasa senang, gembira, dan bahagia pada diri anak. Secara psikologis anak taman kanak-kanak sangat haus dengan dorongan rasa ingin tahu, ingin mencoba segala sesuatu, dan ingin melakukan sesuatu yang belum pernah dialami atau dilakukannya. Melalui metode sajak guru bisa menanamkan nilai-nilai moral kepada anak. Sajak ini merupakan metode yang juga membuat anak merasa senang, gembira, dan bahagia. Melalui sajak anak dapat dibawa ke dalam suasana indah, halus, dan menghargai arti sebuah seni. Di samping itu anak juga bisa dibawa untuk menghargai makna dari untaian kalimat yang ada dalam sajak itu. Secara nilai moral, melalui sajak anak akan memiliki kemampuan untuk menghargai perasaan, karya serta keberanian untuk mengungkap sesuatu melalui sajak sederhana (Otib Satibi Hidayat, 2005).

\section{d. Karyawisa}

Karyawisata merupakan salah satu metode pengajaran di TK, anak mengamati secara langsung dunia sesuai dengan kenyataan yang ada, misalnya hewan, manusia, tumbuhan, dan benda lainnya. Dengan karyawisata anak akan mendapatkan ilmu dari pengalamannya sendiri dan sekaligus anak dapat menggeneralisasi berdasarkan sudut pandang mereka sendiri. Berkaryawisata mempunyai arti penting bagi perkembangan anak karena dapat membangkitkan minat anak pada sesuatu hal, dan memperluas perolehan informasi. Metode ini juga dapat memperluas 
lingkup program kegiatan belajar anak taman kanakkanak yang tidak mungkin dapat dihadirkan di kelas. Melalui metode karyawisata ada beberapa manfaat yang dapat diperoleh anak. Pertama, bagi anak karyawisata dapat dipergunakan untuk merangsang minat mereka terhadap sesuatu, memperluas informasi yang telah diperoleh di kelas, memberikan pengalaman mengenai kenyataan yang ada, dan dapat menambah wawasan anak. Informasi-informasi yang didapatkan anak melalui karyawisata dapat pula dijadikan sebagai batu loncatan untuk melakukan kegiatan yang lain dalam proses pembelajaran. Kedua, karyawisata dapat menumbuhkan minat tentang sesuatu hal, seperti untuk mengembangkan minat tentang dunia hewan maka anak dapat dibawa ke kebun binatang. Mereka mendapat kesempatan untuk mengamati tingkah laku binatang. Minat tersebut menimbulkan dorongan untuk memperoleh informasi lebih lanjut seperti tentang kehidupannya, asalnya, makannya, cara berkembang biaknya, cara mengasuh anaknya, dan lain-lain. Ketiga, karyawisata kaya akan nilai pendidikan, karena itu melalui kegiatan ini dapat meningkatkan pengembangan kemampuan sosial, sikap, dan nilai-nilai kemasyarakatan pada anak. Apabila dirancang dengan baik kegiatan karyawisata dapat membantu mengembangkan aspek perkembangan sosial anak, misalnya kemampuan dalam menggalang kerja sama dalam kegiatan kelompok. Keempat, karyawisata dapat juga mengembangkan nilai-nilai kemasyarakatan, seperti sikap mencintai lingkungan kehidupan manusia, hewan, tumbuhan, dan benda-benda lainnya. Karyawisata membantu anak memperoleh pemahaman penuh tentang 
kehidupan manusia dengan bermacam perkerjaan, kegiatan yang menghasilkan suatu karya atau jasa. Metode karyawisata bertujuan untuk mengembangkan aspek perkembangan anak taman kanak-kanak yang sesuai dengan kebutuhannya. Misalnya pengembangan aspek kognitif, bahasa, kreativitas, emosi, kehidupan bermasyarakat, dan penghargaan pada karya atau jasa orang lain. Tujuan berkarya wisata ini perlu dihubungkan dengan tema-tema yang sesuai dengan pengembangan aspek perkembangan anak taman kanak-kanak. Tema yang sesuai adalah tema binatang, pekerjaan, kehidupan kota atau desa, pesisir, dan pegunungan.

\section{Pengembangan Media Pembelajaran Berbasis Budaya}

Pengembangan media pembelajaran untuk anak usia dini dalam budaya Melayu Riau dapat dikembangkan mengacu pada beberapa budaya yang ada yaitu:

\section{a. Makanan}

Makanan sebagai bagian dari budaya Melayu sangat banyak ragamnya. Dari makanan yang beragam tersebut dapat dikembangkan menjadi media untuk pembelajaran anak usia dini. 
Nama Media : Minuman Laksamana Mengamuk

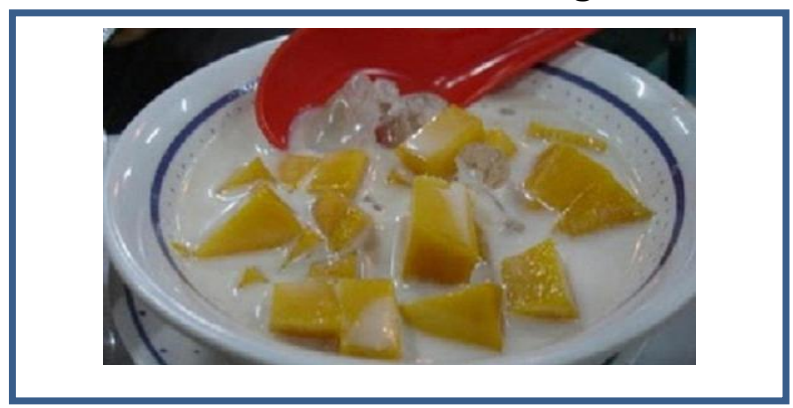

Gambar 9 Minuman Laksmana Mengamuk

Sasaran : Kelompok Usia 5-6 Tahun

\section{Kemampuan yang dikembangkan :}

1. Agama dan moral : Mempercayai adanya Tuhan melalui ciptaan-Nya.

2. Sosial Emosional : Memiliki perilaku yang mencerminkan sikap sabar (mau menunggu giliran untuk mengisi mangga yang diberikan oleh guru).

3. Bahasa : Menyampaikan tentang apa dan bagaimana ia membuat minuman laksamana mengamuk tersebut. Menggunakan anggota tubuh untuk pengembangan motorik kasar dan halus dalam mengisi kuah laksamana mengamuk ke dalam gelas.

4. Kognitif : Menghitung potongan mangga yang akan dimasukkan ke dalam gelas. Mengenal warna kuning sebagai daging buah mangga kuwini.

5. Seni : Anak mampu menjaga kerapian saat menuangkan santan ke dalam gelas

6. Motorik : Anak memotong mangga kuwini berbentuk persegi. Sudah bisa menyeimbangkan gelas agar minumannya tidak tumpah. 


\section{Bahan :}

1. Mangga Kuwini

2. Santan

3. Daun pandan

4. Garam secukupnya

5. Gula pasir

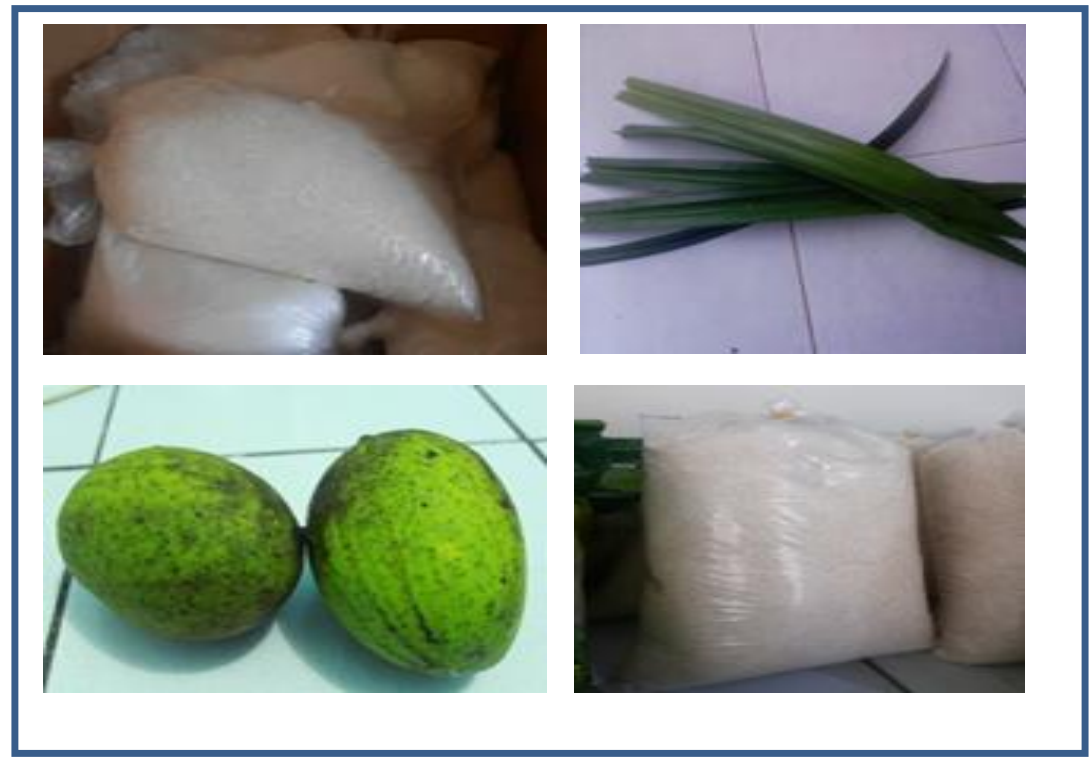

Gambar 10:

Bahan-hanan membuat minuman laksmana mengamuk

\section{Alat :}

1. Wajan

2. Gelas

3. Sendok

4. Pisau 


\section{Cara membuat :}

1. Untuk membuat kuah, rebus santan dengan campuran garam dan daun pandan yang sudah diikat lilit sambil diaduk sampai mendidih. Lalu Dinginkan.

2. Letakkan mangga di dalam gelas yang telah disediakan

3. Es laksamana mengamuk siap disajikan

\section{Cara Menggunakan :}

1. Guru terlebih dahulu menyiapkan alat dan bahan

2. Kemudian guru menjelaskan apa yang akan dibuat dan memperkenalkan semua alat bahan kepada anak.

\section{b. Permaianan}

Riau adalah daerah sangat kaya dengan berbagai jenis permainan rakyat. Baik itu permainan yang dimainkan oleh perorangan atau permainan yang dimainkan secara berkelompok. Permaianan rakyat yang beragam tersebut dapat dikembangkan untuk menjadi media, APE. Seorang guru dapat mengembangkan permainan-permainan yang ada dengan cara dikembangkan dan dikemas sesuai dengan aspek perkembangan anak dan tema pembelajaran. Diantara permainan yang ada pada masyakat Melayu Riau adalah permaianan statak.

Permainan setatak masih sering dimainkan .salah satu alasannya karna alatnya sederhana dan mudah didapat .disamping itu faktor gerak ,kelincahan dan keterampilan dalam menampilkan permainan juga menjadi daya tarik tersendiri bagi anak-anak. Hal inilah yang membuat permainan setatak terus berkembang di kalangan anak-anak. Permaina setatak ini sangat baik untuk perkembangan anak terutama perkembangan fisik motorik. Permaianan setatak 
dilakukakan sambil bermain, peserta juga melakukan kegiatan berjalan, melompat atau berjingkat dengan sebelah kaki, di samping itu, permainan ini juga keluwesan dan keterampilan dalam membawa atau menjunjung ucak(gacuk) dan melemparnya dengan cermat pada akotak yang di tuju . Pada bagian lain dalam permainan ini diperlukan ketajaman naluri karna peserta harus melakukan gerakan sambil memejamkan mata.Berdasarkan dari permaianan setatak ini maka dapat dikembangkan menjadi media pembelajaran bagi anak usia dini.

Pengembangan permainan statak dapat dikembangkan menjadi alat permainan Edukatif (APE), yang dimodifikasi sesuai dengan aspek perkembangan anak. Sebagaimana terlihat pada gambar,7 yaitu bentuk pola statak yang tradisional.

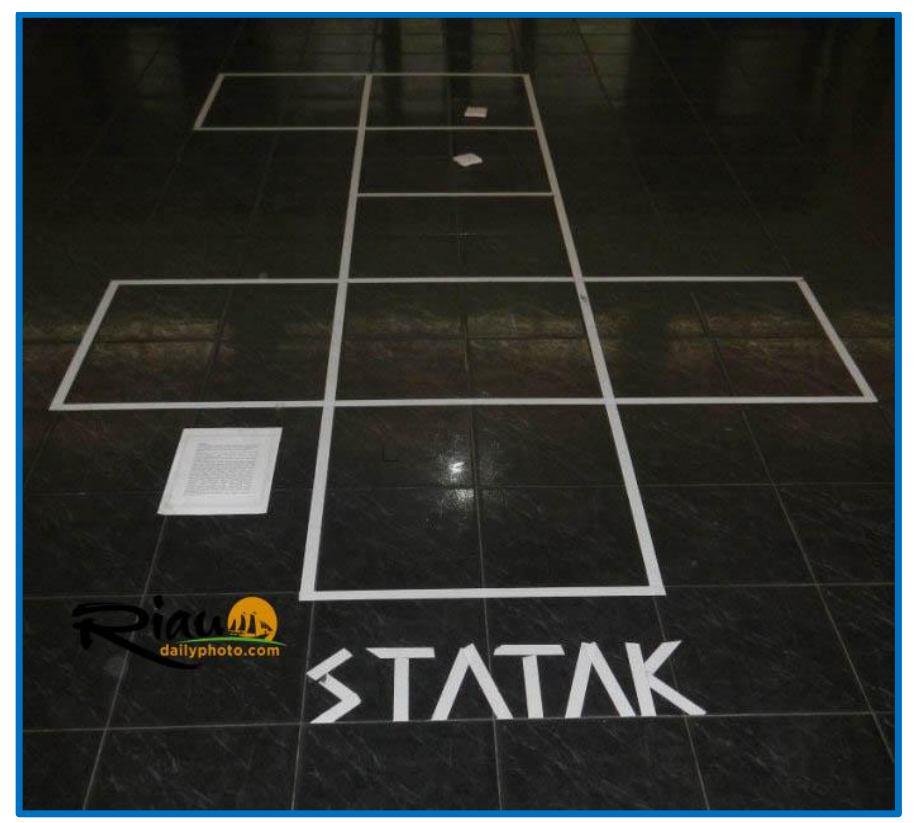

Gambar 11

Statak yang biasa dimainkan anak melayu (Koleksi dailly photo) 


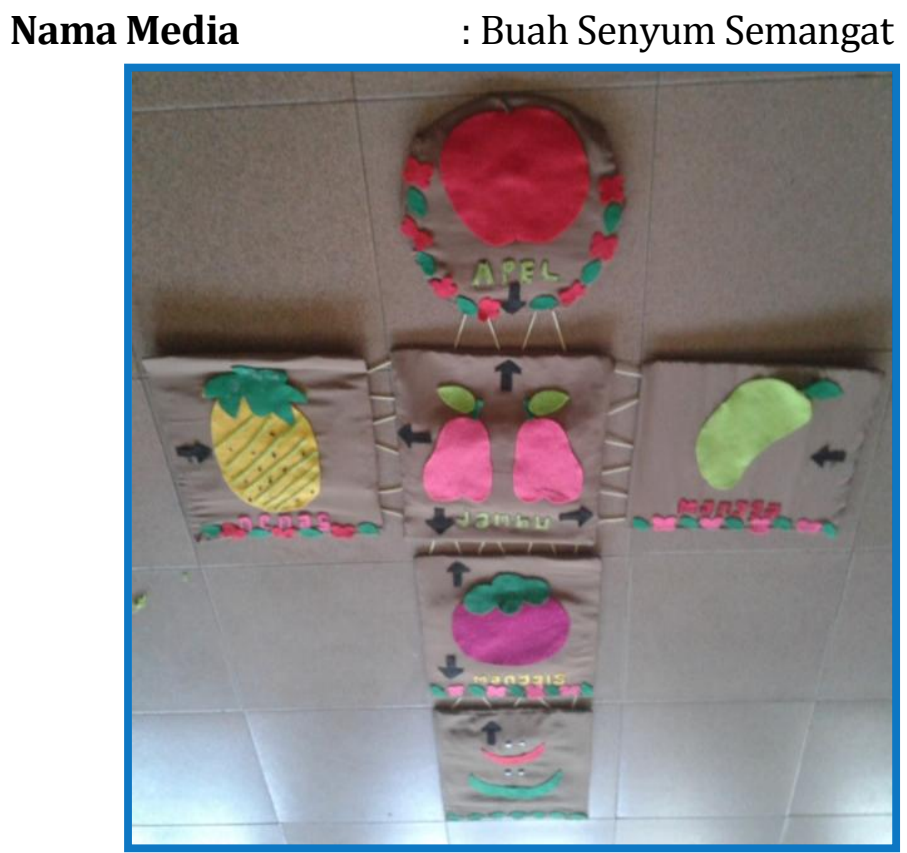

Gambar 12

APE yang dikembangkan dari permainan tradisional

\section{Sasaran : Usia 5-6 tahun}

\section{Kemampuan yang dikembangkan:}

1. Bahasa, anak dapat menyebutkan nama-nama buah yang ada di permainan.

2. Kognitif, anak dapat mempertimbangkan bagaimana gerakan melompat dalam memperagakan permaianan setatak anak akan dapat menyebutkan jenis dan nama serta warna-warna dari buah yang terdapat pada media. Selanjutnya anak juga dapat menghitung banyak buah dan mengelompokan dari gambar buah yang terdapat pada media. 
3. Fisik motorik

Permaian ini dapat mengasah perkembangan motorik kasar dan halus, dimana perkembangan motorik kasar terjadi saat anak melakukan kegiatan melompat dengan satu dan dua kaki saat memainnya. Anak dapat menggerakkan kedua kakinya tanpa terjatuh. Saat anak memegang dan menunjukan bentuk-bentuk buah yang ada akan dapat mengembangkan motorik halus anak. Stimulasi untuk motorik halus diperoleh saat anak menjemput mainannya, meraba, memegang dengan kelima jarinya, dan sebagainya. Sedangkan rangsangan motorik kasar didapat anak saat menggerak-gerakkan mainannya, melempar, mengangkat.

4. Sosial emosional

Permaianan yang dilakukan secara berdampingan dan berkelompok ini tentu akan dapat melatih kesabaran anak dalam menunggu giliran untuk memainkannya. Anak juga berlatih untuk mengulang-ulang kalau dia belum berhasil dalam melompat.

5. Nilai agama moral

Anak mengetahui buah adalah ciptaan Allah

6. Seni

Anak mengetahui berbagai macam-macam warna buahbuahan, mengikuti irama musik sebagai pengiring permaianan.

\section{Alat dan Bahan}

1 Gunting

2 Benang + jarum

3 Lem fox

4 Lem tembak

5 Tali kur

6 Kain puring 
7 Kain flannel

8 Pasir, ampas kelapa, kertas, kapas

9 Kain perca, serbuk kayu

10 Karton

\section{Cara membuatnya}

1. Tentukan ide dan kembangkan kedalam gambar rancangan

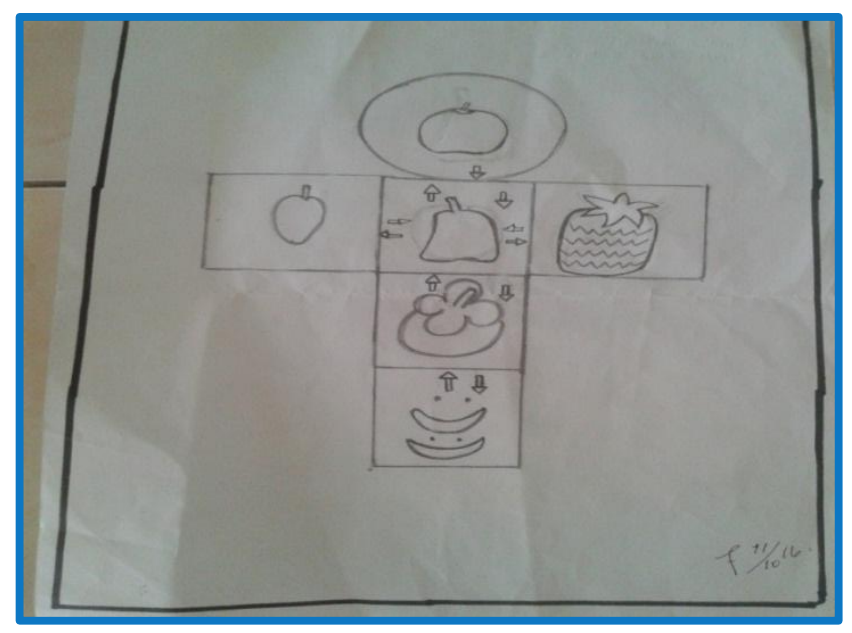

Gambar 13

Sket yang akan dijadikan APE

2. Buat pola global untuk bentuk permainan

3. Buat gambar-gambar untuk masing-masing kotak

4. Potong kertas karton sesuai ukuran yang ditentukan

5. Tempelkan karton pada kain puring dan potong sesuai dengan ukuran. 


\section{Media Pembelajaran Anak Usia Dini}

6. Jahit kain puring yang didalamnya sudah ada pola karton.

7. Isi masing-masing pola dengan pasir, ampas kelapa, kain perca atau serbuk kayu untuk mendapatkan tekstur yang berbeda.

8. Jahit lobang tempat memasukan bahan tekstur.

9. Pola-pola yang sudah siap dijahit ditempeli dengan gambar yang terbuat dari kain planel.

10. Setelah semua selesai lalu disatukan dengan dijahit menggunakan tali kur.

\section{Cara Bermain}

1. Anak mendengarkan penjelasan dari ibu guru

2. Guru membagi 5 orang anak untuk bermain

3. Guru menerangkan cara bermain permainan tersebut

4. Guru memutar musik dan anak melompati permainan sesuai irama

5. Anak bergiliran untuk memainkan permainan.

6. Permainan dilakukan secara berkelompok dan bergantian antar kelompok.

7. Anak melompat sesuai alur tanda panah dengan musik dan iram, sambil menyebutkan nama buah dikotak dia melompat.

\section{c. Benda transportasi}

Daerah Riau sebagian besar daerahnya adalah perairan dan juga tersebut dalam sejarah bahwa di tanah Melayu Riau pernah ada kisah Lancang Kuning yang mesti dikenalkan keanak didik sedari dini. Untuk anak dapat memahaminya maka dapat dijadikan sebagai media pembelajaran yang dikembangkan dalam kegiatan melipat. Pada media ini anak akan dapat mengenal nama, sejarahnya Melayu, cerita atau 
dikisahkan oleh gurua, dan anak juga akan dapat berkreativitas dengan kegiatan membuat lancangnya.

Nama Media : Membuat Kapal Lancang Kuning

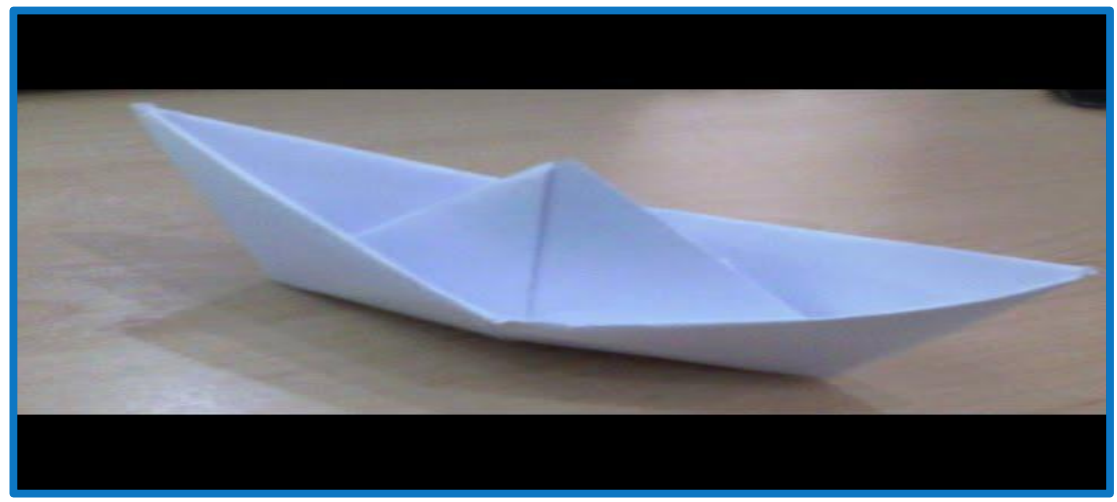

Gambar 14

Bentuk kapal atau lancang dari kertas

Sasaran : Kelompok Usia 4-5 Tahun

\section{Kemampuan yang dikembangkan :}

1. Agama dan Moral : Mempercayai adanya Tuhan melalui ciptaan-Nya.

2. Sosial emosional : Memiliki perilaku yang mencerminkan kemandirian dalam melipat kertas.

3. Bahasa : Menceritakan kembali apa yang sudah dibuatnya. Mengeja huruf "kapal"

4. Kognitif : Mengenal bentuk 2 dimensi (segitiga dan trapesium).

5. Seni : Mewarnai kapal lancang kuning dengan warna kuning.

\section{Bahan dan alat :}

1. Kertas 


\section{Media Pembelajaran Anak Usia Dini}

2. Gunting

\section{Cara membuat :}

1. Lipat kertas menjadi dua. Siapkan selembar kertas berbentuk persegi panjang dan letakkan di depan anda, secara memanjang dengan sisi yang lebih panjang terletak di samping kanan dan kiri. Lipat menjadi dua sama panjang dari atas ke bawah, sehingga lipatan terletak dibagian "atas" kertas

2. Lipat kertas menjadi dua dan buka lipatannya.

3. Lipat sudut atas kertas ke bawah

4. Balikkan kertas

5. Lipat sudut bawah ke atas

6. Balik kertas

7. Pegang bagian tengah topi ke atas

8. Tarik ujung kertas ke arah luar

9. Lipat bagian dasar wajib ke atas

10. Ulangi kembali

11. Pegang perahu kertas di tengah bagian dasarnya

12. Pegang sisi kanan dan bentuk segi tiga

13. Masukkan kapal ke dalam wadah yang telah berisi air

14. Kapal lancang kuning siap dilayarkan 

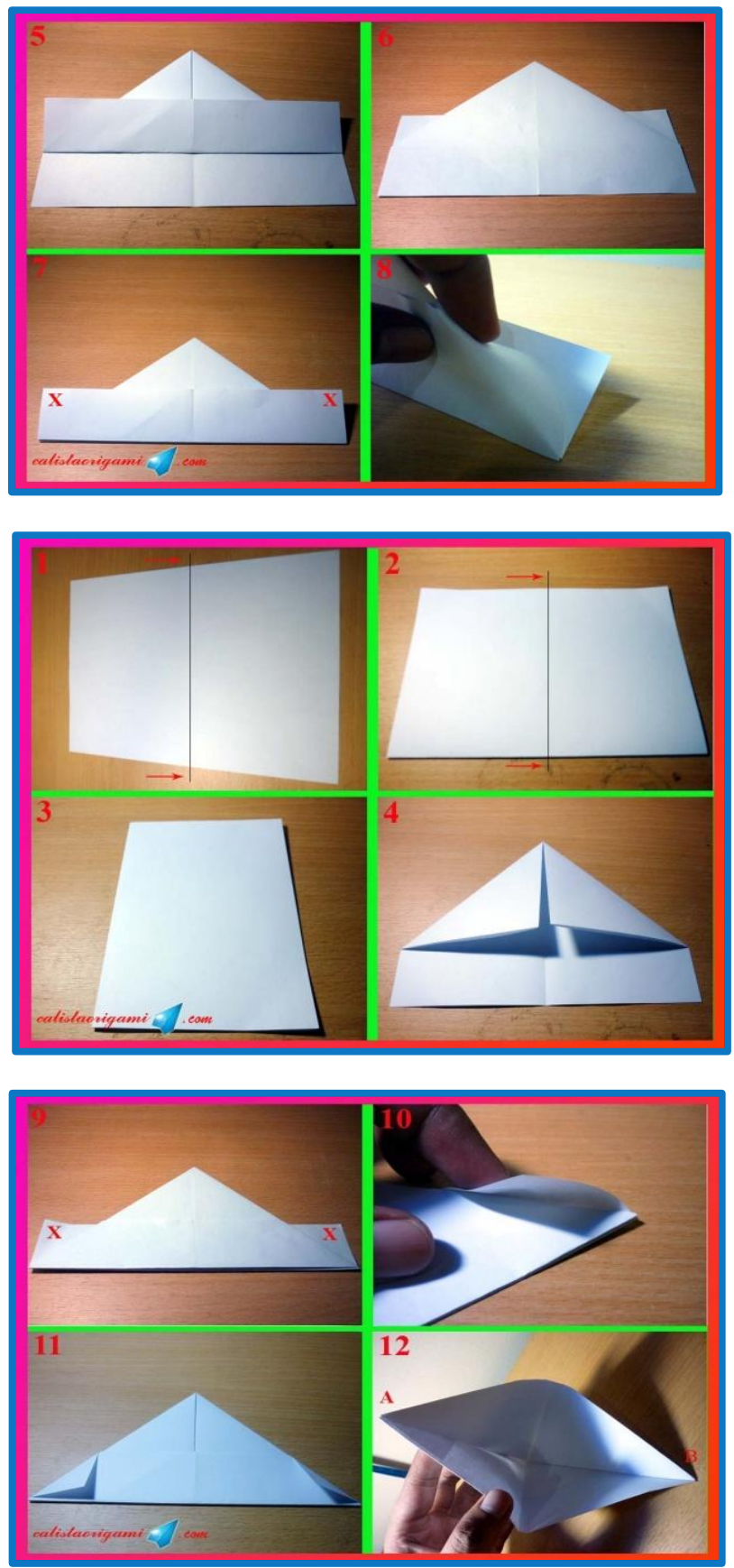


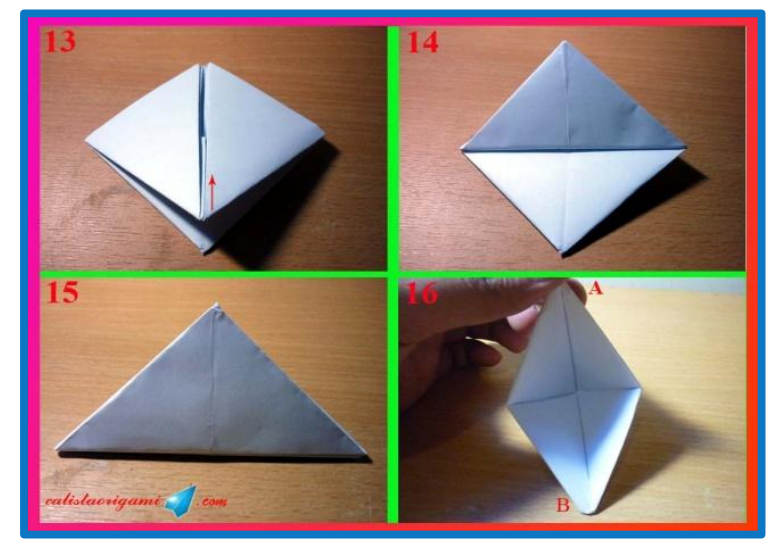

Gambar 15

Cara melipat menjadi bentuk lancang

\section{Cara Memainkan}

1. Sediakan air dalam wadah atau ember

2. Masukan kapal atau lancang kedalam wadah yang sudah berisi air.

3. Anak dapat memainkanya secara sendiri atau berkelompok.

\section{B. Media, Sumber Belajara dan APE Berbasis Lingkungan}

Pada dasarnya semua jenis lingkungan yang ada disekitar anak dapat dimanfaatka sebagai media, sumber belajar dan APE. Sepenjang lingkungan tersebut relevan dengan tema atau aspek perkembangan yang akan dikembangkan. https://id.wikipedia.org, (diakses 18 Agustus 2018), Lingkungan adalah kombinasi antara kondisi fisik yang mencakup keadaan sumber daya alam seperti tanah, air, energi surya, mineral, serta flora dan fauna yang tumbuh di atas tanah maupun di dalam lautan, dengan kelembagaan yang meliputi ciptaan manusia seperti keputusan bagaimana menggunakan 
lingkungan fisik tersebut. Lingkungan juga dapat diartikan menjadi segala sesuatu yang ada di sekitar manusia dan mempengaruhi perkembangan kehidupan manusia. Lingkungan sebagai sumber belajar dapat dikelompokan atas tiga yaitu:

\section{Lingkungan sosial}

Menurut Nana (2017), Lingkungan sosial sebagai sumber belajar berkenaan dengan interaksi manusia dengan kehidupan bermasyarakat. Lingkungan sosial sangat tepat digunakan untuk mempelajari dasar-dasar ilmu sosial dan kemanusian. Karena lingkungan sosial ini berkenaan dengan interaksi anak dalam kehidupan masyarakat. Menurut Badru dkk (2005), hal-hal yang bisa dipelajari anak PAUD/TK dalam kaitannya dengan pemanfaatan lingkungan sosial sebagai sumber belajar adalah:

1). Mengenal adat istiadat dan kebiasaan penduduk setempat dimana anak tinggal. Hal ini diperlukan agar anak sebagai anggota masyarakat dapat bergaul dan berinteraksi dengan lingkungan sosialnya sesuai dengan adat istiadat dan kebiasaan yang dianutnya.

2). Mengenal jenis-jenis mata pencarian penduduk disekitar tempat tinggal dan sekolah.

3) Mengenal organisasi-organisasi soasial yang ada dilingkungan tempat tinggal dan sekolah.

4) Mengenal kehidupan beragaman yang dianut oleh penduduk disekitar tempat tinggal dan sekolah.

5). Mengenal kebudayaan termasuk kesenian yang ada di sekitar tempat tinggal dan sekolah. 60 mengenal struktur pemerintahan setempat, seperti rukun tetangga (RT), RW, desa/kelurahan, dan kecamatan. 


\section{Lingkungan alam}

Menurut Sudjana dan Rivai, (2017) Lingkungan alam adalah segala sesuatu yang sifatnya alamiah, seperti sumber daya alam (air, hutan, tanah, batu-batuan), tumbuh-tumbuhan. Pemanfaatan lingkungan alam untuk sumber belajar dapat dilakukan dengan membawa anak berjalan-jalan (berkaryawisata) ketempat-tempat alam yang ditentukan, seperti Pantai, perkebunan, pergunungan dan sebagainya.

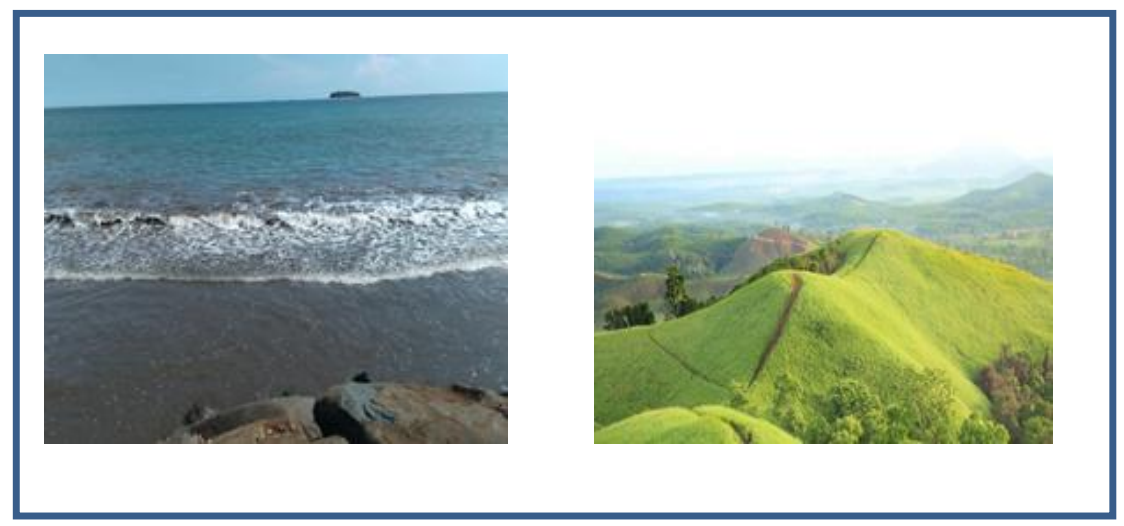

Gambar 16 Contoh Lingkungan Alam

\section{Lingkungan buatan}

Menurut lingkungan buatan yaitu lingkungan yang sengaja diciptakan atau dibangun manusia untuk tujuan-tujauan tertentu yang bermanfaat bagi kehidupan manusia. Sudjana dan Rivai (2017) menjelaskan bahwa lingkungan buatan itu adalah irigari atau pengairan, bendungan, pertamanan, kebun binatang, perkebungan, penghijauan dan pembengkit tenaga listrik.

Jenis-jenis lingkungan buatan yang sudah dikemukan tersebut dapat dijadikan sebagai sumber belajar bagi anak AUD/TK. 
Selanjutnya Sudjana dan Rivai (2017) mengatakan bahwa anak dapat mempelajari lingkungan buatan dari berbagai aspek, seperti: prosesnya, pemanfaatannya, fungsinya, pemeliharaannya, daya dukungnya serta aspek lain yang berkenaan dengan pembangunan dan kepentingan manusia dan masyarakat pada umumnya.

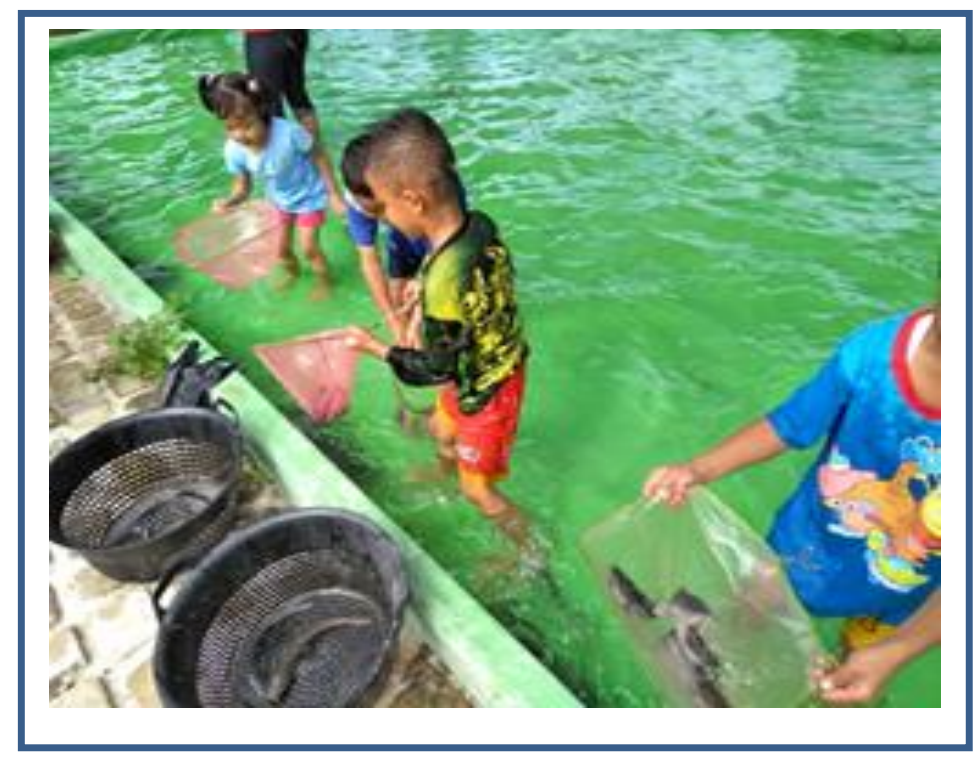

Gambar 17

Kolam Ikan Sebagai Sumber Belajar.

\section{Media, Sumber Belajar dan APE Berbasis Tema dan Aspek Perkembangan}

Pada pendidikan anak usia dini pengembangan media, sumber belajar dan APE juga dilakukan berdasarkan pada tema pembelajaran dan aspek perkembangan anak. Untuk pengembangan ini biasanya seorang guru dituntut untuk memahami pengembangan tema dan perkembangan anak. Guru harus paham berbeda tingkat usia anak tentu akan 


\section{Media Pembelajaran Anak Usia Dini}

berbeda pula cara pengembangannya. Pada PAUD/TK sudah ada kurikulum, yang didalamnya memuat tentang tema-tema yang akan dikembangkan dalam pembelajaran. Tema-tema yang terdapat dalam kurikulum tersebut adalah sebagai penggarah bagi guru dalam mengembangkan pembelajaran.

Dalam pengembangan pembelajaran guru dapat mengembangkan secara rinci atau spesifik sesuai dengan kebutuhan. Untuk itu seorang guru PAUD/ TK harus mampu mengembangkannya dalam RKT, RKB, RKM dan RKH sebagai pelaksanaan dari kurikulum tersebut. Pada RKH inilah sesorang guru PAUD/TK mengembangkan pembelajaran yang rumuskannya dari tema, diturunkan ke sub tema, dan dari subtema diturunkan ke sub-subtema seterusnya dikembangkan kegiatannya dalam RKH. Pada pelaksanaan RKH ini seorang guru harus menyertakan Media, Sumber belajar, atau APE, sesuai dengan sub-subtema yang dikembangkan.

Tema-tema yang ada dalam kurikulun PAUD/TK adalah sebagaimana terdapat pada tabel: 1 
TEMA, SUB TEMA DAN SUB-SUBTEMA PAUD/TK

\begin{tabular}{|c|c|c|c|c|c|c|c|}
\hline NO & TEMA & SUB TEMA & SUB-SUBTEMA & No & TEMA & $\begin{array}{l}\text { SUB } \\
\text { TEMA }\end{array}$ & SUB-SUBTEMA \\
\hline \multirow{13}{*}{1} & \multirow{13}{*}{ Diriku } & \multirow{3}{*}{ Tubuhku } & Bagian-bagian & \multirow{6}{*}{5} & \multirow{6}{*}{ Kendaraan } & \multirow{3}{*}{ Darat } & Sepeda motor \\
\hline & & & Fungsi & & & & Dokar \\
\hline & & & Cara merawat & & & & Mobil \\
\hline & & \multirow{3}{*}{ Kesukaanku } & Makanan & & & \multirow{2}{*}{ Air } & Perahu \\
\hline & & & $\begin{array}{l}\text { Kegiatan } \\
\text { bermain }\end{array}$ & & & & Kapal air \\
\hline & & & tempat & & & Udara & Pesawat terbang \\
\hline & & \multirow{4}{*}{ Identitasku } & Nam,Umur & \multirow{5}{*}{6} & \multirow{5}{*}{ Negaraku } & \multirow{2}{*}{$\begin{array}{l}\text { Lambang } \\
\text { Negara }\end{array}$} & Burung garuda \\
\hline & & & Nama orang tua & & & & bendera merah putih \\
\hline & & & Alamat & & & \multirow{2}{*}{$\begin{array}{l}\text { Lagu } \\
\text { Nasional }\end{array}$} & Lagu kebangsaan \\
\hline & & & Ciri-ciri & & & & Lagu wajib Nasional \\
\hline & & \multirow{3}{*}{ Keluargaku } & Anggota & & & Pahlawan & $\begin{array}{l}\text { Nama-nama } \\
\text { Pahlawan }\end{array}$ \\
\hline & & & Pekerjaan & \multirow{6}{*}{7} & \multirow{6}{*}{ Budayaku } & \multirow{2}{*}{ Pakaian } & Pakaian Nasional \\
\hline & & & Kegiatan & & & & Pakaian Daerah \\
\hline \multirow{9}{*}{2} & \multirow{9}{*}{ Binatang } & \multirow{3}{*}{ Unggas } & Burung & & & Makanan & Makanan Daerah \\
\hline & & & Ayam & & & Tarian & Tarian modern \\
\hline & & & Bebek & & & & Tarian Daerah \\
\hline & & & Kambing & & & $\begin{array}{l}\text { Permainan } \\
\text { Tradisional }\end{array}$ & Permainan Derah \\
\hline & & Ternak & Ayam & & & $\begin{array}{l}\text { Padi- } \\
\text { padian }\end{array}$ & Padi \\
\hline & & & sapi & & & & Jagung \\
\hline & & & Harimau & & & & Mangga \\
\hline & & Buas & Singa & 8 & $\begin{array}{l}\text { Tumbuh- } \\
\text { Tumbuhan }\end{array}$ & Buah- & Nangka \\
\hline & & & Badak & & & Buahan & Rambutan \\
\hline & & L & Wilayah Laut & & & & Pepaya \\
\hline 3 & $\begin{array}{l}\text { Lingkung } \\
\text { an }\end{array}$ & Ldut & Biota Laut & & & Umbi- & Ketela Pohon \\
\hline & & Gunung & Jenis Gunung & & & Umbian & Kentang \\
\hline
\end{tabular}



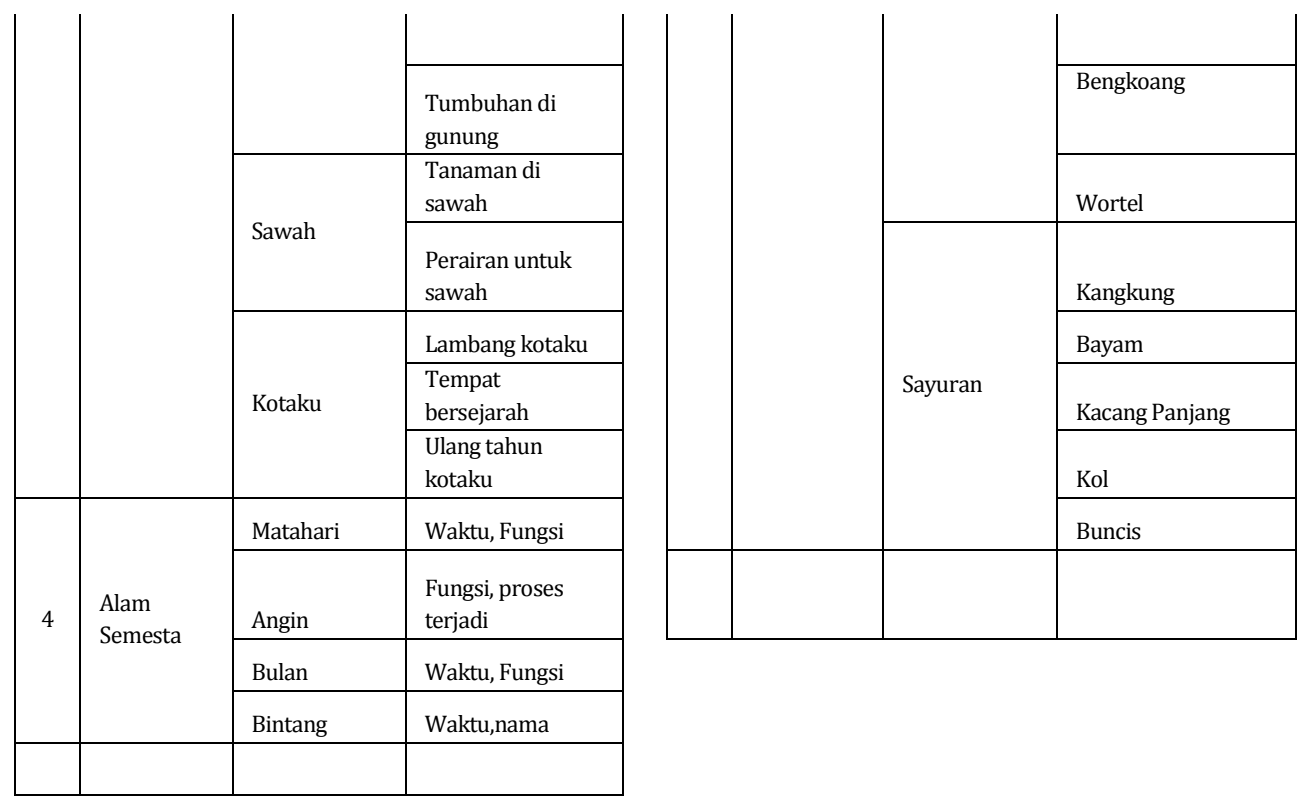

Pengembangan media, sumber belajar dan APE berdasarkan tema pembelajaran dapat dilakukan dengan menganalisis dan menentukan tema yang dikembangkan.

1. Pengembangan media, sumber belajar, dan APE dengan mengacu pada tema.
a. Tema I
: Diriku,
Sub Tema : Keluargaku
Sub-subtema: Anggota
Nama Media : Bingkai Keluarga 


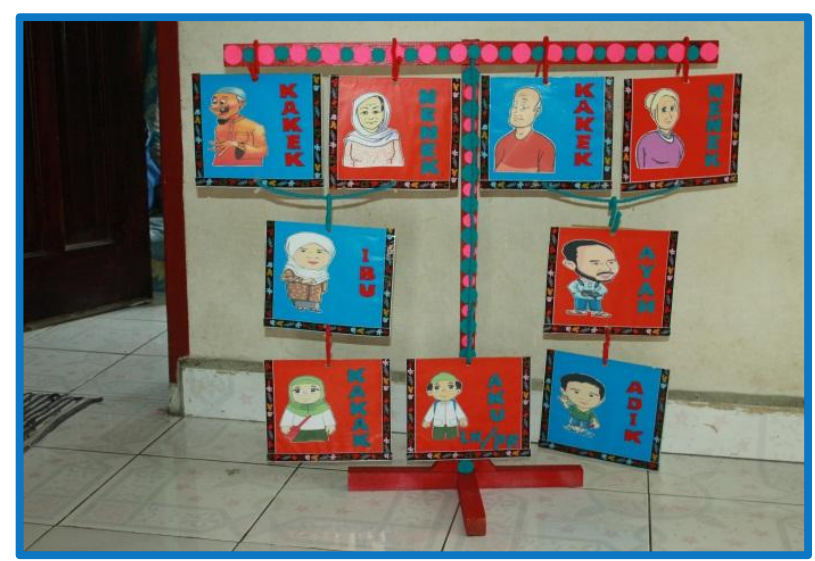

Gambar: 18 Bingkai Keluarga

Media untuk Tema I

Sasaran : Usia 5-6 tahun

\section{Kemampuan yang dikembangkan:}

1. Bahasa, anak dapat menyebutkan nama-nama anggota keluarga dan hubungannya antara angota satu dengan anggota lainnya.

2. Kognitif, anak dapat mempertimbangkan bagaimana menyusun dan memindahkan gambar-gambar anggota keluarga pada bingkai yang sudah disiapkan.

3. Fisik motorik

Permainan ini dapat mengasah perkembangan motorik kasar dan halus, di mana perkembangan motorik kasar terjadi saat anak melakukan mengambil dan memindahkan gambar pada bingkai yang sudah ditentukan. Anak juga berjalan dengan dua kaki saat memindahkannya motorik halus anak. Stimulasi untuk motorik halus diperoleh saat anak meraba dan menggenggam kartu atau gambar anggota keluarga. 
4. Sosial emosional

Permainan yang dilakukan secara sendiri atau berdampingan dan berkelompok akan dapat melatih kesabaran anak dalam menunggu giliran untuk memainkannya. Anak juga berlatih untuk mengulang-ulang kata dalam menyebutkan nama dari gambar kartu yang dipengangnya saat menunggu giliran memasangkannya pada bingkai yang disediakan.

5. Nilai agama moral

Anak mengetahui sisilah keluarga adalah ciptaan Allah

6. Seni

Anak mengetahui berbagai macam-macam warna dan gambar-gambar yang indah.

\section{Alat dan Bahan}

1. Gunting

2. Kawat jemuran

3. Lem fox

4. Lem tembak

5. Kayu

6. Kain flannel

7. Kayu reng $4 \times 6$

8. Karton

\section{Cara membuatnya}

1. potong kayu ukuran $50 \mathrm{~cm}$ satu buah, panjang $45 \mathrm{~cm}$ satu buah dan panjang 30 dua buah.

2. Buat stan untuk menggantungkan kartu

4. Buat gambar-gambar untuk anggota keluarga

5. Potong kertas karton sesuai ukuran untuk menempelkan gambar anggota keluarga.

6. Buat gantungan gambar dari kawat yang sudah disediakan 
7. Rangkai sesuai dengan urutan dan penempatan anggora keluarga

\section{Cara menggunakan:}

1. Guru menjelaskan tentang sisila keluarga

2. Guru membagi anak untuk berkelompok (3 orang anak) untuk bermain

3. Guru menjelaskan kegiatan yang dilakukan anak untuk memainkan bingkai bingkai keluarga.

4. Anak bermain secara bergiliran untuk memasangkan kartu sesuai dengan posisi dan urutan dalam keluarga

8. Anak bergiliran untuk memainkan permainan.

9. Permainan dilakukan secara berkelompok dan bergantian antar kelompok.

b. Tema II :

Nama Media : Chicken Alfabeth

Tema : binatang

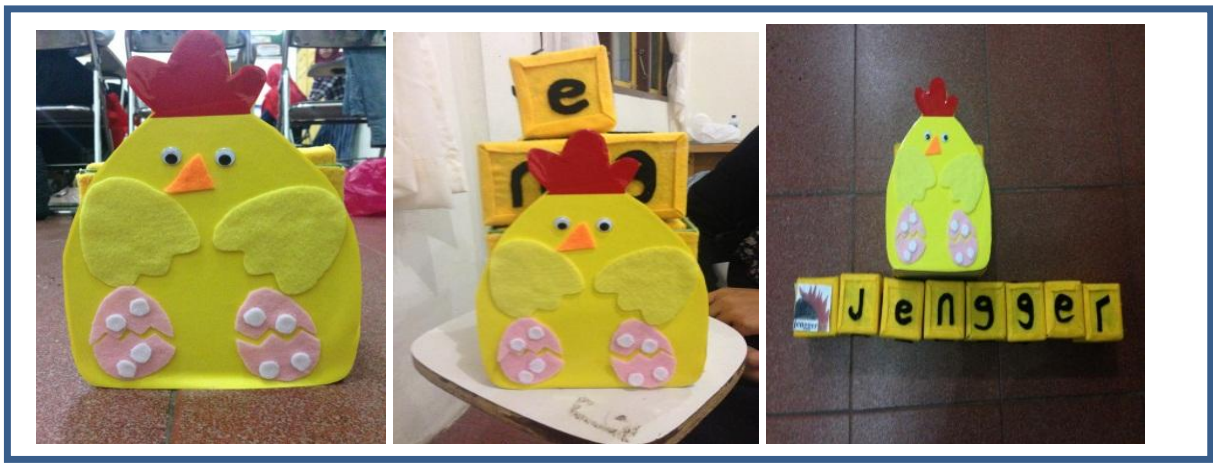

Gambar 19 Chicken Alfabet Media Untuk Tema Binatang 
Sasaran : Usia 5-6 tahun

\section{Kemampuan yang dikembangkan:}

1. Bahasa, anak dapat menyebutkan nama bagian-bagian dari ayam dan mengenal berbagai abjad yang digunakan.

2. Kognitif, anak dapat menyebutkan nama warna dan bentuk geometri atau balok yang digunakan dalam permainana chicken alfabeth.

3. Fisik motorik, Permainan ini dapat mengasah perkembangan motorik kasar dan halus, hal itu terjadi saat anak memegang dan mengenggam balok-balok huruf saat menyusun atau membuat kata dalam permainan. Stimulasi untuk motorik halus diperoleh saat anak meraba dan menggenggam kubus.

4. Sosial emosional, ketekunan dan kesabaran anak dalam menyusun dan menata balok-balok untuk mendapatkan sebuah kata atau nama yang berhubungan dengan ayam.

5. Nilai agama moral, anak dapat mengetahui dan mengenal ciptaan Allah dan bersyukur atas karunia yang diberikan Allah.

6. Seni, anak mengetahui berbagai macam-macam warna dan bentuk-bentuk yang indah.

Alat dan Bahan

1. Gunting

2. Lem

3. Pisau cutter

4. Kain planel

5. Papan trobos

6. Sticker

7. Karton

8. Gambar (jengger, paruh, sayap, ekor, ceker, telur dapat diambil dari gambar-gambar majala atau buku) 


\section{Cara Membuatnya}

1. Buatlah balok berukuran besar sebagai tempat balok kecil, lapisi dengan kain planel

2. Buatlah delapan balok dari karton, lalu tempel dengan kain planel, setelah balok kecilnya sudah terpotong tempellah huruf dari kain planel.

3. Pada bagian balok pertama, tempellah gambar bagianbagian ayam (ceker, sayap, paruh, jengger, telur, ekor)

4. Sebagai penghias dibagian depan, bentuklah pola menyerupai badan ayam, tempel dengan sticker, buat gambar telur dibagian depan

\section{Cara Menggunakan}

1. Guru menjelaskan tentang ayam dan bagian-bagian ayam yang lazim dikenal anak.

2. Guru menentukan gambar bagian-bagian ayam ( ceker, sayap, paruh, jengger, telur, ekor)

3. Guru menyuruh anak menyusun balok-balok huruf untuk membuat kata sesuai gambar yang ditampilkan.

4. Anak melakukan penyusunan secara bergantian.

\section{Pengembangan media, sumber belajar, dan APE dengan} mengacu pada aspek perkembangan anak

Untuk pengembangan berdasarkan aspek perkembangan seorang guru dituntut untuk dapat menentukan aspek apa yang akan dikembangkan sebelum menciptakan media, sumber belajar atau alat permainan edukatif (APE). Aspek perkembangan yang mesti dikembangkan pada anak usia dini diantaranya adalah: Fisik-motorik, kognitif, bahasa, sosial-emosional, kinestetik, moral nilai agama dan lainnya. Namu perlu diketahui bahwa dalam pembuatan media, 
sumber belajar atau APE untuk anak usia dini untuk pengembangan suatu aspek perkembangan, maka tidak satu aspek itu yang dikembangkan tapi akan juga dapat mengembangkan aspek-aspek yang lainnya. Ini disebabkan antara satu aspek perkembangan dengan yang lainnya saling berhubungan. Apek yang akan dikembangkan adalah aspek bahasa, namun APE yang dibuat untuk aspek bahasa akan ikut juga untuk aspek fisik-motorik atau yang lainnya.

Untuk itu apabila seorang guru merancang suatu APE untuk aspek tertentu secara tidak langsung APE yang dikembangkan akan dapat mengembangkan aspek yang lainnya. Hal ini disebabkan APE tersebut memiliki fungsi ganda atau multifungsi. Berikut ini akan dikemukan beberapa bentuk APE untuk pengembangan aspek tertentu yaitu:

\section{a. Pengembangan Bahasa}

\section{Nama APE : Alfabet Putar}

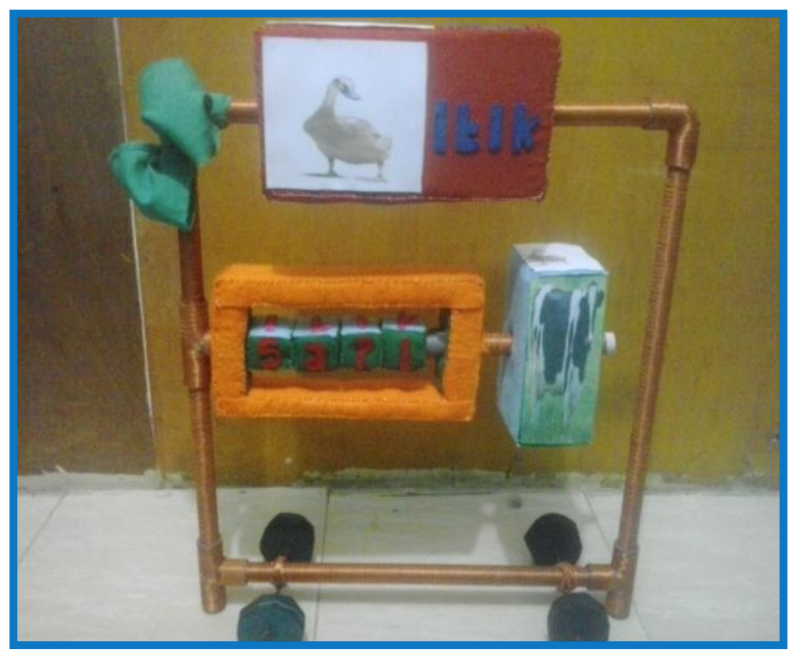

Gambar 20 Alfabet Putar untuk pengembangan bahasa 


\section{Aspek yang dikembangkan:}

1. Bahasa : anak mengetahui bermacam huruf

2. Kognitif : anak akan berusa mencari yang cocok

3. Sosial-emosional : anak sabar dalam mencari dan menyusun

4. Nilai agama moral : anak mengetahui bahwa buah ciptaan Allah

5. Fisik-motorik : anak dapat memutarkan balok

\section{Alat dan bahan:}

1. Gunting

2. Lem fox

3. Kain flanel

4. Kawat jemuran

5. Busa

6. Pita

7. Pipa air 2 inchi

8. Elbo

\section{Cara membuatnya:}

1. Potong pita berbentuk balok

2. Balut balok tersebut dengan kain

3. Potong pipa sesuai ukuran kemudian balut dengan pita

4. Sambungkan pipa tersebut dengan elbo/ penyambung pipa

5. Kemudian bolongkan balok dan susun menggunakan kawat

6. Disetiap sisi kubus besar ditempel gambar buah 
7. Kubus yang kecil ditempel huruf

8. Kemudian pasang lingkaran yang berguna sebagai roda

\section{Cara menggunakan:}

1. Anak memutar balok.

2. Setelah anak memutar balok anak akan melihat buahan apa yang ada.

3. Setelah anak meyusun huruf yang sesuai dengan gambar.

4. Sampai anak mendapatkan kata yang sesuai dengan gambar.

\section{Nama Media : : Dadu Putar Mahai Membaca}

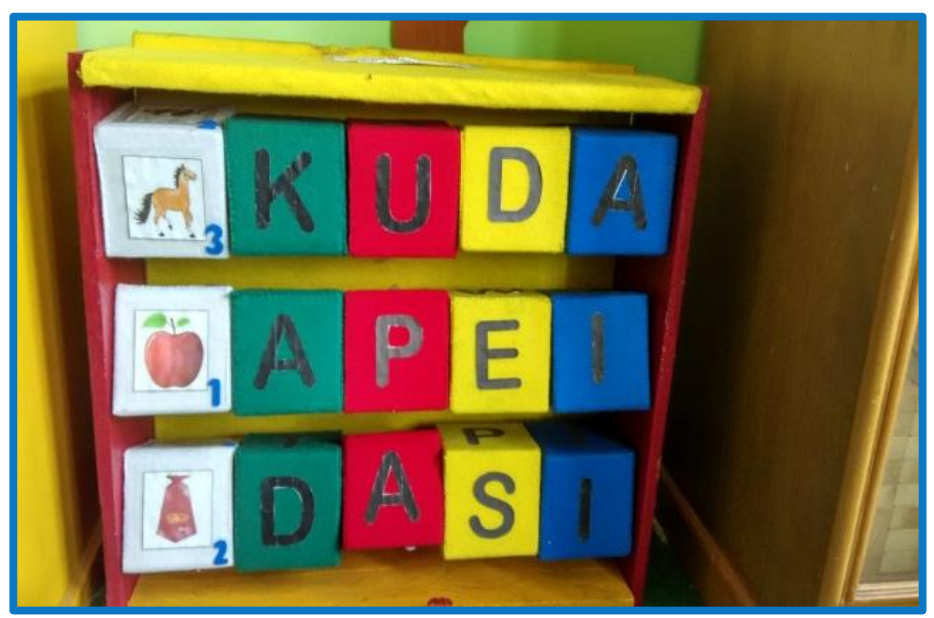

Gambar. 21 Untuk Pengembangan Bahasa 


\section{Aspek yang dikembangkan:}

1. Bahasa : anak mengetahui bermacam huruf

2. Kognitif : anak akan berusaha mencari yang cocok

3. Sosial-emosional : anak sabar dalam mencari dan memutar media

4. Nilai agama moral : anak mengetahui bahwa buah dan binatang ciptaan Allah

5. Fisik-motorik : anak dapat memutarkan balokbalok

\section{Alat dan bahan:}

1. Gunting

2. Palu

3. Gergaji

4. Paku

5. Pengaris/ $\mathrm{cm}$ meter

6. Lem fox

7. Kain flanel

8. 3 batang Stik kayu panjang $83 \mathrm{~cm}$

9. Papan

10. Karton trobos

11. Gambar binatang dan buah

\section{Cara membuatnya:}

1. Potong papan menjadi 4 potong ( 2 lebar $80 \mathrm{~cm}$ untuk lebar dan 2 panjang $60 \mathrm{~cm}$ untuk tinggi)

2. Pakukan papan membentu empat persegi panjang

3. Pasang stik dengan posisi melebar 
4. Buat balok-balok denga kertas trobos dengan ukuran $22 \times 22 \times 22 \mathrm{~cm}$ sebanyak 15 balok

5. Lobangi kubus sesuai diameter stik

6. Masing-masing sisi balok dilapisi kain planel dan ditempeli huruf dan gambar ( 3 balok untuk gambar dan 12 balok untuk ditempeli huruf)

7. Setelah selesai pengerjaan balok, lanjutkan dengan merangkai balok pada bidang empat persegi panjang

8. Masukan balok ke masing-masing stik sebanyak 5 balok untuk satu stik.

9. Stel dan finising.

\section{Cara mengunakan:}

1. Anak memutar balok,

2. Setelah anak memutar balok yang berisi gambar

3. Anak memutar balok yang berisi huruf dan mencari huruf yang sesuai dengan gambar yang ditampilkan.

4. Setelah anak dapat memutar dan menyusun sesuai dengan gambar dan huruf anak diminta membaca kata yang dibuatnya. 


\section{b. Pengembngan Kognitif}

Nama APE : Sempoa Fruit

Sasaran : Anak usia 5-6 tahun

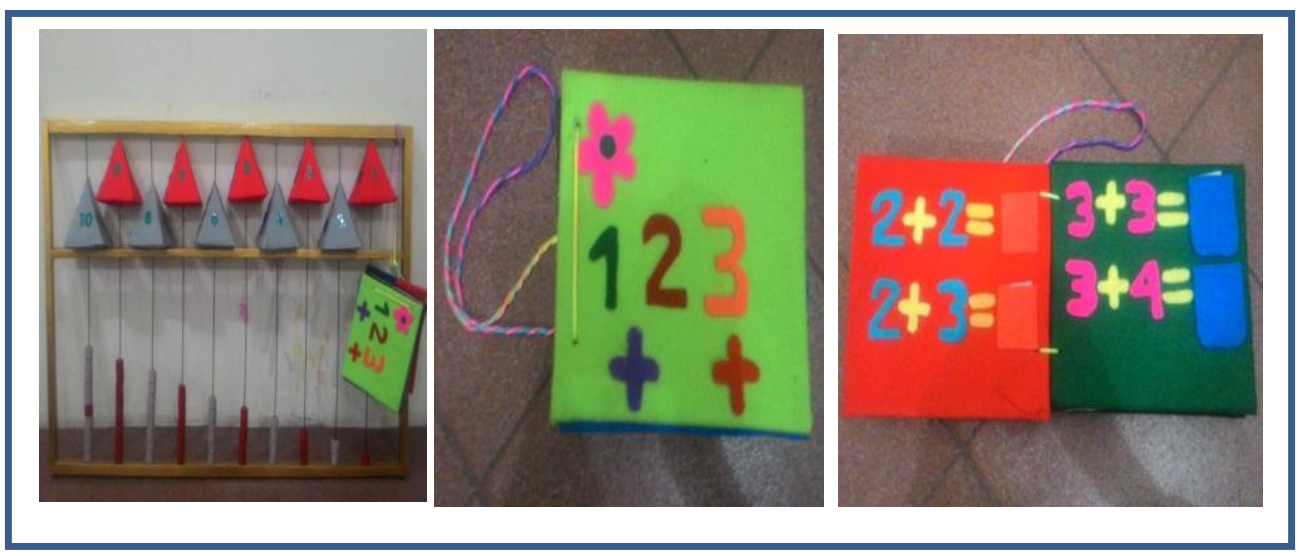

Gambar 22 APE Pengembangan Kognitif

\section{Aspek perkembangan :}

1. Kognitif

2. Bahasa

3. Motorik

\section{Alat dan bahan}

1. Gunting

2. Lem

3. Pisau cutter

4. Kain planel

5. Kayu

6. Besi

7. Baut

8. Tangkai sapu

9. Sticker

10. Karton 


\section{Media Pembelajaran Anak Usia Dini}

11. Benang wol

12. Gambar (angka dan buah)

\section{Proses pembuatan}

1. Buatlah bingkai sempoa dengan menggunakan kayu, berbentuk segi empat, lalu buat lah 10 buah besi di dalam bingkai.

2. Buatlah bangun ruang berbentuk segitiga. Dan buatlah biji-biji sempoa untuk masing-masing besi.

3. Setelah semuanya sudah selesai dibuat, bingkai, segitiga, dan biji sempoa diberi warna.

4. Susunlah biji sempoa pada bagian paling bawah dan segitiga di bagian atas.

5. Pada setiap sisi segitiga, buatlah pola lingkaran sebanyak bilangan yang ada.

6. Setelah bagian sempoa selesai dibuat, selanjutnya membuat buku untuk memandu anak mengerjakan soal-soal penjumlahan.

7. Pada bagian buku buatlah angka-angka penjumlahan dan kantong-kantong jawaban dan sisipkanlah kertas jawaban didalamnya.

\section{Cara Menggunakan}

1. Buka buku soal

2. Baca soal yang ada dengan arahan guru

3. Anak dimintak mencari jumlah yang tertera pada buku dengan menggunakan sempoa

4. Anak menghitung sempoa sesuai dengan jumlah

5. Anak memutar segi tiga pada sempoa sesuai jumlah jawaban soal

6. Lakukan dengan cara bergiliran setiap anak dengan bimbingan guru. 
Nama APE : Mobil Buah

Sasaran : Anak usia 3-5 tahun

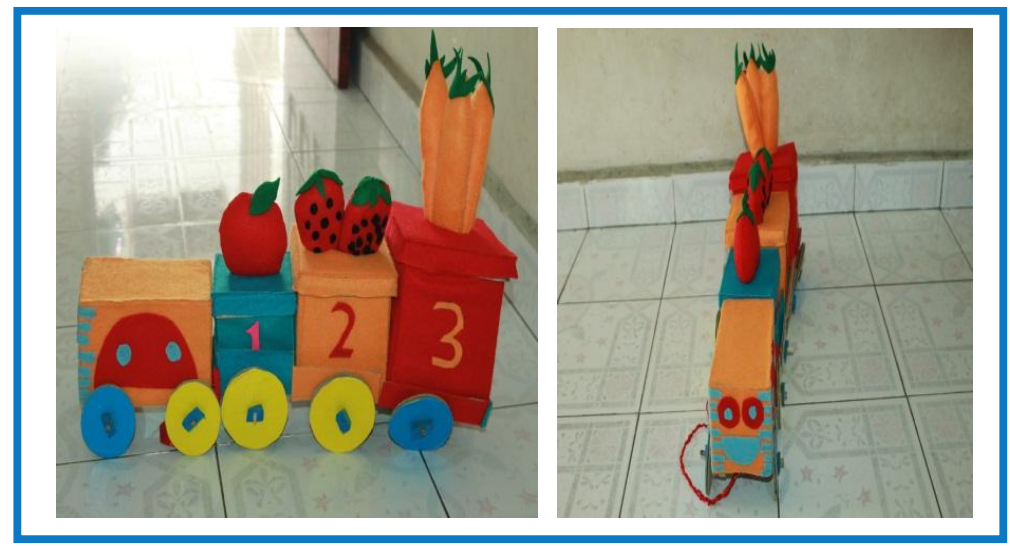

Gambar 23

APE Pengembangan Kognitf Untuk Usia 3-5 tahun

\section{Aspek perkembangan :}

1. Kognitif

2. Bahasa

3. Motorik

\section{Alat dan bahan:}

1. Gunting

2. Lem

3. Pisau cutter

4. Kain planel

5. Kertas trobos/ kardu bekas

6. Penggaris

\section{Proses pembuatan:}

1. Buatlah 4 buah kotak dari kertas trobos/ kardus bekas dengan ukuran berurutan.

2. Masing-masing kotak diberi tutup dan tiap tutup dilobangi untuk tempat boneka buah 
3. Lapisi kotak dengan kain planel

4. Masing-masing kotak ditempeli angka dan gambar

5. Buat 10 buah roda dari kertas trobos kain planel dan lapisi dengan

6. Buat boneka buah (1 untuk kotak 1, 2 untuk kotak 2, dan 3 untuk kotak 3) sesuai angka pada dinding kotak.

7. Rangkai kotak kotak menjadi mobil

8. Letakan boneka buah di atas tutup kotak sesuai dengan gambar dan angka pada dinding kotak

\section{Cara Menggunakan}

1. Anak dapat menarik mobil buah

2. Anak dapat menyebutkan nama buah

3. Anak dapat mengenal lambang bilangan yang ada pada dinding mobil atau kotak

4. Anak dapat menghitung boneka buah yang terdapat pada tutup kotak. 
c. Pengembangan Fisik-motorik

Nama Permainan : Lompat Gembira

Sasaran : Sasaran anak usia 3-6 tahun

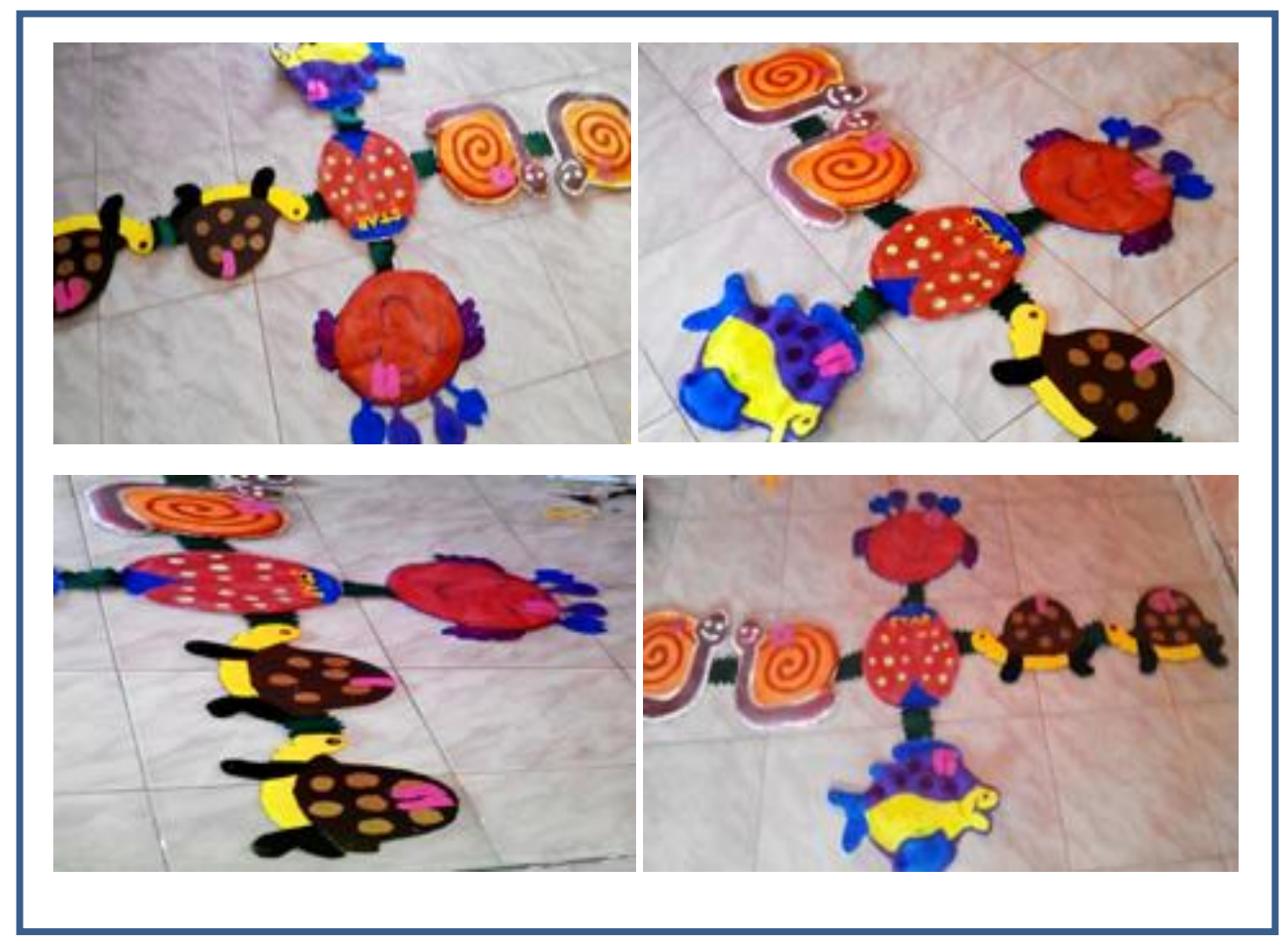

Gambar 24 APE Pengembangan Kinestetik

\section{Aspek yang dikembangkan :}

1. Aspek motorik kasar: karena anak melompat dengan menggunakan 2 kaki, dan mengerakkan seluruh tubuhmu.

2. Aspek kognitif: karena anak bisa membedakan berbagai macam warna, dan anak akan berfikir untuk menyeimbangkan antara lompatan dan irama yang di dengarnya.

3. Aspek bahasa: karena anak mendengarkan nyanyian, yang ada pada lagu. 
4. Aspek sosial emosional : anak mampu bergantian dengan temannya

\section{Alat dan bahan:}

1. Cuter

2. Gunting

3. Penggaris

4. Bahan polos warna putih

5. Kuas

6. Cat

7. Lem fox

8. Pola binatang

9. Benang wol

10. Busa

11. Serbuk kayu

12. Plastik

13. Kardus

14. Jarum jahit

15. Kain planel

\section{Cara pembuatan:}

1. Gunting kain dan kardus sesuai pola binatang yang telah ditentukan.

2. Warnai kain yang telah dibentuk sesuai pola dengan cat yang warnanya menarik

3. Tempelkan sebagain sisi kain pada kardus yang telah digunting sesuai pola.

4. Setelah itu masukan rasa pijakan pada setiap pola

5. Kemudian, semua sisi dijahit dengan benang wol agar terkesan rapi.

6. Setelah selesai pijakan tersebut disatukan dengan menggunakan kain planel. 
7. Setelah selesai, pijakan diberi tanda, mana bagian yang dipijak dengan 1 kaki dan dengan 2 kaki.

8. Kemudian permainan bisa dimainkan

\section{Cara menggunakannya:}

1. Bentangkan permainan di tempat yang luas, yang bisa membuat anak nyaman bermain.

2. Kemudian, guru memberi praktek cara permainan agar anak bisa memainkan permainan.

3. Setelah itu, pilih salah satu anak untuk memainkan ke depan, dengan bimbinggan ibu guru.

4. Anak bergerak dengan mengikuti suara musik, ketika musik berirama menyebutkan nama binatang (kepiting), maka anak melompat ke arah kepiting.

5. Anak akan melompat dengan 2 dan 1 kaki, sesuai dengan yang di tempelkan di gambar. 
88 Media Pembelajaran Anak Usia Dini 


\section{BAB V \\ MEDIA PENGEMBANGAN SENI ANAK USIA DINI}

\section{A. Pengertian Seni}

Seni adalah sebuah kegiatan yang tidak bisa terlepas dari manusia, karena seni senantiasa menyertai manusia mulai dari lahir sampai akhir hayat. Seni dalam kehidupan manusia adalah bagian yang tidak bisa dipisahkan, dia akan ada selalu dalam kehidupannya terutama pada anak usia dini. Seni yang lebih dikenal dengan rasa keindahan pada umumnya, yang melengkapi kesejahteraan hidup dan dinyatakan dalam pikiran menjadi bentuk yang dapat disalurkan dan dimiliki oleh setiap orang. Menurut Herbert Read (Hetty, 2006), bahwa "pengalaman rasa estetis" dapat diwujudkan dalam "penciptaan bentuk-bentuk yang menyenangkan". Seni menurut Tomas Mundro (Sumanto, 2006) adalah alat buatan manusia untuk menimbulkan efek-efek psikologis atas manusia lain yang melihatnya. Menurut Soedarso (Mikke Susanto, 2002) seni adalah karya manusia yang mengkomunikasikan pengalamanpengalaman batinnya, pengalaman batin tersebut disajikan secara indah sehingga merangsang timbulmya pengalaman batin pula pada manusia lain yang menghayatinya. Dalam pendidikan, seni dapat membantu pertumbuhan dan perkembangan anak, membantu perkembangan estetik, membantu menyempurnakan kehidupan, meningkatkan pertumbuhan fisik, mental, estetika, membina imajinasi kreatif, memberi sumbangan kearah pemecahan masalah, memberikana sumbangan perkembangan kepribadian. Sebagaimana yang dikemukan Tumurang, (2006) bahwa tujuan yang paling dekat dalam pendidikan seni anak adalah kepuasan anak-anak menggungkapkan perasaannya kedalam bentuk karya seni. Dari 
pendapat di atas nampaklah dengan adanya pembelajaran seni akan dapat memberikan pengalaman kreatif dan menyenangkan. Kegiatan berkesenian yang diberikan kepada anak akan dapat membuat anak menjadi kreatif, karena adanya penggunaan alat dan bahan yang memicu anak untuk ingin tahu dengan begitu akan dapat terjadi pengalaman edukatif pada diri anak. Sebagaimana yang dikemukakan oleh Soeharjo (dalam Sumanto, (2006) mengatakan sebagai pengalaman edukatif intinya adalah:

1) seni membantu pertumbuhan dan perkembangan anak,

2) seni membina perkembangan estetis,

3) seni bermanfaat mengembangkan bakat, dan

4) seni membantu menyempurnakan kehidupan.

Pengalaman edukatif yang terjadi dalam berkegiatan berkesenian pada anak usia dini tentu juga dapat mengembangkan kreativitas anak. sebagaimana Pakerti, (2005) menjelaskan bahwa potensi kreativitas dalam diri seorang anak dapat dikenali melalui kemampuan kreatifnya yaitu: 1) berfikir kratif, 2) kreativitas yang berkaitan dengan bakat seni yang alamia, 3) kreativitas dalam bermain. Jika pada usia dini seluruh potensi kreativitas dipupuk dan dimunkinkan berkembang maka secara beransur-ansur kreativitasnya meluas pada bidang-bidang lainnya.

Munandar, (2009) mengatakan kreativitas adalah interaksi antar individu dengan lingkungannya. Ini berati bahwa anak apa bila dihadapkan pada berbagai media seni seperti membuat kolase dari bahan alam, tentu anak akan merasa tertantang untuk menemukan pola-pola dalam menggunakan bahan tersebut untuk menjadi kaya seni. Hal ini akan membuat terjadinya kreativitas anak yang sudah tentu akan membuat anak untuk kreatif. Sumanto (2006) menjelaskan ada beberapa kondisi untuk meningkatkan kreativitas anak, yaitu: 1) sarana 
belajar dan bermain disediakan untuk meransang dorongan eksperimen dan eksplorasi, 2) lingkungan sekolah yang teratur, bersih, dan indah secara lansung akan mendorong kreativitas, 3) kemenarikan guru dalam mendidik dan memberikan motivasi, dan 4) peran masyarakat dan orang tua untuk mendukung kegiatan pendidikan. Selain itu Munandar, (1999) kreativitas adalah kemampuan untuk membuat kombinasi baru berdasarkan data, informasi, atau unsur-unsur yang ada. Dapat disimpulkan bahwa kreatifitas adalah kemampuan untuk menghasilkan gagasan baru, memecahkan masalah dan ide yang mempunyai maksud dan tujuan yang ditentukan.

Seni merupakan salah satu stimulasi sikap kreatif, artinya melibatkan seni dalam pembelajaran dapat mengaktifkan lebih banyak area-area dalam otak dari pada tanpa melibatkan seni. Para ahli saraf mengatakan bahwa bagian-bagian otak lebih banyak yang aktif akibat stimulasi kreatif daripada aktivitas yang tidak kreatif. Lebih dari itu area-area otak yang semula bertanggung jawab atas kognisi dan emosi turut terlibat aktif dalam memproses stimulasi yang kreatif. Keterlibatan dalam proses seni dapat meningkatkan spontanitas dan ekspresi diri, mengembangkan kontrol perhatian yang diperlukan untuk ketangguhan dalam menghadapi rasa takut, frustasi, dan kegagalan yang biasanya hadir ketika berusaha menciptakan karya (Suyadi, 2014). Oleh karena itu, seni perlu diajarkan di sekolah, bukan hanya bertujuan untuk menjadikan anak didik sebagai seniman, atau untuk meningkatkan kemampuan kognitif akademik tetapi memiliki tujuan lebih yaitu sebagai salah satu stimulis mengembangkan kapasitas otak yang hampir tidak terbatas.

Peranan kesenian di dalam pembelajaran di sekolah menurut Gray antara lain sebagai berikut: 


\section{Seni adalah dasar untuk berkomunikasi.}

Kesenian merupakan bentuk komunikasi manusia sebagaimana kata-kata membentuk kalimat/bahasa yang digunakan untuk menyampaikan perasaan maupun pikiran manusia. Kesenian mengajarkan suatu cara lain untuk berkomunikasi yaitu dengan memberikan jalan lain untuk mengungkapkan pikiran, emosi, ataupun perasaan anak. Seperti halnya di dalam seni tari, ungkapan gerak merupakan bahasa non verbal yang dikomunikasikan penari untuk mengutarakan apa yang dimaksudnya.

2. Seni membantu anak membangun kreatifitas dan bakat-bakat kreatifnya.

Kesenian memberikan ruang yang luas kepada anak untuk mengembangkan berpikir melalui imajinasi kreatif. Gray membuktikan dalam penelitiannya bahwa anak yang mempelajari kesenian pada umumnya memperlihatkan orsinalitas dan kreativitas.

3. Mempelajari seni membantu anak untuk belajar memahami makna. Pada proses kesenian diperoleh pengalaman langsung untuk belajar memahami makna yang tersirat dari suatu fenomena dan memahami pikiran dan perasaan orang lain. Melalui seni tari anak belajar untuk memahami simbol-simbol gerak yang diekspresikan oleh penari.

4. Mempelajari seni adalah jalan yang terbaik untuk memahami peradaban manusia. Kesenian merupakan bagian yang sangat penting dari peradaban manusia yang mencerminkan secara langsung siapa penciptapenciptanya dan latar belakang penciptaannya, dengan demikian kesenian memberikan komunikasi langsung dengan masa lalu dan mengantar pandangan mengenai masa depan. 


\section{Mempelajari seni membantu anak membangun} disiplin. Ketika anak terlibat berproses dalam sebuah cabang kesenian anak dilatih untuk menyadari bahwa mereka harus bekerja keras menyempurnakan keterampilan mereka. Dari para seniman profesional para anak dapat belajar sesuatu yang sangat berguna mengenai disiplin diri, baik untuk berlatih dalam mempelajari bidang kesenian yang telah dipilihnya maupun untuk manfaat lain dalam kehidupannya.

6. Mempelajari seni di sekolah membantu anak mempersiapkan masa depannya. Mempelajari kesenian di sekolah mengembangkan minat dan bakat anak untuk memilih kesenian sebagai minat karir mereka dimasa depan. Tidak hanya terbatas untuk menjadi seniman, tetapi keseninan memberikan peluang yang luas untuk bidang-bidang yang terkait seperti guru kesenian, penata kostum, penata panggung, penata lampu, event organizer, pengelola bidang pemasaran seni, dan peneliti yang terkait dengan seni.

7. Mempelajari seni membantu anak menumbuhkan penilaian artistik (Artistic Judgement). Artistic judgement banyak ditemukan dalam kehidupan seharihari, misalnya yang berkaitan dengan pemilihan warna, tekstur, bentuk, pola urutan gerakan, garis dan skala. Kesenian menjadi bagian integral dalam kehidupan sehari-hari, misalnya dalam: menyelaraskan warna pakaian, menggunakan bahasa tubuh ketika berkomunikasi dengan orang lain, menyajikan makanan yang menarik dengan memperhatikan tampilan tata saji meliputi penataan bentuk dan warna makanan. 


\section{Media Pembelajaran Anak Usia Dini}

\section{B. Pembelajaran Seni di PAUD/TK}

Pengembangan seni di taman kanak-kanak merupakan salah satu dari bidang pengembangan kemampuan dasar yang dipersiapkan oleh guru untuk meningkatkan kemampuan dan kreativitas anak sesuai dengan tahap perkembangannya. Ada 7 fungsi dari pengembangan seni (Direktorat Pembinaan Taman Kanak-kanak dan Sekolah Dasar, 2007), yaitu:

1. Melatih ketelitian dan kerapian anak.

2. Mengembangkan fantasi dan kreativitas anak.

3. Melatih motorik halus anak.

4. Memupuk pengamatan, pendengaran, dan daya cipta anak.

5. Mengembangkan perasaan estetika, dan menghargai hasil karya anak lain.

6. Mengembangkan imajinasi anak.

7. Mengenalkan cara mengekspresikan diri dengan menggunakan teknik yang telah dikuasai oleh anak.

Kompetensi dasar bidang pengembangan kemampuan dasar seni di taman kanak-kanak adalah sebagai berikut:

1. Untuk Kelompok A : Anak mampu mengekspresikan diri dengan menggunakan berbagai media/bahan dalam berkarya seni melalui kegiatan eksplorasi.

Kelompok A yaitu anak yang berusia 4-5 tahun, yang mana pada tahap perkembangan seni anak berada pada fase prabagan yaitu rentang usia 4- 7 tahun. Namun anak yang berada pada tahap ini perkembangan berkeseniannya masih banyak dipengaruhi oleh fase sebelumnya yaitu fase mencoreng yaitu rentang usia 2-4 tahun. Mencoreng yang terjadi pada kelompok A ini, mencoreng yang sudah terkendali dan bernama, karena anak yang berada pada usia ini sudah bisa memberi nama dan menceritakan dari hasil kreativitas seninya. Perkembangan seni juga dipengaruhi 
oleh perkembangan motorik halus anak yang sudah terkendali. Gerakan yang dilakukan oleh anak dalam berolah seni sudah terdapat koordinasi antara pikir dengan emosi dan kemampuan motoriknya. Maka obyek-obyek yang ada disekitarnya sudah menjadi kriteria dari hasil seninya. Kegiatan seni anak pada tahap ini dapat dikembangkan dengan menggambar dan berkreativitas dengan teknik basah maupun teknik kering, diantaranya adalah:

a. Menggambar dengan pensil, krayo dan cat air: seperti menggambar

b. Finger paint

c. Mencetak

d. Kerajinan kertas

e. Membatik

2. Untuk Kelompok B : Anak mampu mengekspresikan diri dan berkreasi dengan berbagai gagasan imajinasi dengan menggunakan berbagai media/bahan menjdi suatu karya seni.

C. Peraturan Menteri Pendidikan dan Kebudayaan Republik Indonesia Nomor 137 tahun 2014 Tentang Standar Nasional Pendidikan Anak Usia Dini

Standar isi tentang tingkat pencapaian perkembangan anak dalam lingkup perkembangan seni:

1. Usia 3-4 tahun

a. Anak mampu membedakan antara bunyi dan suara

- Mengenali berbagai macam suara dari kendaraan

- Meminta untuk mendengarkan lagu favorit secara berulang

b. Tertarik dengan kegiatan musik, gerakan orang, hewan maupun tumbuhan 
- Mendengarkan atau menyanyikan lagu

- Menggerakkan tubuh sesuai irama

- Bertepuk tangan sesuai irama musik

- Meniru aktivitas orang baik secara langsung maupun melalui media, (misal: cara minum / cara biacara / perilaku seperti ibu)

- Bertepuk tangan dengan pola yang berirama (misalnya bertepuk tagan sambil mengikuti irama nyanyian

c. Tertarik dengan kegiatan atau karya seni

- Menggambar dengan menggunakan media (cat air, spidol, alat menggambar) dan cara (seperti finger painting, cat air, dan lain-lain)

- Membentuk sesuatu dengan plastisin/playdoh

- Mengamati dan membedakan benda sekitarnya yang ada di luar rumah

2. Usia 4-5 tahun

a. Anak mampu menikmati berbagai macam alunan lagu atau suara

- Senang mendengarkan berbagai macam musik atau lagu kesukaannya

- Musik/instrumen/benda yang dapat membentuk irama yang teratur.

b. Tertarik dengan kegiatan seni

- Memilih jenis lagu yang disukai

- Bernyanyi sendiri

- Menggunakan imajinasi untuk mencerminkan perasaan dalam sebuah peran

- Membedakan peran fantasi dan kenyataan

- Menggunakan dialog, perilaku, dan berbagai materi dalam menceritakan suatu cerita 
- Mengekspresikan gerakan dengan irama yang bervariasi

- Menggambar objek disekitarnya

- Membentuk berdasarkan objek yang dilihatnya (misalnya dengan plastisin, dan tanah liat).

- Mendiskripsikan sesuatu (seperti binatang) dengan objek ekspresif yang berirama (contoh, anak menceritakan gajah dengan gerak dan mimik tertentu)

3. Usia 5-6 tahun

a. Anak mampu menikmati berbagai macam alunan lagu atau suara

- Anak bersenandung atau bernyanyi sambil mengerjakan sesuatu

- Memainkan alat musik/instrumen/benda bersama teman

b. Tertarik dengan kegiatan seni

- Menyanyikan lagu dengan sikap yang benar

- Menggunakan berbagai macam alat musik tradisional maupun alat musik lain untuk menirukan suatu irama atau lagu tertentu

- Bermain drama sederhana

- Menggambar berbagai macam bentuk yang beragam

- Melukis dengan berbagai cara dan objek

- Membuat karya seperti bentuk sesungguhnya dengan berbagai bahan (kertas, plastisin/playdoh, dan lain-lain).

\section{Implementasi Pendidikan Seni Anak Usia Dini}

Pelaksanaan pendidikan seni di PAUD/TK adalah merupakan proses belajar yang dilakukan anak dengan 


\section{Media Pembelajaran Anak Usia Dini}

mendapatkan pengalaman baru. Pengalaman yang diperoleh anak ketika melakukan kegiatan seni memperoleh pengetahuan sebagai hasil pengalaman lansung dari kegiatan tersebut tersebut.

Sementara pekembangan dewasa ini, masyarakat telah merasakan akan pentingnya suatu pendidikan di PAUD dalam membantu perkembangan seluruh aspek kepribadian anak. Menurut kami anak -anak yang mendapatkan pendidikan di PAUD tidak sama halnya dengan anak yang tidak mendapatkan pendidikan di PAUD. Karena kebanyakan anak yang memperoleh pendidikan di PAUD lebih mudah menerima pendidikan lebih lanjut ketimbang anak yang tidak memperoleh pendidikan di PAUD. PAUD sangatlah penting bagi anak, proses belajar mengajarnya menggunakan media.

Implementasi media pembelajaran terhadap pengembangan seni di PAUD bagi guru yaitu guru dapat menerapkan media seni di dalam proses pembelajaran di kelas, karena setiap proses pembelajaran di kelas setiap hari menggunakan media. Baik itu media visual maupun media audio visual. Maka untuk menerapkan seni disetiap pemebalajaran dapat dilakukan dengan mengunakan dan menerapkan seni tersebut yaitu:

\section{Boneka jari.}

Boneka jari ini adalah sebuah media pembelajaran dari pengembangan seni, media ini digunakan oleh guru pada saat proses belajar mengajar di dalam kelas. Media ini dapat menstimulasi berbagai aspek perkembangan anak. Melalui media ini anak akan dapat menggunakan jarinya untuk bermain boneka. 


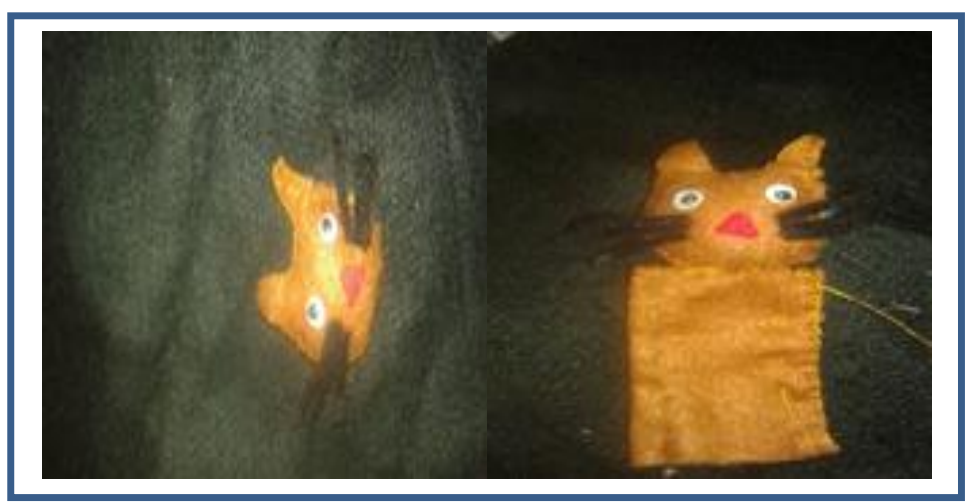

Gambar 25 Boneka Jari Dari Kain Planel

\section{Mencetak}

Prinsip mencetak adalah memindahkan gamabar ke atas kertas atau media lain dengan menggunakan acuan cetak yang terbuat dari berbagai jenis bahan misalnya: mencetak dengan anggota tubuh, mencetak dengan bahan alam dan mencetak dengan benda-benda temuan.

a. Mencetak dengan anggota tubuh

Mencetak dengan anggota tubuh dapat dilakukan dengan menggunakan jari, telapak tangan, dan kaki.

b. Mencetak dengan alam

Mencetak dengan bahan ini dapat dikelompokan atas tiga yaitu:

1) cetak asli, yaitu cetakan yang diper-gunakan asli yang terdapat di alam seperti daun, ranting, buah dan sebagainya.

2) cetak irisan, yaitu cetakan yang dibuat dari bahan alam tapi sudah dilakukan pemotongan atau diiris seperti: pelepah pisang, batang talas, buah belimbing dan sebagainya.

3) cetak stempel yaitu cetakan dibuat dengan membuat stenpel dari bahan alam seperti wortel, 
kentang, ketela rambat dan sebagainya. Namun untuk anak usia dini yang lazim digunakan adalah cetak asli

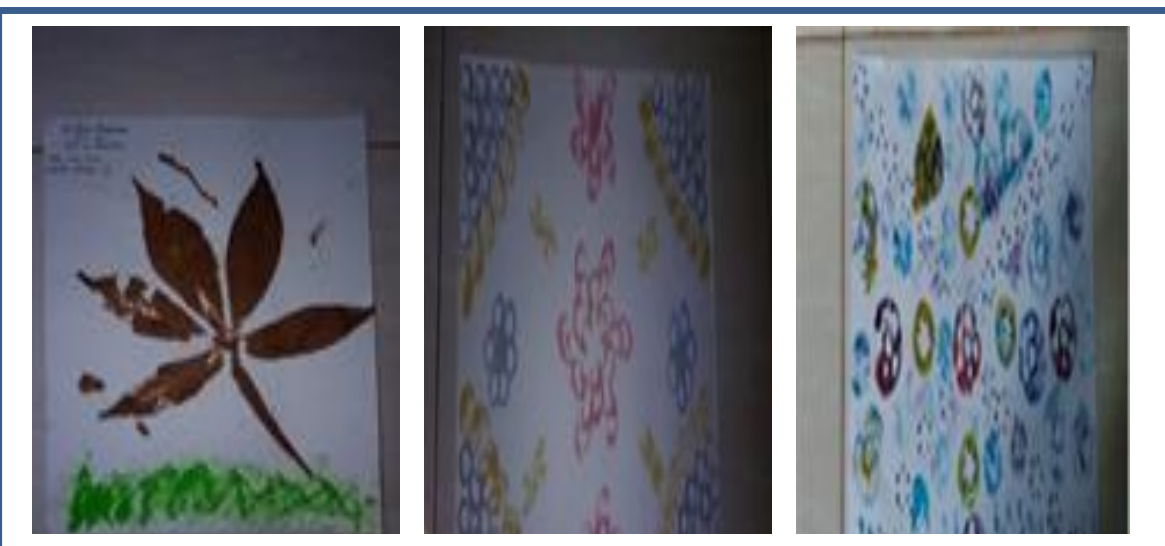

A

B

C

Gambar: 5.2

Contoh 26 hasil cetakan dengan teknik cetak asli, irisan, stempel

A.Cetakan asli, B. Cetak Irisan, C. Cetak stempel

c. Mencetak dengan benda-benda disekitar

Mencetak dengan benda-benda disekitar maksudnya adalah mencetak dengan benda-benda yang ada disekitar anak seperti, tutup botol. Pandat botol, pantat gelas, sendok dan sebagainya. 


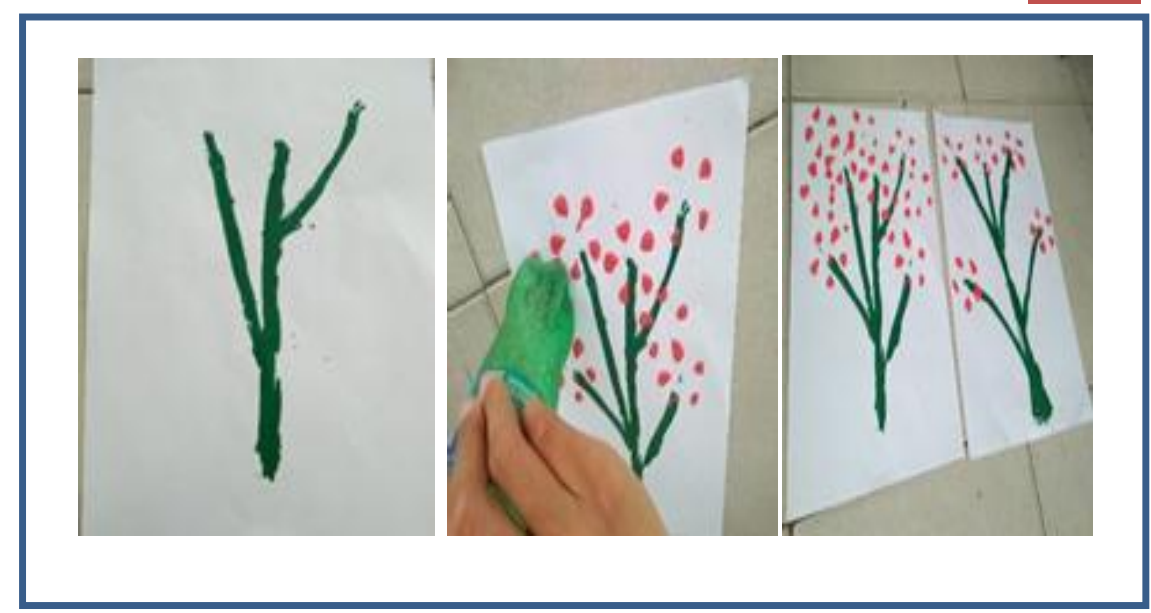

Gambar 27

Contoh mencetak dengan pantat botol

\section{Clay}

Clay adalah media seni yang dibuat oleh guru untuk mengembangkan aspek seni dan motorik halus yang dimiliki anak. Dalam motorik halus anak dapat membentuk berbagai macam bentuk yang telah dicontohkan oleh guru atau anak sendiri yang membentuk dengan imajinasinya sendiri dan aspek seninya anak bisa menggabungkan warna yang sesuai. Clay dapat dibuat dengan bahan-bahan dan cara cara tertentu. 


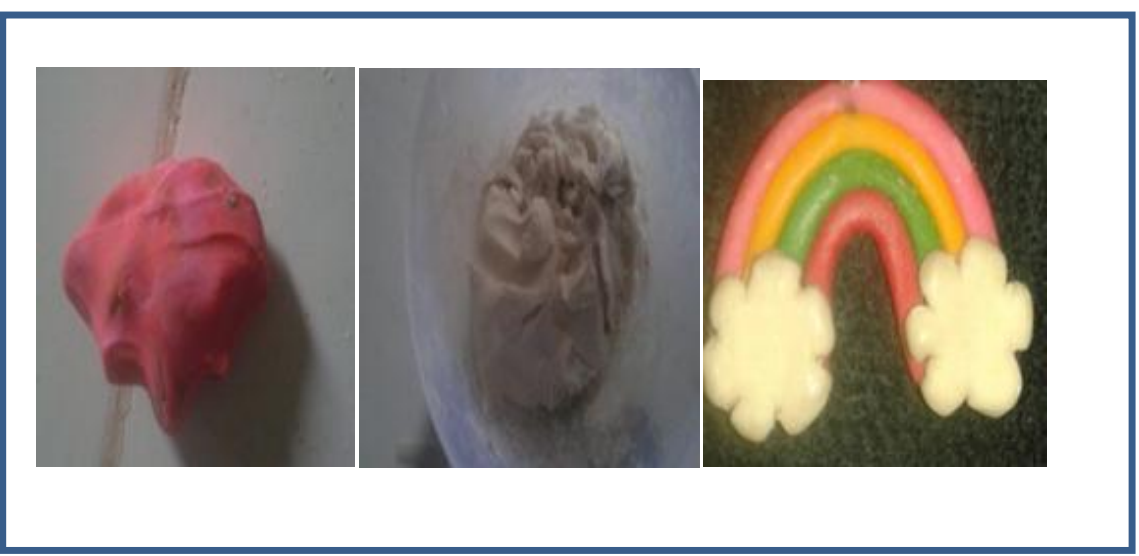

Gambar 28

Contoh clay untuk media seni

\section{Bahan:}

Tepung Terigu 70 gr, Tepung Beras 70 gr, Tepung Tapioka 70 gr, Lem putih 800gr, dan Pewarna Makanan.

Alat: Baskom

\section{Cara Membuat:}

1. Campurkan semua tepung sesuai dengan takaran ke dalam baskom.

2. Setelah itu campurkan lem putih sampai adonan tepung sampai halus.

3. Adonan clay siap diberi warna yang diinginkan.

4. Adonan clay siap untuk digunakan

\section{Cara mengunakannya:}

1. Sebelum memperlihatkan contoh kepada anak, guru terlebih dahulu memberikan adonan clay yang warnanya berbeda setiap masing-masing anak.

2. Selanjutnya guru memberikan aturan dalam kegiatan. 
3. Setelah itu guru memberi perintah untuk membentuk kelompok yang adonan clay yang berbeda warnanya.

4. Guru menyuruh anak untuk saling berbagi adonana clay yang berbeda, jadi setiap anak mempunyai semua warna.

5. Guru memperlihatkan contoh clay yang sudah jadi.

6. Selanjutnya guru menyuruh anak membuat apa yang telah diperlihatkan

Oleh guru

\section{Krincing}

Krincing adalah alat musik yang digunakan untuk mengembangkan aspek seni yaitu anak bisa mengiringi alat musik dengan lagu. Di dalam media ini anak dapat menggunakan alat musik sederhana

Nama Media : Alat musik dari tutup botol

Sasaran : Kelompok usia 5-6 tahun

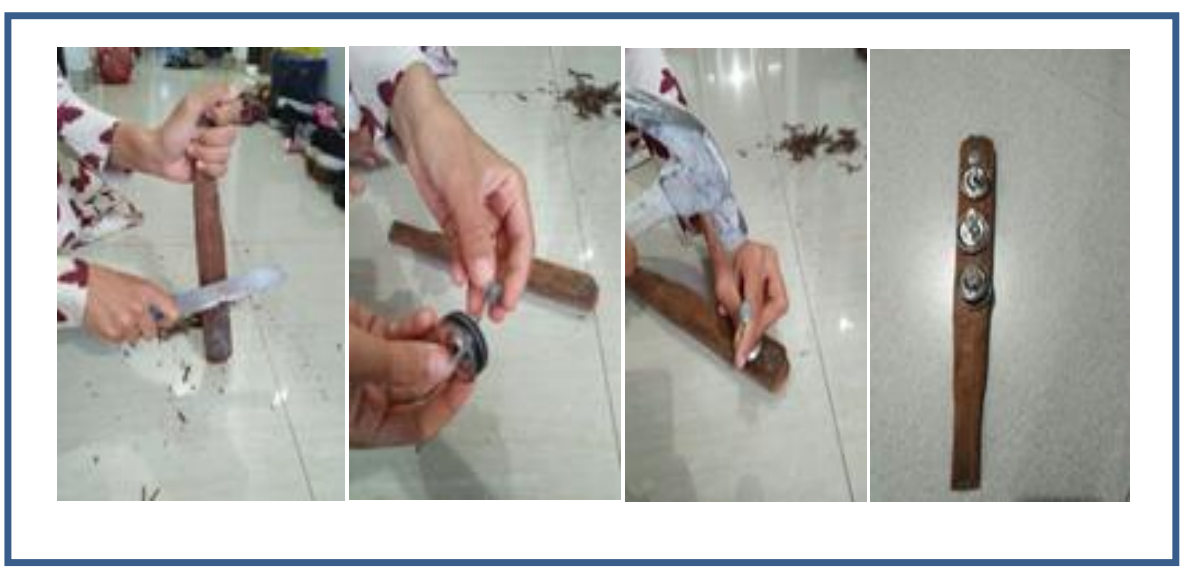

Gambar 29

Pembuatan Krincing dari Tutup Botol 


\section{Kemampuan yang dikembangkan :}

1. Nilai Agama dan Moral: Mengucapkan doa sebelum dan/sesudah melakukan sesuatu. Membiasakan diri berperilaku baik.

2. Fisik-motorik: Memanfaatkan alat permainan di luar kelas. Mengekspresikan diri dengan berkarya seni menggunakan berbagai media.

3. Kognitif: Mengenal benda-benda berdasarkan fungsi (pisau untuk memotong, pensil untuk menulis).

4. Bahasa: Mengerti dua perintah yang diberikan bersamaan. Menyatakan alasan terhadap sesuatu yang diinginkan atau ketidaksetujuan. Mengetahui konsep banyak sedikit.

5. Sosial-emosional: Menunjukkan sikap mandiri dalam memilih kegiatan.

Memiliki sikap gigih. Menaati aturan yang berlaku dalam suatu permainan.

6. Seni: Memainkan alat musik/instrumen/benda yang dapat membentuk irama yang teratur. Bernyanyi sendiri.

Bahan :Tutup botol limun, Paku, Kayu, dan Cat.

Alat : Palu, Pisau, dan Kuas.

\section{Cara Membuat:}

1. Sediakan kayu sepanjang $25 \mathrm{~cm}$.

2. Amplas kayu sampai ia halus agar aman untuk digunakan.

3. Buatlah gagang untuk pegangan

4. Tutup botol yang telah dilobangi dimasukkan ke dalam paku kemudian pakukan ke kayu. 
5. Lakukan sebanyak 3 kali dengan memberi jarak antara satu dengan yang lainnya.

6. Kemudian cat hingga merata agar terlihat menarik.

\section{Cara Menggunakan:}

1. Pertama-tama guru menceritakan tentang alat musik yang telah dibuat.

2. Kemudian guru menunjukkan alat musik tersebut.

3. Lalu guru mengajak anak untuk memainkan alat musik secara bergantian dan bernyanyi.

4. Bagi anak yang tertib dan bagus cara memainkan serta menyanyikan diberikan reward oleh guru berupa bintang yang terbuat dari kertas. 
106 Media Pembelajaran Anak Usia Dini 


\section{DAFTAR PUSTAKA}

Arsyad, Azhar . 2014. Media Pembelajaran. Jakarta:Raja Grafindo Persada.

Asnawir Basyirudddin Usman. 2002. Media Pembelajaran. Jakarta:Ciputat.

Basuki Wibawa dan Farida Mukti. 1993. Media Pengajaran. Jakarta: Dikti

Dadan Supriatna. 2009. Pengenalan Media Pembelajaran. Jakarta:Pusat Pengembangan dan Pemberdayaan Pendidik dan Tenaga Pendidik Taman Kanak-Kanak dan Pendidik Luar Sekolah.

Depdiknas. 2007. Modul Pembuatan dan Penggunaan APE Anak Usia 3-6 Tahun. Jakarta:Dirjen Pendidikan Luar Sekolah Direktorat PAUD.

Direktorat Pembinaan TK dan SD. 2007. Pedoman Pembelajaran Bidang Pengembangan Bahasa Di Taman Kanak-Kanak. Jakarta:Kemendiknas.

Djamaris. 1993. Menggali Khasanah Sastra Melayu Klasik. Jakarta:Balai Pustaka.

George S. Morrison. 2012. Dasar-dasar Pendidikan Anak Usia Dini (PAUD). Jakarta:PT Indeks.

Guslinda. 2017. Kerajinan Tenun Songket Melayu Riau Untuk Pelestarian Kearifan Lokal. Jurnal Figur Vol. 02. Nomor 01. Ikatan Alumi PGSD.

Hadi Susanto. 2018. Pengertian Pembelajaran Berbasis Budaya. diambil dari htt/bangawanabiyasa word press.com /2018/01/ pembelajaran berbasis budaya diakses tanggal 1 Agustus 2018. 
Hairudin dkk,. 2008. Bahan Ajar Cetak Pembelajaran Bahasa Indonesia. Jakarta. Dirjen Pendidikan Tinggi Departemen Pendididkan Nasional.

Hajar Pamadhi dkk. 2010. Seni Keterampilan Anak. Jakarta:Universitas Terbuka.

Hartono. 2012. Pembelajaran Tari AUD. Semarang:Unnes Press.

Heinich, Robert. 1982. Michael Molenda, and James D. Russel, Instructional Media and The New Technologies of Instruction, John Wiley \& Son, New York.

Hendrik, Makmur, dkk. 2005. Tegak Menjaga Tuah, Duduk Memelihara Marwah, (Mengenal Sosok, Pikiran dan Penggabdian H. Tenas Effendy). Yogyakarta:Balai Kajian dan Pengembangan Budaya Melayu.

Hetty. J. Tumurang. 2006. Pembelajaran Kreativitas Anak Sekolah Dasar. Jakarta:Departemen Pendidikan Nasional Direktorat Jenderal Pendidikan Tinggi Direktorat Ketenagaan.

Indriana, Dina. 2011. Ragam Alat Bantu Media Pembelajaran. Yogyakarta. Diva Press.

Jalinus, Nizwardi dan Ambiayar. 2016. Media dan Sumber Pembelajaran. Jakarta: Kencana.

Kamus Bahasa Indonesia. 2003. Kamus Bahasa Indonesia Edisi Ketiga. Jakarta: Balai Pustaka.

Kemdikbud. 2015. Pedoman Pengembangan Tema Pembelajaran PAUD. Jakarta:Dirjen PAUD dan Masyarakat Direktorat PAUD.

Kemdikbud. 2015. Kurikulum PAUD Apa, Mengapa, dan Bagaimana. Jakarta:Dirjen PAUD dan Pendidikan Masyarakat Direktorat Pembinaan PAUD.

Khadijah. 2015. Media Pembelajaran AUD. Medan:Perdana Publishing. 
2016. Pengembangan Kognitif Anak Usia Dini.

Medan:Perdana Publishing.

Manan, Imran 1989. Dasar-Dasar Pendidikan Sosial Budaya Pendidikan. Jakarta:Debdikbud Dirjen Dikti.

Munandar, Utami. 2009. Pengembangan Kreativitas Anak Berbakat. Jakarta. Rineka Cipta.

1999.Mengembangkan Bakat dan Kreativitas

Anak Sekolah. Jakarta.PT Gramedia Widiasarana.

Pamilu, Anik. 2007. Mengembangkan Kreativitas dan Kecerdasan Anak. Yogyakarta:Citra Media.

Pakerti, Widia dkk, 2005, Metode pengembangan seni, Jakarta, Universitas Terbuka

Poerwanto, Hari. 2000. Kebudayaan dan Lingkungan dalam Persfektif Antropologi. Yogyakarta:Pustaka pelajar.

Pusat Kurikulum. 2009. Pengembangan Pendidikan Budaya dan

Karakter Bangsa. Yogyakarta: Pedoman Sekolah.

Kurnia, Rita. 2014. Modul Media Pembelajaran Anak Usia Dini.

Pekanbaru: FKIP Universitas Riau.

Sadiman, Arief S. 2003. Media Pendidikan. Jakarta: Raja Grafindo Persada.

Slamet Suyanto. 2005. Pembelajaran untuk anak TK. Jakarta:Dirjen Dikti Direktorat Pembinaan Pendidikan Tenaga Kependidikan dan Tenaga Kependidikan.

Sanjaya, Wina. (2008). Perencanaan dan desain sistem pembelajaran. Jakarta: Kencana Prenada Media Group.

Sudjana, Nana dan Rivai, Ahmad. 2017. Media Pengajaran. Bandung:Sinar Baru Algensindo.

Sudjanta, Gobaqsodor, Tari, Wardi. 2010. Buku Pintar PAUD (dalam perspektf islam). Jogjakarta:Laksana.

Sudono, Anggani. 2000, Sumber Belajar dan Alat Permainan Untuk Anak Usia Dini, Jakarta, PT Grasindo. 
1995. Alat Permainan dan Sumber Belajar TK.

Jakarta: Depdikbud.

Suryanto, Slamet (2003). Konsep Dasar Pendidikan Anak Usia

Dini. Yogyakarta: Universitas Negeri Yogyakarta

Suyadi. 2014. Teori Pembelajaran Anak Usia Dini Dalam Kajian Neurosains. Bandung:PT Remaja Rosda Karya.

Trianto. 2011. Desain Pengembangan Pembelajaran Tematik Bagi Anak Usia Dini TK/RA dan Anak Usia Kelas Awal SD/ $R A$. Jakarta:Kencana.

Zaman, Badru, dkk. 2005. Media dan Sumber Belajar TK. Jakarta:Universitas Terbuka.

http://kunt34.blogspot.co.id/2011/10/pengembangan-seni-ditaman-kanak-kanak.html?m=1

http://www.kafebalita.com/

http://pondokibu.com/manfaat-bermain-puzzle-untuk-anak/

http://www.bimba-aiueo.com/manfaat-mewarnai-dan-

menggambar-bagi-anak/

https://id.wikipedia.org/wiki/Lingkungan, diakses tgl 18 agustus 2018. 


\section{RIWAYAT SINGKAT PENULIS I}

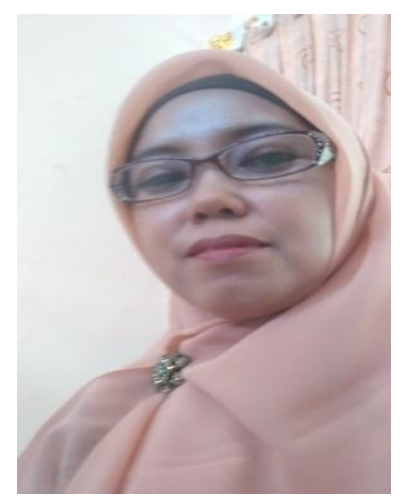

Penulis bernama lengkap Guslinda, S.Pd., M.Pd., lahir di Pasar Kambang Pesisir Selatan, 30 April 1974, Pendidikan dasar dan menengah dilalui di SD Impres Pasar Kambang, SMP Bakti Padang, dan SMA Muhammadiyah 5 Putri Padang, pendidikan tinggi di-peroleh di Pendidikan Seni Rupa dan Kerajinan IKIP Padang.

Setelah selesai Sarjana Melanjutkan ke Program Pendidikan IPS Pasca Sarjana Universitas Negeri Padang (2008-2010).

Penulis dosen tetap di PGSD FKIP Universitas Riau dan pengajar di PG PAUD SKIP Aisyiah Riau dari tahun 2007-2017. Sebagai pengasuh mata kuliah desain Interior, media dan APE. Untuk pengembangan dibidang PAUD tahun 2008 penulis mendirikan PAUD Raudhatul Jannah. Selain menggajar penulis juga aktif dalam pemberian pelatihan dibidang PAUD terutama untuk pengembangan media dan APE. Untuk penulisan buku, ini merupakan karya penulis yang pertama semoga dapat menjadi rujukan untuk pengembangan media dan APE bagi guru-guru TK, PAUD, dan RA. 
112 Media Pembelajaran Anak Usia Dini 


\section{RIWAYAT SINGKAT PENULIS II}

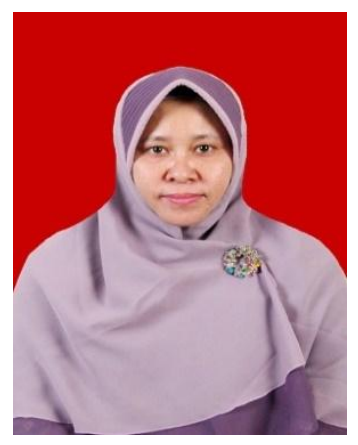

Rita Kurnia, Dr., M.Ed., Dra, lahir di Tanjung Pinang Kepulauan Riau tanggal 25 April 1967. Setelah tamat dari SMA Negeri 1 Padang tahun 1987, melanjutkan pendidikan (S1) pada Fakultas Keguruan Ilmu Pendidikan, Jurusan Pendidikan Bahasa dan Sastra Indonesia Universitas Bung Hatta Padang,

judul tesis "Perbedaan Penguasaan Kosakata Bahasa Indonesia Antara Murid Taman Kanak-Kanak yang Tingkat Sosial Ekonominya Berbeda" dan mendapat gelar Sarjana Tahun 1992. Tahun 2003-2005 melanjutkan pendidikan ke Master Pendidikan (S2) pada jurusan Pendidikan Prasekolah di Fakulti Pendidikan Universiti Kebangsaan Malaysia dengan judul tesis "Tujuan Pendidikan Prasekolah Antara Guru Prasekolah dan Orang Tua", memperoleh gelar Masters of Education. Tahun 2008-2012, kembali melanjutkan studi di jurusan Pendidikan Prasekolah (S3) di Fakulti Pendidikan Universiti Kebangsaan Malaysia judul disertasi "Kesediaan Membaca Kanak-Kanak Prasekolah" dan berhasil memperoleh gelar Doktor.

Bekerja sebagai dosen tetap pada Program Studi PGPAUD Fakultas Keguruan Ilmu Pendidikan Universitas Riau. Sejak tahun 2004 telah aktif melakukan penelitian, mengikuti seminar, dan menulis artikel pada jurnal penelitian. Karya ilmiah dalam bentuk buku yang pernah ditulis antara lain: (1) Metodologi Pengembangan Matematika AUD, 2009, Pekanbaru:Bintang Cendikia; (2) Evaluasi Pembelajaran AUD, 2010, Pekanbaru:Bintang Cendikia. Artikel pada jurnal 
penelitian antara lain: (1) Reading readiness amongst preschool children in Pekanbaru, ScienceDirect Procedia Social and Behavioral Sciences 9 (2010) 589-594; (2) The Differences of Vocabulary Mastery Based on Socio-Economic Levels in Early Childhood, ICTE 2017 di Fakultas Tarbiyah Sultan Syarif Kasim Universitas Islam Negeri Riau; (3) Tingkat Pemahaman Pendidik Paud Se-Provinsi Riau Mengenai Tujuan PAUD 2017 Jurnal Komuniti Pendidikan \& Kepelbagaian Budaya oleh Fakulti Pendidikan Universiti Kebangsaan Malaysia; (4) Perbandingan Matlamat Pendidikan Prasekolah Antara Guru Prasekolah dan Ibu Bapa Di Pekanbaru, 2007, Prosiding Seminar Internasional Pendidikan Serantau III; (5) Efektivitas Pemanfaatan APE Bahan Lokal Untuk Meningkatkan Kemampuan Bahasa Pada Anak Usia 5-6 Tahun, di Kecamatan Kampar Riau, Jurnal Educhild Prodi PG-PAUD FKIP Universitas Riau. Anggota Asosiasi PG PAUD Indonesia; dan Penelitian "Pengembangan Media Pembelajaran Untuk Kesiapan Membaca AUD dalam Bentuk Cerita Bergambar Cerita Rakyat Melayu, Di Siak Sri Indra Pura, Riau". Konsultan PAUD Yayasan Tunas Cahaya Kurnia Riau, (TK/KB/TPA). 
